\title{
Relating wellfield drawdown and water quality to aquifer sustainability - A method for assessing safe groundwater abstraction
}

Nørskov Gejl, Ryle; Løgstrup Bjerg, Poul; Henriksen, H. J.; Bitsch, K.; Troldborg, L.; Schullehner, J.; Rasmussen, J.; Rygaard, Martin

Published in:

Ecological Indicators

Link to article, DOI:

10.1016/j.ecolind.2019.105782

Publication date:

2020

Document Version

Peer reviewed version

Link back to DTU Orbit

Citation (APA):

Nørskov Gejl, R., Løgstrup Bjerg, P., Henriksen, H. J., Bitsch, K., Troldborg, L., Schullehner, J., Rasmussen, J., \& Rygaard, M. (2020). Relating wellfield drawdown and water quality to aquifer sustainability - A method for assessing safe groundwater abstraction. Ecological Indicators, 110, [105782].

https://doi.org/10.1016/j.ecolind.2019.105782

\section{General rights}

Copyright and moral rights for the publications made accessible in the public portal are retained by the authors and/or other copyright owners and it is a condition of accessing publications that users recognise and abide by the legal requirements associated with these rights.

- Users may download and print one copy of any publication from the public portal for the purpose of private study or research.

- You may not further distribute the material or use it for any profit-making activity or commercial gain

- You may freely distribute the URL identifying the publication in the public portal 


\section{Relating wellfield drawdown and water quality to aquifer}

\section{2 sustainability - a method for assessing safe groundwater}

3 abstraction

4

5 Authors: Gejl, R.N. ${ }^{1,2}$, Bjerg, P.L. ${ }^{1}$, Henriksen, H.J. ${ }^{3}$, Bitsch, K. ${ }^{2}$, Troldborg, L. ${ }^{3}$, Schullehner, J. ${ }^{3}$,

6 Rasmussen, J. ${ }^{2}$ and Rygaard, M. ${ }^{1}$

7 Institutions: DTU Environment ${ }^{1}, \mathrm{HOFOR} / \mathrm{S}^{2}$ and GEUS ${ }^{3}$

$8 \quad$ E-mail address: ryln@env.dtu.dk

9

\section{Keywords:}

- Environmental water requirements and flow requirements (EWR and EFR)

- Sustainable groundwater abstraction

- Groundwater impact assessment

- Water utility management

- EU Water Framework Directive

\section{Abstract}

Planning for sustainable groundwater abstraction requires realistic and reliable assessments of groundwater drawdown in aquifers as well as impacted groundwater-dependent terrestrial and aquatic ecosystems. Present-day impact assessments allocate water for the environment and ecosystems in the form of environmental groundwater requirements (EGWRs). However, securing sustainable groundwater abstraction also requires stable groundwater quality for consumers and receptors (e.g. streams and groundwater-dependent ecosystems). We suggest dividing EGWR into two parts, namely $E G W R_{\text {flow, }}$, related to impacts on surface water, and $E G W R_{w q}$, related to impacts on groundwater quality. We then propose a method for modelling maximum safe groundwater abstraction rates based on a relationship between water quality and piezometric heads. The method provides estimations of sustainable abstraction rates that secure stable water quality and maintain water security. Using hydrological modelling, we estimated spatially differentiated $E G W R_{w q}$, for Zealand, Denmark, based on three different conditioned drawdowns of 3, 6 and $9 \mathrm{~m}$. We found that 
depending on the boundaries and the different conditioned drawdown $E G W R_{w q}$ poses a $2.5-83 \%$ share of the groundwater recharge. We found that a redistribution of water abstraction would make $27 \mathrm{Mm}^{3}$ (million $\mathrm{m}^{3}$ ) available compared with actual abstraction, dependent on scale, while keeping within a conditioned drawdown of $3 \mathrm{~m}$. Our results demonstrate how conditioned drawdown can be implemented with the objectives of evaluating actual abstraction and securing stable water quality, hence comprising a step towards more reliable and relevant groundwater impact assessments.

\section{Introduction}

\subsection{Background/Motivation}

Freshwater is vital for ecosystems and is the base of human hygiene, food production and well-being (WWAP, 2016). In many places around the world, groundwater is essential for securing freshwater for ecosystems and humans (Zektser and Everett, 2004). To preserve stable groundwater resources for future generations, there is a growing interest for answers to essential questions like: How does our water abstraction affect the environment and the groundwater resource? How much water does nature need? And of what quality? These questions served as motivation for this study. In addition there is a pressing need to develop methods for water managers as The Water Framework Directive provides a structure for protecting streams, lakes, coastal waters and groundwater, in order to prevent further deterioration (European Union, 2006), but without describing a methodology or approach.

Methods for quantifying water stress, as well as what objectives they should serve, are discussed widely in the field internationally (e.g. Hoekstra, 2016; Nunez et al., 2016; Pfister et al., 2017). Evaluating water abstraction is often based on components of the water balance, e.g. AvailableWater-Remaining, AWaRe (Boulay et al., 2017), Withdrawal-To-Availability, WTA (Alcamo and Henrichs, 2002), Water Stress Index, WSl index (Pfister et al., 2009), Water Stress Indicator, WSI (Smakhtin et al., 2004) and groundwater footprint (Gleeson et al., 2012). Most assessments include an estimation of environmental water requirements (EWR), interpreted as the amount of water 
needed to sustain flow in streams and maintain wetlands etc. (International River Foundation, 2007). Water stress assessments focus generally on large-scale, e.g. global and regional, aquifers (Gleeson et al., 2012) with an average area of $50000 \mathrm{~km}^{2}$ and therefore give little consideration to local water abstraction challenges in smaller groundwater catchments (Hybel et al., 2015). The indicators mentioned above generally focus on surface water, which can result in misrepresentations of the groundwater impact (Gejl et al., 2018). Throughout Europe, 50\% of drinking water supplies relies on groundwater (Völker and Borchardt, 2019), and it is a significant resource for industrial and agricultural water demands (Jones and Anthony, 2011). This leads to a need for trustworthy indicators revealing groundwater stress that can secure relevant evaluations of resource availability. To overcome the focus on surface water and the large-scale perspective, we developed AGWaRe, the Available GroundWater Remaining, an indicator designed to assess groundwater impact and which can be applied on any scale (Gejl et al., 2018). However, AGWaRe does not consider potential impacts on groundwater quality that may be influenced by abstraction.

\subsection{Environmental groundwater requirements}

Internationally, there have been different approaches for ensuring and including the concept of Environmental Groundwater Requirements (EGWR). In Australia, for instance, focus has fallen on groundwater-dependent ecosystems and their water demands (Doeg et al., 2012), concentrating particularly on impacts on the shallow groundwater level. Another example, is in a study of the exploitation of global aquifers, EGWR were included to ensure environmental flows by setting $E G W R$ high enough to sustain $Q_{90}$ in streams, i.e. the monthly streamflow that was exceeded $90 \%$ of the time compared to a reference period (Gleeson and Wada, 2013). Such methods aim to limit the effects on river runoff and aquatic ecosystems. Danish water management plans relate abstraction to a percentage of the groundwater recharge (Henriksen et al., 2008), in order to screen for aquifer sustainability, based on a correlation between groundwater recharge (GWR) and aquifer health. A recent initiative involved evaluating how groundwater abstraction affects ecological flow indicators (Graeber et al., 2015), which was a positive step towards obtaining actual impacts on an endpoint 
81 level; however, these indicators only consider in-stream ecological flow requirements and

82 incorporate neither groundwater-surface water interactions nor groundwater quality.

83 Gejl et al. (2019) looked further into how groundwater abstraction influences groundwater quality.

84 However, the question of how much water should be reserved to prevent changes in groundwater

85 quality remains. To our knowledge, no one has defined EGWR in terms of sustaining groundwater-

86 dependent ecosystems, flow and water quality in aquifers. Inspired by environmental flow

87 requirements for river systems (International River Foundation, 2007), we define EGWR as "the

88 water from groundwater resources needed to sustain flows, preserve groundwater-dependent

89 ecosystems and maintain good groundwater quality". Through such a definition, EGWR includes the

90 adverse effects of groundwater abstraction on groundwater level and quality, including risks related

91 to increased vulnerability due to a lowered piezometric surface (Henriksen and Refsgaard, 2013).

92 Due to the duality in the intentions of $E G W R$, we suggest separating environmental water

93 requirements into:

$94 \quad E G W R_{\text {flow: }}$ Groundwater reserved to sustain base flow in streams and groundwater-

95 dependent ecosystems (surface water)

$E G W R_{w q}:$ Groundwater reserved to sustain aquifer health related to water quality affected

97 by water abstraction in the aquifer (groundwater)

Several publications address the flows needed to sustain groundwater-dependent ecosystems

(EGWR flow) (e.g. Graeber et al., 2015; Hoekstra et al., 2012; Smakhtin et al., 2004), and therefore we focus on $E G W R_{w q}$, which is critical for managing water supplies based on groundwater resources.

\section{$101 \quad 1.3$ Impacts from abstraction}

102 For a groundwater system, the water balance is a function of groundwater abstraction, the hydrogeological setting, precipitation and evapotranspiration, whilst for an aquifer, the water balance is comprised of three main components: 1) groundwater recharge (GWR), 2) in- and 
outflows over the aquifer boundaries (including abstraction) and 3) aquifer storage. Groundwater recharge diminishes lower down in the groundwater system, due to flows out of the groundwater compartments. Under natural conditions, groundwater systems are in a dynamic equilibrium where long-term average recharge equals long-term average discharge. Intense pumping will induce new recharge dynamics and impacts on the piezometric head and capture, causing drawdown, the depletion of springs and streamflow, loss of wetland, etc., and a new equilibrium may be established many years henceforth (Bredehoeft, 2002; Gleeson et al., 2012; Henriksen and Refsgaard, 2013); consequently, it is difficult to define consistent system boundaries for assessing the effects of groundwater abstraction. Drawdown can affect groundwater quality, e.g. pyrite oxidation, saltwater intrusion and the mobilisation of residual saltwater (Henriksen et al., 2008; Larsen and Postma, 1997; Postma et al., 2016).

In a study based on long-term data (1900-2015) of the piezometric head, abstraction and water quality for well fields abstracting water from confined aquifers around Copenhagen, we found that sulphate was the most sensitive parameter to drawdown and can be used to indicate overexploited aquifers (Gejl et al., 2019). For these well fields, we used sulphate concentrations as a proxy for evaluating sustainable abstraction in relation to the water quality of natural constituents. We found that from the mid-1980s and onwards, as water abstraction decreased and the piezometric head increased, sulphate concentrations decreased and stabilised. We suggested that water abstraction in this period (1985 - 2015) was sustainable from both a water quantity and a quality perspective. However, practical implementation in terms of managing water abstraction and any corresponding drawdown at various scales is still unresolved.

\subsection{Aim}

In the following, we demonstrate a method to assess safe abstraction from aquifers, based on the relationship between long-term drawdowns and potential groundwater quality impacts. The method aims to address the following questions: 
- How can we implement a groundwater drawdown constraint that sustains quality on multiple geographical scales over time?

- How much groundwater is available for abstraction without compromising aquifer water quality?

- What suitable indicators in groundwater impact assessments could be used to account for potential impacts on groundwater quality?

$136 \quad-\quad$ What drawdown represents local groundwater stress?

137 The method will assist groundwater-based water utilities in their decisions, as well as the use.

\section{Method}

142 2.1 Study area

143 The study was carried out for Zealand, Denmark, an area with decades-long pressure on groundwater resources caused by large water demands of Copenhagen, Denmark's largest city.

145 Zealand has an area of $7000 \mathrm{~km}^{2}$ and a population of 2.3 million, of which 1.6 million live in the 146 Greater Copenhagen area. This has forced water suppliers to abstract groundwater far from the city, 147 in competition with local water supplies in the northern and eastern parts of Zealand. The majority 148 of the groundwater on Zealand is currently abstracted from limestone aquifers (82\%), and the 149 elevations of the tops of these limestone aquifers vary (Figure 1). 


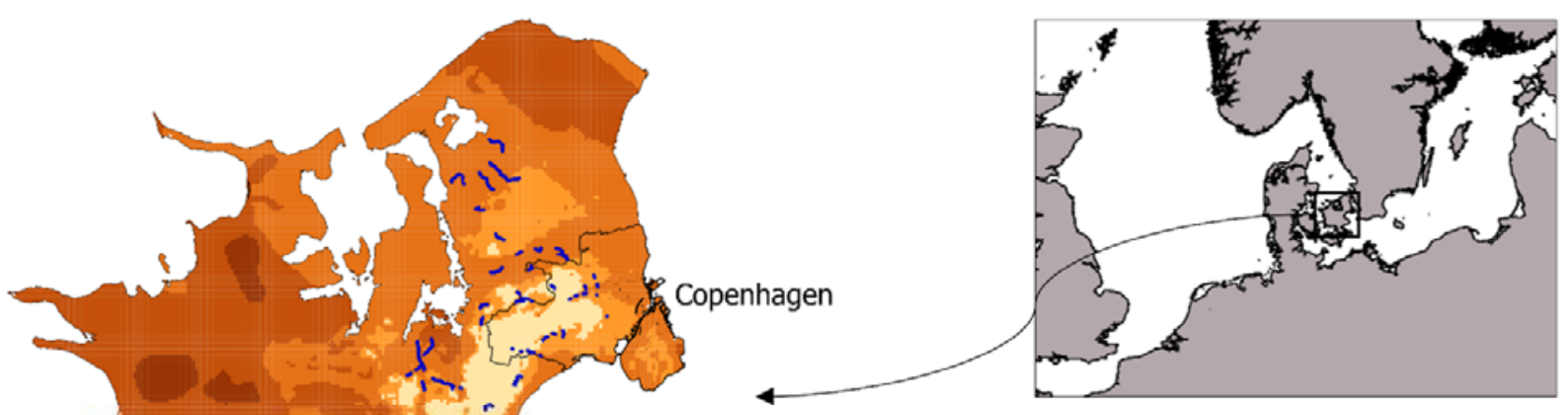

Elevation of top of limestone aquifers (masl)

- $<-100$

$=-100--50$

$=-50--10$

$=-10-0$

$>0$

-

Figure 1: The location of Copenhagen on the island of Zealand, and the elevations of the tops of the limestone aquifers, from which the majority of water is abstracted. The blue dotted lines represent the locations of HOFOR's well fields. The map was adapted from Højberg et al. (2015).

\subsection{A generic concept of defining $E G W R_{w q}$ from the maximum allowed drawdown}

Drawdown is defined as the difference in the modelled potentiometric head (termed the

'piezometric head' from now on) between pristine conditions (no abstraction) and actual abstraction:

$$
\text { Drawdown }=\text { head }_{\text {pristine }}-\text { head }_{\text {abstraction }}
$$

A conditioned drawdown is defined as a maximum allowed drawdown in the main aquifer from where the wells withdraw groundwater. From a conditioned drawdown, we can estimate the corresponding abstraction, which represents the maximum abstraction that is expected not to change water quality. We then define $E G W R_{w q}$ as the difference between the groundwater recharge under sustainable groundwater abstraction, $G W R_{\text {sus, }}$, and sustainable groundwater abstraction, $W U_{\text {sus, }}$, both defined from a conditioned drawdown:

$$
E G W R_{w q}=G W R_{\text {sus }}-W U_{\text {sus }}
$$


168 (Gejl et al., 2018), i.e. a groundwater impact indicator that evaluates the stress of the groundwater

169 resource compared to a reference. It is based on an absolute measure of how much water is

170 available, $A M D_{\text {aquifer }}$ (Availability-Minus-Demand), in an area and therefore gives an indication of

171 absolute water remaining for other uses. AGWaRe is a normalised parameter by relating the

$172 A M D_{\text {aquifer }}$ to a reference, $A M D_{\text {ref: }}$

$$
A G W a R e=\frac{A M D_{\text {ref }}}{A M D_{\text {aquifer }}}
$$

AGWaRe is cut-off below 0.1 and above 100, in line with the AWaRe methodology (Boulay et al., 2017). This implies that the greatest stress compares to 100 times the stress for the reference. $A M D_{\text {aquifer }}$ is availability-minus-demand in the aquifer:

$$
A M D_{\text {aquifer }}=G W R_{\text {sus }}-W U_{\text {actual }}-E G W R_{w q}
$$

where $W U_{\text {actual }}$ is water abstraction for actual conditions. $A M D_{\text {aquifer }}$ represents the difference between groundwater recharge for the conditioned drawdown, actual human needs and the water needed to sustain water quality. $A M D_{\text {ref }}$ is found with the same equation (4), but for a reference area. Thereby, AGWaRe relates local conditions to a reference condition (3). Replacing $E G W R_{w q}$ with (eq. 2), we obtain:

$$
A M D_{\text {aquifer }}=G W R_{\text {sus }}-W U_{\text {actual }}-\left(G W R_{\text {sus }}-W U_{\text {sus }}\right)=W U_{\text {sus }}-W U_{\text {actual }}
$$

and thereby $A M D_{\text {aquifer }}$ represents the additional amount of water that could be abstracted without compromising water quality in aquifers. If $A M D_{\text {aquifer }}$ is negative, actual water abstraction causes a greater drawdown than what one would expect to be sustainable and poses a risk of changing water quality. On the contrary, if $A M D_{\text {aquifer }}$ is positive, more water can be abstracted within the limits of the conditioned drawdown. With this definition, $A M D_{\text {qquifer }}$ can only be calculated for areas experiencing abstraction (Eq. 5), which is in accordance with our objective of evaluating impacts related to groundwater abstraction. 
For an assessment of the distance to sustainable conditions (DSC), we also define the measure:

$$
D S C=\frac{W U_{\text {sus }}}{\left(W U_{\text {sus }}-W U_{\text {actual }}\right)}
$$

where DSC is cut-off above 100 (negative values are given 100) and where 100 indicates that the actual water abstraction is close to or exceeds the sustainable limit.

\subsection{Groundwater model and setup}

196 We modelled the components of the water balance and the piezometric head, using the hydrological 197 model for Zealand (a submodel of the national Danish hydrological model (DK-model), Højberg et al., 198 2015). The DK-model was constructed for assessing large-scale water balances and the interaction between groundwater and surface water on a regional scale (Højberg et al., 2013). The Zealand model simulates the fluxes to and from the groundwater resource and consists of 12 hydrostratigraphics, constituting the 12 calculation layers in the saturated zone. The DK-model includes daily precipitation, temperature and evapotranspiration (GEUS, 2009), and the results were validated against runoff measurements from more than 200 stream-gauging stations and more than 100,000 piezometric head observations from groundwater wells (Henriksen and Sonnenborg, 2003; Højberg et al., 2015). Groundwater abstraction was based on data from the national database JUPITER, which contains annual water statistics for utilities, industrial water use and modelsimulated agricultural abstractions (Henriksen and Sonnenborg, 2003; Højberg et al., 2015). The geological model is discretised in a $100 \times 100 \mathrm{~m}$ grid using layers and lenses for geological structures, whereas the hydrological model is discretised for a 500 × 500 m grid (Højberg et al., 2015; Klint et al.,

210 2013). The model simulates an equivalent porous medium without any fracture flow, and we believe

211 this assumption is valid despite limestone being a fractured medium, since the analysed

212 groundwater drawdown represents long-term equilibrium conditions (Aisopou et al., 2014). 


\subsection{Conditioned drawdown}

214 To model groundwater abstraction corresponding to a conditioned drawdown, we applied fixed 215 head boundary conditions, correspondingly modelling a grid cell where water is drained until it 216 reaches a certain piezometric head. The drained water constitutes the maximum water abstraction 217 within the constrained drawdown. The fixed head was applied to all 1751 abstraction grid cells on 218 Zealand, and because well screens can extend across several layers, the drawdown was conditioned in seven confined layers, with limestone aquifers, sandy aquifers and aquitard layers covering them

220 (the bottom seven layers in the model). The baseline scenario for our analysis refers to average actual abstraction for 2003 to 2012, which is $157 \mathrm{Mm}^{3} /$ year (million $\mathrm{m}^{3} /$ year) for the groundwater system and $112 \mathrm{Mm}^{3} /$ year from confined aquifers.

In the simulations, drawdown was calculated as the mean difference in the piezometric head for each grid cell between pristine conditions (zero abstraction) and each scenario. Simulations were constrained as follows:

- We included water abstraction by public water utilities in the analysis, but we excluded agricultural and industrial wells, because they mainly abstract water from shallow, unconfined aquifers.

- To avoid saltwater intrusion, drawdowns were constrained to avoid piezometric heads below sea level.

- To avoid changing confined aquifers to unconfined, drawdowns were constrained to avoid

\subsubsection{Scale}

234 We wanted to include a consistent and relevant demarcation of groundwater bodies; however, this was a challenge because of the complexity and inconsistency of groundwater demarcations. Several well-defined scales exist for surface water where topography provides a simple and consistent demarcation of catchment areas. River basin, river catchment and sub- areas are all established 
terms used in Danish River Basin Management plans (e.g. SVANA, 2016). For groundwater, however,

239 there are no clear or stable demarcations on the local scale. Furthermore, the groundwater

240 catchment area changes in line with abstraction and is therefore constant in neither time nor space.

241 In Denmark, groundwater bodies (as referred to in the EU Water Framework Directive) are based

242 partly on an aquifer delineation within the Danish geological model (GEUS, 2009) and partly by

243 considering administrative and monitoring purposes (Troldborg et al., 2014). Groundwater bodies

244 may merge aquifers located far apart, or divide continuous aquifers. Such mixed physical and

245 administrative delineation impairs comparative assessments of groundwater impacts, and so with no

246 obvious choice in terms of demarcation, we decided to explore five scales (Table 1).

Table 1: Five scale definitions for groundwater assessment and the associated applied scales with area range,

248 advantages and disadvantages.

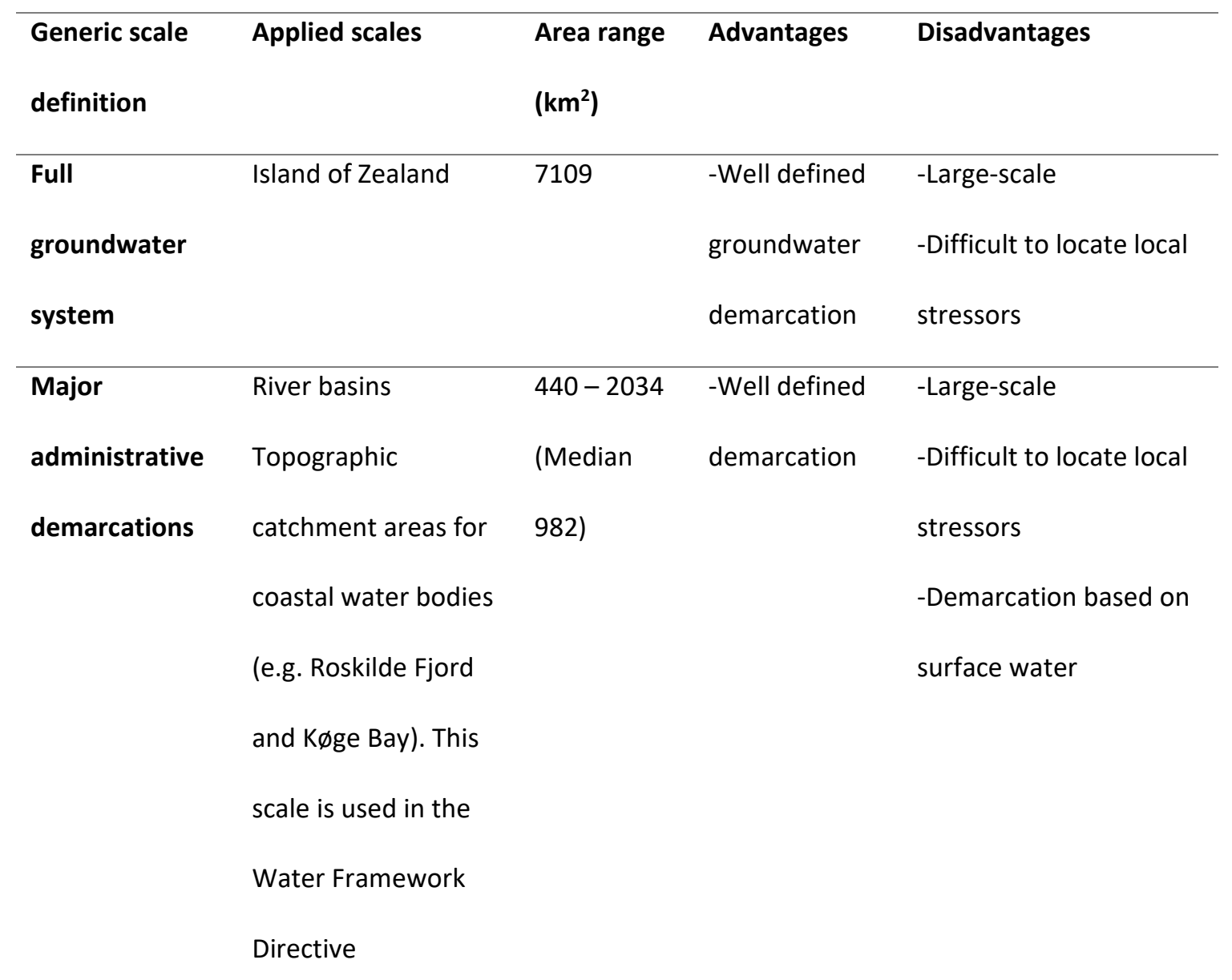




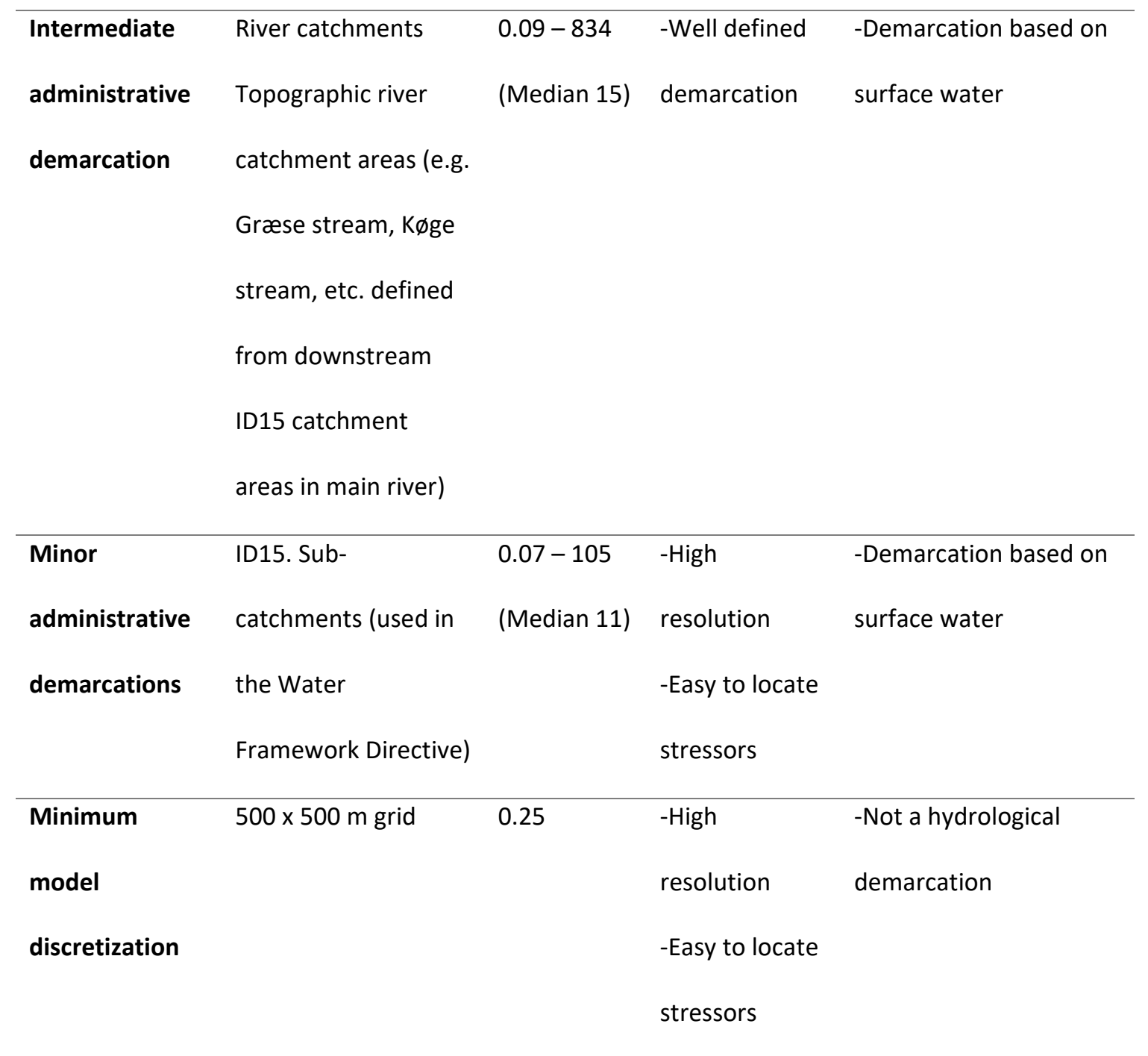




\subsubsection{Defining conditioned drawdown}

250 We considered three different conditioned drawdowns of 3, 6 and $9 \mathrm{~m}$, as our earlier study of the connection between drawdown and changes in water quality parameters (Gejl et al. 2019) suggested

252 a sustainable drawdown for Zealand between 3 and $9 \mathrm{~m}$. For a discussion on the drawdown range, see Supporting Information (SI. 1). Following a conservative approach, we focused on a drawdown of showed that some aquifers were less vulnerable and could allow for a larger drawdown, without compromising water quality.

\subsubsection{Defining groundwater recharge}

258

259

260

261

262

263

264

We considered groundwater recharge as the vertical flow over a boundary and explored three definitions (Figure 2): 1) GWR inf is the flow from an unsaturated to a saturated zone (also called 'net

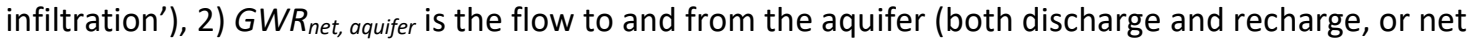
recharge) and 3) GWR aquifer is recharge to the aquifer.

Groundwater recharge is influenced by several factors such as pressure, hydraulic conductivity, depth to aquifer, artificial drainage, etc., and there can be several delineations, all of which would result in different quantifications of this process. Thorling et al. (2015a) used $G W R_{\text {inf }}$ as a

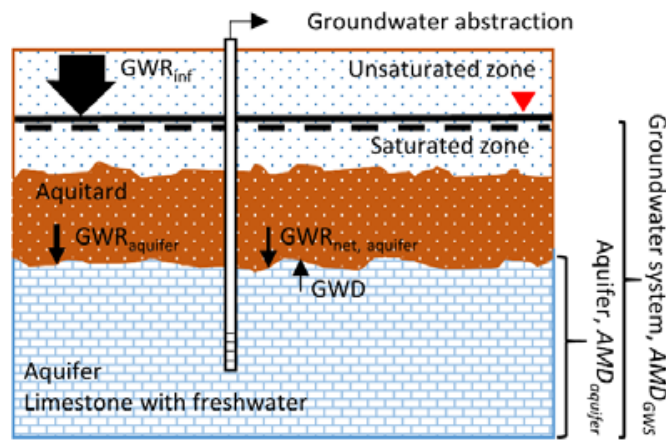

Figure 2: Conceptual figure of delineations of groundwater recharge: 1) GWRinf, the downward flow from an unsaturated zone to a saturated zone, 2) GWR aquifer groundwater recharge to the aquifer or 3) GWR net, aquifer the net groundwater recharge. GWD is groundwater discharge. The thickness of the arrows reflects the quantities of groundwater recharge in relative terms. AMD (availability-minus-demand) differs according to the boundaries. 
265 demarcation, but it does not actually indicate groundwater availability in deeper parts of the

266 groundwater system, where the majority of abstraction occurs. Since the corresponding study (Gejl

267 et al., 2019) of the correlation between drawdown and water quality focused on confined aquifers,

268 we suggest $G W R_{\text {net, aquifer }}$ as the appropriate measure of groundwater recharge. GWR $R_{\text {aquifer }}$ refer to

269 water flowing both upward and downward and is therefore smaller that GWR $R_{\text {net, aquifer }}$ that only refer

270 to the recharge of the aquifer (downward). As expected, the quantities of the different delineations

271 of groundwater recharge show that $G W R_{\text {inf }}$ is larger than $G W R_{\text {aquifer }}$ and $G W R_{\text {net, aquifer }}$ (Figure 3). 
a) $\mathrm{GWR}_{\text {inf }}$ (positive downwards)

b) GWR net, aquifer (positive

downwards)

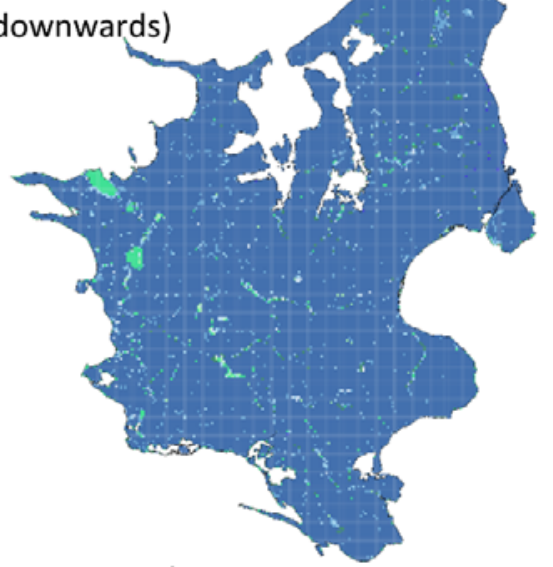

c) GWR $R_{\text {aquifer }}$

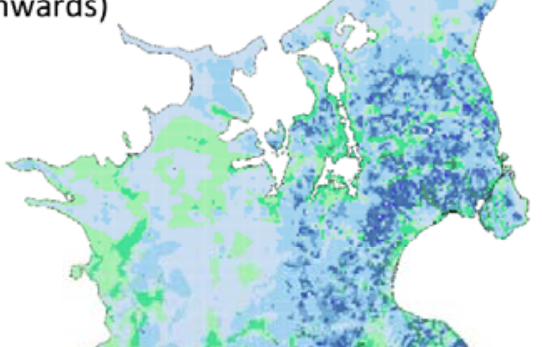

\section{Groundwater}

recharge

( $\mathrm{mm} /$ year)

\section{$=<-100$
$=-100-10$
$=-10-0$ \\ $=-10-0$}

0
$=0.10$

$\begin{aligned} & 0.10 \\ & =10 \\ = & 10.50 \\ = & 5\end{aligned}$

$=50 \cdot 100$
$=<100$

Figure 3: Groundwater recharge for actual abstraction (2003-2012) for three delineations: a) GWRinf is net

274 infiltration (positive down), b) GWRnet, aquifer is groundwater recharge to and discharge from limestone aquifers

275 (positive down) and c) GWRaquifer is groundwater recharge to limestone aquifers. The groundwater recharge was modeled with the DK-model. 


\section{$278 \quad 3.1$ Actual abstraction and drawdown}

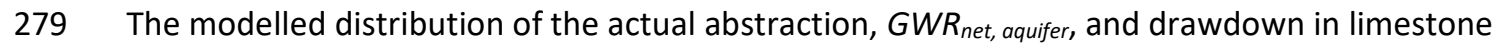

280 aquifers from 2003-2012 showed that water abstraction and $G W R_{\text {net, }}$ aquifer were greatest in the

281 eastern parts of Zealand (Figure $3 \mathrm{~b}$ and Figure 4). Actual abstraction resulted in local drawdowns in

282 limestone aquifers up to $24 \mathrm{~m}$ deep, while large areas had relatively small drawdowns (less than 2

$283 \mathrm{~m})$. Drawdowns less than $2 \mathrm{~m}$ even occurred in grid cells with an abstraction larger than 100,000

$284 \mathrm{~m}^{3} /$ year.

285 The correlation between the modelled and observed piezometric heads for 306 monitoring wells on

286 Zealand (SI. 3) showed a mean error (ME) of $-0.14 \mathrm{~m}$ and an RMSE of $2.7 \mathrm{~m}$. This was an excellent

287 result especially considering that the top score is given to an RMSE $<4$ in performance criteria when

288 considering the goodness of hydrological models (Henriksen et al., 2003). We also plotted the

289 difference in modelled and observed piezometric heads for the 28 well fields studied in Gejl et al.

290 (2019) (SI. 4), with the plot showing that generally the model is better at estimating relative changes

291 than absolute levels. With the overall good model fit, we found that it was well-suited to our

292 objective. 


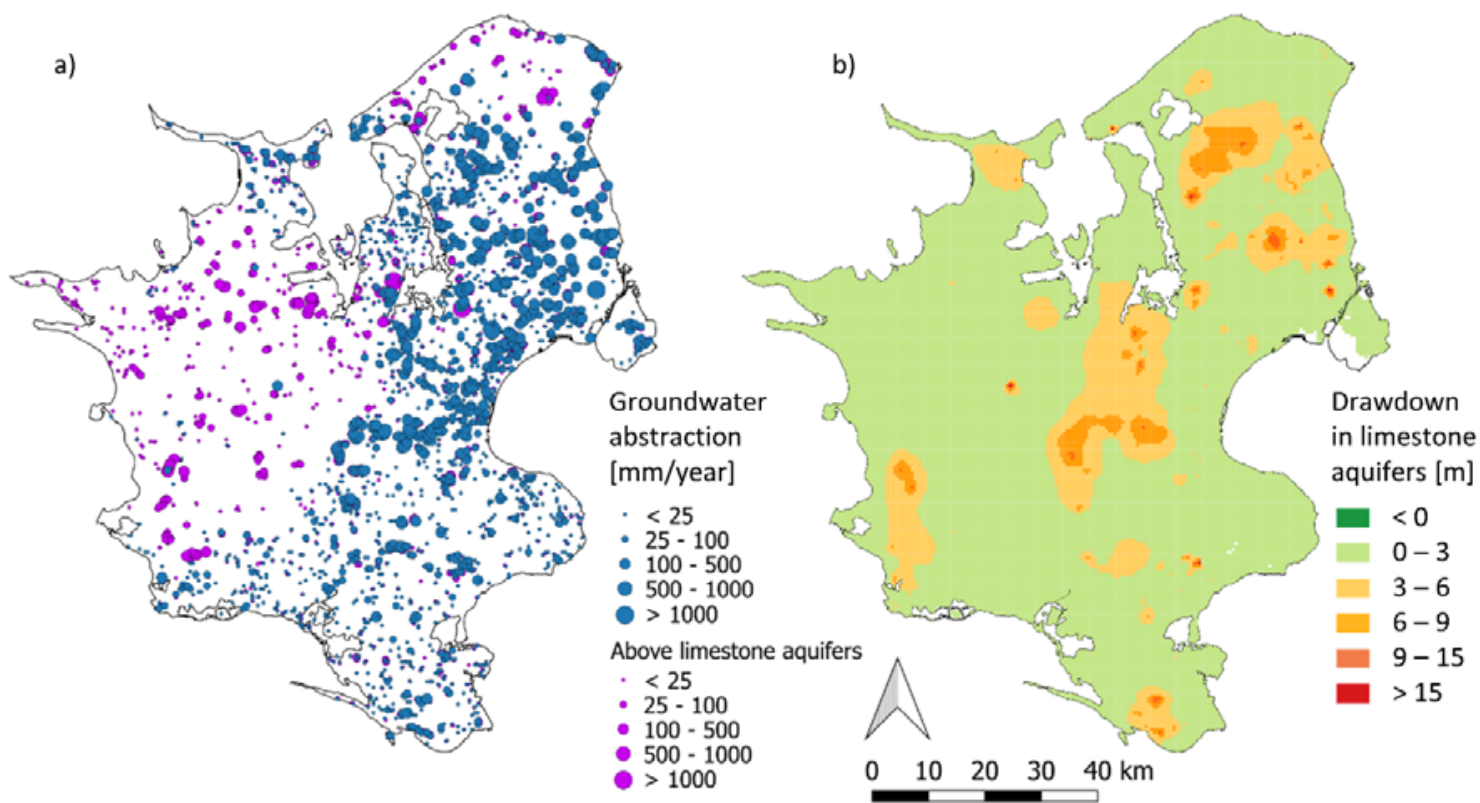

Figure 4: a) Actual average annual groundwater abstraction from 2003-2012 for private and public water supplies and b) modelled drawdown for actual abstraction on a grid size of $500 \times 500 \mathrm{~m}$.

297

\subsection{Drawdown}

For a conditioned drawdown of $3 \mathrm{~m}$, the modelled abstraction was distributed more equally

between the wells than for the actual abstraction (Figures 4 and SI. 5). Overall, the conditioned drawdown allowed for greater water abstraction than the actual abstraction from 2003-2012, but for some well fields, water abstraction would need to be reduced to obtain a maximum drawdown

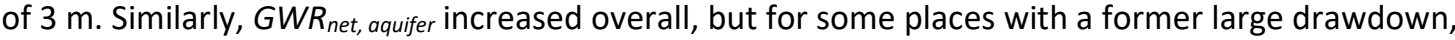
the $G W R_{\text {net, aquifer }}$ decreased.

\subsection{Components of impact assessment and the influence of drawdown}

The magnitude of the conditioned drawdown substantially influenced all components in AGWaRe, except $G W R_{\text {inf }}$ (Table 2). Regarding the system as a whole, a conditioned drawdown of $3 \mathrm{~m}$ allowed for an overall increase in abstraction to 261 million $\mathrm{m}^{3} / \mathrm{year}$, compared to the actual abstraction of 157 million $\mathrm{m}^{3} /$ year. Regarding the aquifer the conditioned drawdown dominated the quantification 
of $A M D_{\text {aquifer, }}$ which ranged from $27-208$ million $\mathrm{m}^{3} /$ year for conditioned drawdowns of 3 and $9 \mathrm{~m}$ respectively, meaning that the volumes of water available for other users greatly depend on the applied conditions. Similarly, the delineations of the groundwater system had a major influence on the components of AGWaRe (Table 2). As expected, considering the system as a whole, the components were larger than when considering the aquifer; for example, GW $R_{\text {inf }}$ were larger compared to both $G W R_{\text {net, aquifer }}$ and $G W R_{\text {aquifer. }}$ Furthermore, more water was needed for environmental purposes, $E G W R_{w q}$, when defiing groundwater recharge as $G W R_{\text {inf. }}$. For example, for a $3 \mathrm{~m}$ drawdown, and considering the entire groundwater system, 1344 million $\mathrm{m}^{3} /$ year would have to be reserved to ensure water quality in the aquifers. $E G W R_{w q}$ poses a large share of the groundwater recharge $(2.5-83 \%)$, depending on the boundaries and the sustainable drawdown. Considering $G W R_{\text {net, aquifer }}$ in the same regard, 26 million $\mathrm{m}^{3} /$ year would be needed. The conditioned drawdown is the same, but the boundaries - and thereby the quantification of $E G W R_{w q}$ - are different. $A M D_{\text {aquifer, }}$ ref for a $3 \mathrm{~m}$ drawdown is 27 million $\mathrm{m}^{3} / \mathrm{year}$, meaning that there is more water available within the sustainable limits.

Table 2: AGWaRe components for three system delineations of groundwater recharge (cf. Figure 2) for three conditioned drawdowns (3, 6 and $9 \mathrm{~m})$ on Zealand. WU is abstraction for the conditioned drawdown, and actual abstraction is the average abstraction from 2003 to 2012. Depending on the boundaries, AMD is found for the aquifer or for the groundwater system (GWS) where GWR refer to either GWR inf or GWRaquifer.

\begin{tabular}{|c|c|c|c|c|c|c|}
\hline $\begin{array}{l}\text { System under assessment } \\
\text { (delineation of GWR) }\end{array}$ & Drawdowns & $\begin{array}{c}\text { WU } \\
\left(\mathrm{Mm}^{3}\right)\end{array}$ & $\begin{array}{l}\text { GWR } \\
\left(\mathrm{Mm}^{3}\right)\end{array}$ & $\begin{array}{c}E G W R_{w q} \\
\left(\mathrm{Mm}^{3}\right)\end{array}$ & $A M D\left(\mathrm{Mm}^{3}\right)$ & DSC \\
\hline Groundwater system as a whole (GWS) & Actual abstraction (ref) & 157 & 1593 & & & \\
\hline \multirow[t]{3}{*}{$\left(G W R_{\text {inf }}\right)$} & $-3 m$ & 261 & 1605 & 1344 & 104 & 2.5 \\
\hline & $-6 m$ & 444 & 1630 & 1186 & 287 & 1.5 \\
\hline & $-9 m$ & 588 & 1647 & 1060 & 431 & 1.4 \\
\hline Aquifer & Actual abstraction (ref) & 112 & & & & \\
\hline \multirow[t]{2}{*}{ (GWR aquifer) } & $-3 m$ & 139 & 208 & 69 & 27 & 5.2 \\
\hline & $-6 m$ & 196 & 239 & 43 & 84 & 2.3 \\
\hline
\end{tabular}




\begin{tabular}{|c|c|c|c|c|c|c|}
\hline & $-9 m$ & 320 & 355 & 35 & 208 & 1.5 \\
\hline Aquifer & Actual abstraction (ref) & 112 & & & & \\
\hline \multirow[t]{3}{*}{ (GWR $\left.R_{\text {net, aquifer }}\right)$} & $-3 m$ & 139 & 165 & 26 & 27 & 5.2 \\
\hline & $-6 m$ & 196 & 213 & 16 & 84 & 2.3 \\
\hline & $-9 m$ & 320 & 328 & 8 & 208 & 1.5 \\
\hline
\end{tabular}

327

\subsection{Spatial resolution determines impact assessments}

$A M D_{\text {aquifer }}$ was evaluated for different scales (Figure 5), and for the largest of these, namely Zealand as a whole (not shown), groundwater was still available and could be used within the definition of sustainable groundwater abstraction. For example, if a drawdown of $3 \mathrm{~m}$ were allowed, there would be 27 million $\mathrm{m}^{3} / y e a r$ available in limestone aquifers on Zealand. There were two river basins with larger actual abstraction than what was available within the conditioned $3 \mathrm{~m}$ drawdown (river basins $4 \& 5$ in Figure 5.a), indicating that actual drawdowns pose a risk of changing water quality over time in these river basins. Forty-nine out of 205 river catchment areas had a negative $A M D_{\text {aquifer }}$ (Figure 5.b). The scale of ID15 showed a large variation in $A M D_{\text {aquifer }}$ around Zealand, where 146 out of 610 ID15 catchment areas had a negative $A M D_{\text {aquifer }}$ (Figure 5.c). Evaluating the smallest scale of $500 \mathrm{x}$ $500 \mathrm{~m}$, more than half of the grid cells with abstraction had a negative $A M D_{\text {qquifer }}$ (Figure 5.d), and $A M D_{\text {aquifer }}$ was generally larger than $A M D_{G W s}(\mathrm{SI} .5)$, which is expected, since absolute amounts of water available for use decrease downwards in the system. Scale is therefore a paramount choice in the assessment and comparison of water abstraction across regions. 

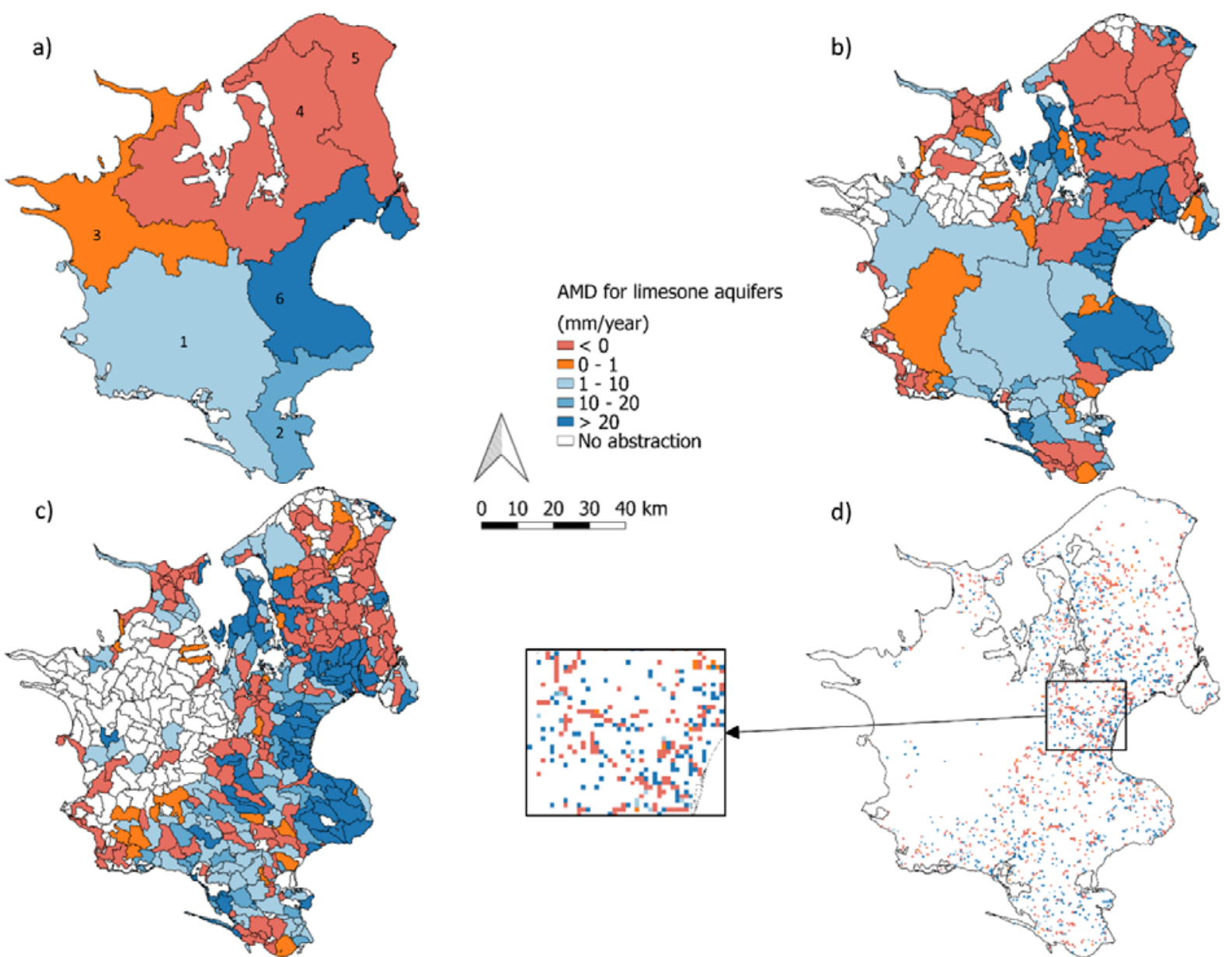

d)
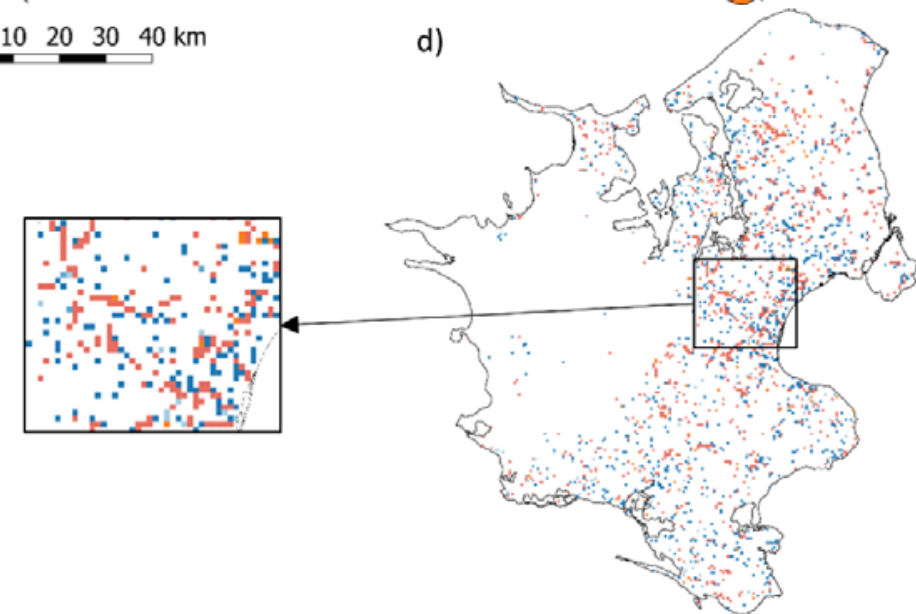

Figure 5: AMDaquifer for limestone aquifers on Zealand, for four scales: a) river basin, b) river catchments, c) ID15 and d) model grid.

\section{$344 \quad 3.5$ Spatial differences in the components of impact assessments and AGWaRe}

There are large differences in AGWaRe components between the river basins (Table 3). For example, river basin 3 had the smallest $G W R_{\text {aquifer, sus }}$ of 2.5 million $\mathrm{m}^{3} /$ year, and actual abstraction was 1.0 million $\mathrm{m}^{3} /$ year. For a drawdown of $3 \mathrm{~m}$, sustainable abstraction was 1.7 million $\mathrm{m}^{3} /$ year, indicating that there was 0.7 million $\mathrm{m}^{3} /$ year water available for use in the river basin's limestone aquifers $\left(A M D_{\text {aquifer }}\right)$. The difference between $G W R_{\text {aquifer, sus }}$ and $W_{\text {sus }}$ comprised the amount of water that should be left for sustaining water quality in the aquifer, $E G W R_{w q}$, which was 0.8 million $\mathrm{m}^{3} /$ year.

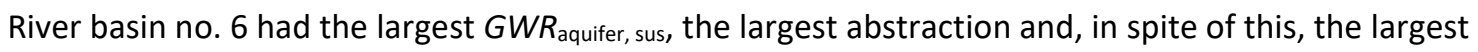
$A M D_{\text {aquifer }}$ of 25.5 million $\mathrm{m}^{3} /$ year, thus indicating that this river basin was affected the least. Since AGWaRe and $A M D_{\text {aquifer }}$ is inversely related and it is based on absolute values, the river basin obtained the lowest score with the largest amount of water remaining available for other uses. This 
355 is in contrast to relative assessments (e.g. WTA) that give the lowest score to the river basin with the 356 largest share of water remaining for other use, in this case river basin no. 2. Two river basins (no. 4

357 and 5) obtained the largest scores possible of 100, and river basin no. 6 obtained the small score of 3580.2 (Table 3). This indicates that groundwater stress on Zealand differs substantially, and the 359 aquifers in two river basins were at least 100 times more stressed than aquifers on Zealand in 360 general. Conversely, the aquifers in one river basin were five times less stressed than aquifers on 361 Zealand in general. Similar tables for drawdowns of 6 and $9 \mathrm{~m}$ can be found in SI. 6 . When comparing $362 A M D_{\text {aquifer }}$ for the different conditioned drawdowns, it is evident that $A M D_{\text {aquifer }}$ increased for all river 363 basins when a larger drawdown is allowed. $\mathrm{AMD}_{\text {ref }}$ changes according to the conditioned drawdown 364 definition, i.e. $\mathrm{AMD}_{\text {ref }}$ differs according to the constrains imposed on the model. Interestingly, DSC 365 and AGWaRe did not rank the river basins similarly (Table 3, SI. 6 and SI. 7), due to the difference in 366 the numerator. In addition, DSC was relative and AGWaRe represented absolute values. For River 367 Basin no. 1, the GWR was smaller than the abstraction for sustainable conditions, resulting in a negative $E G W R_{w q}$. This does not mean that the water needed to sustain water quality is negative; rather, it shows that the definition of $G W R_{\text {aquifer }}$ applied in this study (as the flow over a vertical 370 boundary) is simplified, since water will enter the aquifer horizontally from the sides in the model.

371 Horizontal flow between the river basins can result in negative $E G W R_{w q}$, albeit this is not the case for 372 the largest scale, i.e. Zealand (Table 2).

Table 3: AGWaRe parameters for limestone aquifers with a condition of a maximum $3 \mathrm{~m}$ drawdown for the river 374 basins on Zealand, given per year. Actual abstraction refers to average abstraction from 2003 - 2012. GWRaquifer, 375 sus is the groundwater recharge for a drawdown of $3 \mathrm{~m}$, and WU is the corresponding water abstraction. Numbers 376 have been rounded off.

\begin{tabular}{|c|c|c|c|c|c|c|c|}
\hline $\begin{array}{c}\text { River Basin } \\
\text { no. }\end{array}$ & $\begin{array}{c}\boldsymbol{G} W \boldsymbol{R}_{\text {aquifer, }} \\
\text { sus }\end{array}$ & $\begin{array}{c}W_{\text {actual }} \\
\left(\text { million } \mathrm{m}^{3} \text { ) }\right.\end{array}$ & $\begin{array}{c}W_{\text {sus-3m }} \\
\left(\text { million } \mathrm{m}^{3} \text { ) }\right.\end{array}$ & $\begin{array}{c}E G W R_{w q} \\
\left(\text { million } \mathrm{m}^{3}\right)\end{array}$ & $\begin{array}{c}A M D_{\text {aquifer }} \\
\left(\text { million } \mathrm{m}^{3} \text { ) }\right.\end{array}$ & $\begin{array}{c}\text { AGWaRe } \\
(-)\end{array}$ & $\begin{array}{c}D S C \\
(-)\end{array}$ \\
\hline & $\left(\right.$ million $\mathrm{m}^{3}$ ) & & & & & & \\
\hline 1 & 21.7 & 16.3 & 22.3 & -0.6 & 6.0 & 0.7 & 3.7 \\
\hline
\end{tabular}




\begin{tabular}{lccccccc}
\hline $\mathbf{2}$ & 14.5 & 2.7 & 8.3 & 6.2 & 5.6 & 0.8 & 1.5 \\
\hline $\mathbf{3}$ & 2.5 & 1.0 & 1.7 & 0.8 & 0.7 & 6.2 & 2.4 \\
\hline $\mathbf{4}$ & 44.2 & 40.6 & 36.4 & 7.8 & -4.2 & 100 & 100 \\
\hline $\mathbf{5}$ & 17.5 & 19.5 & 12.5 & 5.0 & -7.1 & 100 & 100 \\
\hline $\mathbf{6}$ & 64.3 & 32.0 & 57.6 & 6.7 & 25.5 & 0.2 & 2.3
\end{tabular}

377

378 Considering the ID15 catchment areas, $60 \%$ of the abstracted water on Zealand comes from water-

379

380

381

382

scarce zones with an $A M D_{\text {aquifer }}$ smaller than zero (Figure 6.a). Approximately $30 \%$ comes from aquifers in water-abundant ID15 catchment areas, with an AMD $>10 \mathrm{~mm} /$ year. Evaluating the abstraction distribution and the corresponding impact on a river catchment scale or river basin scale resulted in somewhat similar numbers. Comparing $A M D_{\text {aquifer }}$ for ID15 catchment areas to river catchment scale and river basin scale, the aquifers in ID15 catchment areas had greater water deficiency $\left(A M D_{\text {aquifer }}<0 \mathrm{~mm} /\right.$ year) than river catchment areas or basins (Figure 6.b). Similarly, a larger share of ID15 catchment areas had more water available for use. Thereby, evaluating $A M D_{\text {aquifer }}$ for ID15 catchment areas suggested a larger redistribution of water abstraction than evaluating for river basin areas. To obtain more sustainable groundwater abstraction, water managers could use this knowledge when revising abstraction distribution and for planning new well fields.

a)
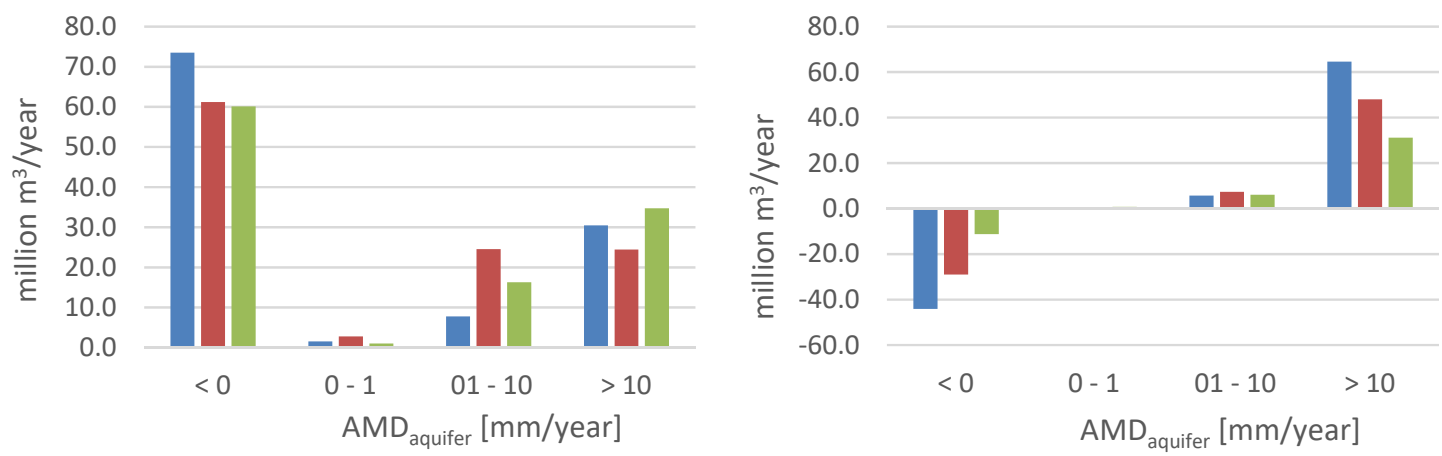

Figure 6: a) Distribution of abstraction within different AMD ranges for ID15 catchments, river catchment areas and river basins and b) the potential water abstraction that can be withdrawn before AMDaquifer reaches zero. 


\section{Discussion}

Our proposed method strives to assess groundwater sustainability, beyond the impacts on water balance, surface water systems and associated ecosystems, as covered in existing calculations for $E G W R_{\text {flow }}(G E U S, 2018)$. We attempt to evaluate potential impacts on aquifer water quality by evaluating the effects on drawdown rather than abstraction or percentages of GWR. It is a step towards obtaining the tools necessary to manage groundwater abstraction by considering groundwater quality and managing drawdown more systematically.

\subsection{The influence of drawdown}

Table 2 indicates that the conditioned drawdown greatly influences how much water can be withdrawn from groundwater, in that changing it from 3 to $9 \mathrm{~m}$ allows for doubling abstraction, thereby indicating that three times as much water is available for other uses, with an $A M D_{\text {aquifer }}$ of 104 and 431 million $\mathrm{m}^{3} /$ year, respectively. Consequently, it is important that the implementation of a conditioned drawdown is in combination with an in-depth understanding of the impacts related to the conditioned drawdown in the studied area, e.g. changes in gradient and reduced run-off to groundwater-dependent ecosystems. Discussions on an appropriate conditioned drawdown can be found in SI. 1 and Gejl et al. (2019).

\subsection{Different indicators, different aims}

Different indicators have different objectives. Whereas AWaRe, AGWaRe and AMD aim at comparing stress between different locations, DSC aims at indicating absolute stress at any given location. AWaRe and AGWaRe is developed for integration in LCA and therefore relates to current conditions and focuses on how they can be improved (Boulay et al., 2017; Gejl et al., 2018). All indicators evaluate the impact on the groundwater resource. In this study, we wanted to develop tools applicable in groundwater-based utilities, including for use in LCAs of their environmental impacts, and so in this regard we suggest $A G W a R e$ and $A M D_{\text {aquifer }}$ as being particularly useful. 
417 Current global freshwater use lies within a 'safe operating space' in terms of planetary boundaries,

418 i.e. there is a low risk of human-induced destabilisation of the earth's systems on a planetary scale

419 (Steffen et al., 2015). Planetary boundaries constitute an important step towards sustainable use for

420 some resources; however, for water, sustainable use differs around the world, and currently, there

421 are many places with human-induced water scarcity (Haddeland et al., 2014; World Water

422 Assessment Programme, 2009). DSC was developed to incorporate local, sustainable boundaries in

423 the indicator.

424 The model iterates abstractions from confined aquifers, which for Zealand constitutes $93 \%$ of water

425 abstraction, and the iteration does not consider water abstraction in upper aquifers. For our case, it

426 is therefore reasonable to assume that the majority of actual impacts related to groundwater

427 abstraction were included in our assessment. However, if a similar evaluation were conducted in

428 areas where irrigation or other water abstractions from the top aquifers constitute a larger share of

429 water abstraction, an analysis of the relevance of including all groundwater abstractions (including

430 irrigation and industry) should be conducted.

$431 \quad 4.3$ Appropriate scale

432 The choice of scale greatly affected the results (Figure 5). The internationally recognised indicator

433 AWaRe is an administrative demarcation consisting of a large grid too coarse for assessing relevant

434 impacts of water utilities on Zealand (Figure 7). It indicates that the largest effects are seen in the

435 outer parts of Zealand, and the area we would expect to be most stressed (close to Copenhagen) has

436 the smallest impact on Zealand (Figure 7). Hence, it is difficult to use AWaRe in local assessments at

437 the sub-national scale in the case of Denmark. 


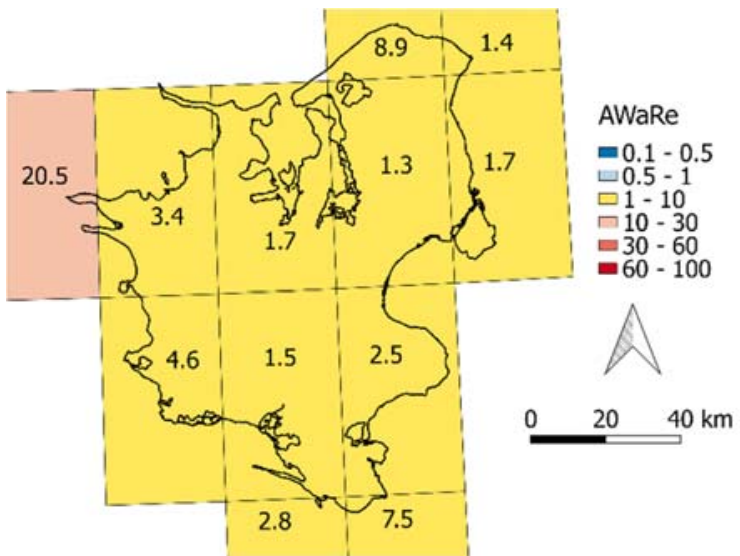

Figure 7: AWaRe characterisation factors for non-agricultural water use. Based on data from WULCA (2014)

The scales applied in this paper have their own individual advantages and disadvantages (Table 1).

Between the five applied scales, the Zealand scale hides the groundwater stress that was found locally, and it cannot show which areas are more stressed than others. The river basins scale is coarser than AWaRe, but it does allow for the better representation than AWaRe of impacts in coastal areas (Figures 5 and 7); however, river catchments differ greatly in size, and so it is deemed too non-uniform for this assessment. ID15 catchment areas and model grid cells are small scales and can identify hotspots better than river basins or the AWaRe grid. Evaluating water balances within a grid scale measuring $500 \times 500 \mathrm{~m}$ is a very detailed undertaking, and sometimes it is actually too detailed to represent realistic impacts. All of the studied scales have the disadvantage that they are based on hydrological catchments, rather than on groundwater catchments. For assessing local groundwater impacts, we suggest using a relatively small scale; for instance, in our case, the ID15 scale shows local differences and therefore can assist in the local planning, for example, of where to place a new well field, or redistributing abstraction by increasing it at one well field and reducing it at another. Using river catchment areas or ID15 catchment areas will help in indicating stress on a scale relevant for water supplies, whenever global assessments (e.g. Alcamo et al., 2003; Boulay et al., 2017; Gleeson et al., 2012) hide groundwater stress in terms of planning water withdrawal. Furthermore, ID15 and river catchment areas can be relevant in relation to gap analysis and river basin management plans (European Union, 2000). Eventually, a more homogenous subset of river 
catchments more equal in size, consisting of clustered ID15 catchments in alignment with topographic and groundwater divides, could provide a stronger foundation for quantitative status assessments in future river basin management plans.

Future assessments should also consider $A M D_{\text {aquifer }}$ calculated for a 3D scale such as groundwater bodies. One disadvantage, though, is that groundwater bodies may overlap vertically, so it would be difficult to compare with the other scales applied. We recommend further work on delineating groundwater resources, to obtain relevant demarcations of groundwater resources and to ensure trustworthy assessments of impacts on the groundwater resource.

\subsection{Defining groundwater recharge}

The boundaries of groundwater recharge had a large influence on the results. Securing reliable impact assessments requires consistent and accepted delineation of groundwater processes, and for comparing independent evaluations, it is crucial to have similar delineations of the components in the impact assessment. Defining groundwater recharge as $G W R_{\text {inf }}$ (c.f. Figure 2) gave an indication of water availability in the groundwater system but little information on availability in the aquifer. In reality, a large fraction will be drained or discharged into streams on Zealand. On the other hand, defining groundwater recharge as $G W R_{\text {net, aquifer }}$ provided concise information about water availability in the aquifer, albeit with little information of impacts on streams and surface water. Furthermore, this boundary resulted in large differences in $G W R_{\text {net, aquifer }}$ across Zealand, due, amongst other influencers, to variations in the elevation of the limestone aquifers (Figure 1). To ensure that the groundwater impact is reflecting groundwater stress, we used $G W R_{\text {net, aquifer }}$ in this study.

\subsection{Vulnerability, contamination and other water quality issues}

This study focused on including water quality affected by abstraction (Gejl et al., 2019). However, there could be other reasons for poor groundwater quality, such as saltwater intrusion (Ataie-

Ashtiani et al., 2012), geogenic releases of nickel and arsenic (Miotliński et al., 2012; Polizzotto et al., 2008; Postma et al., 2012), the formation of chloroform compounds in forested areas (Laturnus et 
483 al., 2000), impacts from the agricultural use of pesticides and fertilisers (Aisopou et al., 2014) and

484 leaching from contaminated sites, for example spills at industrial production facilities, gasoline

stations or old landfills (Locatelli et al., 2019). These water quality issues have not been considered

in this study, but they will certainly influence where and how much water can be abstracted.

Including these potential problems, we would expect that some vulnerable areas would be excluded

from the analysis, due to poor water quality, and hence overall water availability would decrease.

This is a relevant topic for further studies. To ensure holistic assessments, all local water quality

issues or other relevant local aspects should be included, in order to obtain a complete picture.

\subsection{Centralised vs. distributed groundwater abstraction}

This study was based on the location of actual groundwater abstraction. If the wells were located differently, abstraction volumes corresponding to a conditioned drawdown would change, since the piezometric heads in the wells are interconnected. The approach applied in this study suggests that evenly distributed groundwater abstraction would be more sustainable concerning drawdown, because the lowering of the piezometric heads would be levelled out. This could indicate that centralised waterworks have significant impacts; however, the main point is to ensure a good distribution of abstraction between well fields. The actual physical placement of the waterworks is in reality a prioritisation between access to reliable water resources with stable water quality and costs for distribution pipes, pumping, etc. The method could encourage planners to distribute abstraction over larger areas while highlighting areas with excessive abstractions.

In theory, if we placed wells evenly distributed (in all grid cells in the model) the allowed abstraction would increase drastically within the conditioned drawdown. If we fully understand the impacts of drawdown, this would not be a problem, since the drawdown would be set to ensure stable groundwater quality; however, this is not actually feasible, due to groundwater infrastructure costs. 


\section{Conclusions}

Our study developed and demonstrated a novel method for screening for sustainable groundwater abstraction, by managing groundwater abstraction according to a certain drawdown in confined aquifers' piezometric heads. This method has numerous application possibilities; for instance, it can be used to benchmark water utilities, it can be part of LCAs that focus on local water stress and it can be utilised by water utilities when planning for water security (European Union, 2000). The method was tested on Zealand, and it provides a viable contribution to the quantification of sustainable groundwater abstraction. Future developments should focus on the application of the method for different types of hydrogeological settings and test its use in other parts of Denmark and internationally.

We introduce a selection of new indicators for the groundwater impact assessment, e.g. 1) DSC that is relevant for evaluating how far groundwater abstraction is from sustainable conditions, 2) a spatially differentiated $E G W R_{w q}$ based on conditioned drawdown, which upon implementation in groundwater management will assist to ensure stable groundwater quality, and 3) AGWaRe and $A M D_{\text {aquifer }}$ for actual groundwater abstraction based on the novel component $E G W R_{w q}$ for use in environmental impact assessments such as LCAs.

We suggest that a spatial-scale definition similar to the Danish ID15 catchment area scale $(0.07-105$ $\mathrm{km}^{2}$, median $11 \mathrm{~km}^{2}$ ) is currently the most practical and relevant scale for evaluating groundwater stress induced by water utilities.

Through the method applied for Zealand, it was found that for actual abstraction (2003-2012) there was an additional 27 million $\mathrm{m}^{3} /$ year of water available, if a drawdown of 3 metres is allowed. $E G W R_{w q}$ was quantified and amounted up to $83 \%$ of GWR and hence it is important to account for possible changes to groundwater quality when managing groundwater abstraction. However, actual abstraction should be redistributed in order to meet the conditioned drawdown in all the aquifers. To achieve a positive $A M D_{\text {aquifer }}$ in all ID15 catchment areas, 41 million $\mathrm{m}^{3} /$ year should be moved to 
531 areas with more water availability. The methodology is a step towards obtaining tools to manage

532 groundwater abstraction, by considering groundwater quality, and to manage drawdown more

533 systematically, and it can be part of future holistic decision-making in water management scenarios,

534 in order to distribute water abstraction accordingly and thus minimise water stress.

$535 \quad 5.1$ Acknowledgements

536 This study was conducted at the Department of Environmental Engineering at Technical University of

537 Denmark in collaboration with Hovedstadsområdets Forsyningsselskab, HOFOR, VandCenter Syd and

538 Aarhus Vand. The work is part of an industrial PhD programme, funded by the utility partners and

539 Innovation Fund Denmark.

540 


\section{References}

Aisopou, A., Binning, P.J., Albrechtsen, H.J., Bjerg, P.L., 2014. Modeling the Factors Impacting Pesticide Concentrations in Groundwater Wells. Groundwater 53, 722-736. https://doi.org/10.1111/gwat.12264

Alcamo, J., Döll, P., Henrichs, T., Kaspar, F., Lehner, B., Rösch, T., Siebert, S., 2003. Development and testing of the WaterGAP 2 global model of water use and availability. Hydrol. Sci. J. 48, 317338. https://doi.org/10.1623/hysj.48.3.317.45290

Alcamo, J., Henrichs, T., 2002. Critical regions: A model-based estimation of world water resources sensitive to global changes. Aquat. Sci. 64, 352-362. https://doi.org/10.1007/PL00012591

Ataie-Ashtiani, B., Simmons, C.T., Barry, D.A., Vandenbohede, A., Werner, A.D., Lu, C., Post, V.E.A., Bakker, M., 2012. Seawater intrusion processes, investigation and management: Recent advances and future challenges. Adv. Water Resour. 51, 3-26. https://doi.org/10.1016/j.advwatres.2012.03.004

Boulay, A.M., Bare, J., Benini, L., Berger, M., Lathuillière, M.J., Manzardo, A., Margni, M., Motoshita, M., Núñez, M., Pastor, A.V., Ridoutt, B., Oki, T., Worbe, S., Pfister, S., 2017. The WULCA consensus characterization model for water scarcity footprints: assessing impacts of water consumption based on available water remaining (AWARE). Int. J. Life Cycle Assess. 1-11. https://doi.org/10.1007/s11367-017-1333-8

Bredehoeft, J.D., 2002. The water budget myth revisited: Why hydrogeologists model. Groundwater 40, 340-345.

Doeg, T., Muller, K., Nicol, J., Vanlaarhoven, J., 2012. Environmental Water Requirements of Groundwater Dependent Ecosystems in the Musgrave and Southern Basins Prescribed Wells Areas on the Eyre Peninsula, DFW Technical Report 2012/16. Adelaide. 
European Union, 2006. The groundwater directive (Directive 2006/118/EC of the European Parliament and of the council of 12 December 2006 on the protection of groundwater against pollution and deterioration). Off. J. Eur. Union 19, 19-31. https://doi.org/http://eurlex.europa.eu/legal-content/EN/TXT/?uri=CELEX:32006L0118

European Union, 2000. The Water Framework Directive (Directive 2000/60/EC of the European Parliament and of the Council of 23 October 2000 establishing a framework for Community action in the field of water policy). Off. J. Eur. Parliam. L327, 1-82. https://doi.org/10.1039/ap9842100196

Gejl, R.N., Bjerg, P.L., Henriksen, H.J., Hauschild, M.Z., Rasmussen, J., Rygaard, M., 2018. Integrating groundwater stress in life-cycle assessments - An evaluation of water abstraction. J. Environ. Manage. 222. https://doi.org/10.1016/j.jenvman.2018.05.058

Gejl, R.N., Rygaard, M., Henriksen, H.J., Rasmussen, J., Bjerg, P.L., 2019. Understanding the impacts of groundwater abstraction through long-term trends in water quality. Water Res. 156, 241251.

GEUS, 2018. VandWeb. Timeseries for water abstraction, flows and connected ecological state for different abstraction scenarios calculated with the DK-model for 30.000 stream stations [WWW Document]. URL http://dk.vandmodel.dk/vandweb/ (accessed 3.14.19).

GEUS, 2009. DK-modellen. Hydrological model of Denmark. Description available at: http://vandmodel.dk/vm/om_os/index.html [WWW Document].

Gleeson, T., Wada, Y., 2013. Assessing regional groundwater stress for nations using multiple data sources with the groundwater footprint. Environ. Res. Lett. 8, 044010. https://doi.org/10.1088/1748-9326/8/4/044010 
607

revealed by groundwater footprint. Nature 488, 197-200.

https://doi.org/10.1038/nature11295

Graeber, D., Wiberg-Larsen, P., Bøgestrand, J., Baattrup-Pedersen, A., 2015. Vurdering af effekten af vandindvinding på vandløbs $\varnothing$ kologiske tilstand. Aarhus.

Haddeland, I., Heinke, J., Biemans, H., Eisner, S., Flörke, M., Hanasaki, N., Konzmann, M., Ludwig, F., Masaki, Y., Schewe, J., Stacke, T., Tessler, Z.D., Wada, Y., Wisser, D., 2014. Global water resources affected by human interventions and climate change. Proc. Natl. Acad. Sci. 111, 3251-3256. https://doi.org/10.1073/pnas.1222475110

Henriksen, H.J., Refsgaard, J.C., 2013. Sustainable groundwater abstraction - a review report. Danmarks og Grønlands Geologiske Undersøgelse Rapport. 2013/30. GEUS.

Henriksen, H.J., Sonnenborg, A., 2003. Ferskvandets kredsløb. Danmarks og Grønlands Geologiske Tema Rapport. GEUS.

Henriksen, H.J., Troldborg, L., Højberg, A.L., Refsgaard, J.C., 2008. Assessment of exploitable groundwater resources of Denmark by use of ensemble resource indicators and a numerical groundwater-surface water model. J. Hydrol. 348, 224-240. https://doi.org/10.1016/j.jhydrol.2007.09.056

Henriksen, H.J., Troldborg, L., Nyegaard, P., Sonnenborg, T.O., Refsgaard, J.C., Madsen, B., 2003. Methodology for construction, calibration and validation of a national hydrological model for Denmark. J. Hydrol. 280, 52-71. https://doi.org/10.1016/S0022-1694(03)00186-0

Hoekstra, A.Y., 2016. A critique on the water-scarcity weighted water footprint in LCA. Ecol. Indic. 66, 564-573.

Hoekstra, A.Y., Mekonnen, M.M., Chapagain, A.K., Mathews, R.E., Richter, B.D., 2012. Global monthly water scarcity: Blue water footprints versus blue water availability. PLoS One 7. 
Højberg, A.L., Stisen, S., Olsen, M., Troldborg, L., Uglebjerg, T.B., Jørgensen, L.F., 2015. DKmodel2014 Model opdatering og kalibrering.

Højberg, A.L., Troldborg, L., Stisen, S., Christensen, B.B.S., Henriksen, H.J., 2013. Stakeholder driven

Hybel, a.-M., Godskesen, B., Rygaard, M., 2015. Selection of spatial scale for assessing impacts of groundwater-based water supply on freshwater resources. J. Environ. Manage. 160, 90-97. https://doi.org/10.1016/j.jenvman.2015.06.016

International River Foundation, 2007. The Brisbane Declaration (2007).

Jones, J., Anthony, A. (Eds.), 2011. Sustaining Groundwater Resources - A Critical Element in the Global Water Crisis.

Klint, K.E.S., Nilsson, B., Troldborg, L., Jakobsen, P.R., 2013. A poly morphological landform approach for hydrogeological applications in heterogeneous glacial sediments. Hydrogeol. J. 21, 12471264. https://doi.org/10.1007/s10040-013-1011-2

Larsen, F., Postma, D., 1997. Nickel mobilization in a groundwater well field: Release by pyrite oxidation and desorption from manganese oxides. Environ. Sci. Technol. 31, 2589-2595. https://doi.org/10.1021/es9610794

Laturnus, F., Lauritsen, F.R., Grøn, C., 2000. Chloroform in a pristine aquifer system: Toward an evidence of biogenic origin. Water Resour. Res. 36, 2999-3009. https://doi.org/10.1029/2000WR900194

Locatelli, L., Binning, P.J., Sanchez-vila, X., Lemming, G., Rosenberg, L., Bjerg, P.L., 2019. A simple contaminant fate and transport modelling tool for management and risk assessment of 

groundwater pollution from contaminated sites. J. Contam. Hydrol. 221, 35-49.

Miotliński, K., Postma, D., Kowalczyk, A., 2012. Variable infiltration and river flooding resulting in changing groundwater quality - A case study from Central Europe. J. Hydrol. 414-415, 211-219. https://doi.org/10.1016/j.jhydrol.2011.10.034

Nunez, M., Bouchard, C., Bulle, C., Boulay, A.-M., Margni, M., 2016. Critical analysis of life cycle impact assessment methods addressing consequences of freshwater use on ecosystems. Int. J. Life Cycle Assess. submitted. https://doi.org/10.1007/s11367-016-1127-4

Pfister, S., Boulay, A.-M., Berger, M., Hadjikakou, M., Motoshita, M., Hess, T., Ridoutt, B., Weinzettel, J., Scherer, L., Döll, P., Manzardo, A., Núñez, M., Verones, F., Humbert, S., Buxmann, K., Harding, K., Benini, L., Oki, T., Finkbeiner, M., Henderson, A., 2017. Understanding the LCA and ISO water footprint: A response to Hoekstra (2016) “A critique on the water-scarcity weighted water footprint in LCA." Ecol. Indic. 72, 352-359. https://doi.org/10.1016/j.ecolind.2016.07.051

Pfister, S., Koehler, A., Hellweg, S., 2009. Assessing the Environental Impact of Freshwater Consumption in Life Cycle Assessment. Environ. Sci. Technol. 43, 4098-4104.

Polizzotto, M.L., Kocar, B.D., Benner, S.G., Sampson, M., Fendorf, S., 2008. Near-surface wetland sediments as a source of arsenic release to ground water in Asia. Nature 454, 505-508. https://doi.org/10.1038/nature07093

Postma, D., Larsen, F., Thai, N.T., Trang, P.T.K., Jakobsen, R., Nhan, P.Q., Long, T.V., Viet, P.H., Murray, A.S., 2012. Groundwater arsenic concentrations in Vietnam controlled by sediment age. Nat. Geosci. 5, 656-661. https://doi.org/10.1038/ngeo1540

Postma, D., Thi, P., Trang, K., Ugilt, H., Hoan, H. Van, Mai, V., Thi, N., Larsen, F., Hung, P., 2016. A model for the evolution in water chemistry of an arsenic contaminated aquifer over the last 

6000 years, Red River floodplain , Vietnam. Geochim. Cosmochim. Acta 195, 277-292. https://doi.org/10.1016/j.gca.2016.09.014

Smakhtin, V., Revenga, C., Döll, P., 2004. A Pilot Global Assessment of Environmental Water Requirements and Scarcity. Water Int. 29, 307-317. https://doi.org/10.1080/02508060408691785

Steffen, W., Richardson, K., Rockström, J., Cornell, S., Fetzer, I., Bennett, E., Biggs, R., Carpenter, S., 2015. Planetary boundaries: Guiding human development on a changing planet. Science 348, 1217. https://doi.org/10.1126/science.aaa9629

SVANA, 2016. Vandområdeplan 2015-2021 for Vandområdedistrikt Sjælland Juni 2016. Ministry of Environment and Food of Denmark.

Troldborg, L., Sørensen, B.L., Kristensen, M., Mielby, S., 2014. Afgrænsning af grundvandsforekomster - Tredje revision af grundvandsforekomster i Danmark. Danmarks og Grønlands Geologiske Undersøgelse Rapport 2014/58.

Völker, J., Borchardt, D., 2019. Drinking Water Quality at Risk: A European Perspective, in: Schröter M., Bonn A., Klotz S., Seppelt R., B.C. (Ed.), Atlas of Ecosystem Services. Springer, Cham, pp. 05. https://doi.org/10.1007/978-3-319-96229-0

World Water Assessment Programme, 2009. The United Nations World Water Development Report 3: Water in a Changing World, World Water. Paris: UNESCO, and London: Earthscan. https://doi.org/10.3390/w3020618

WULCA, 2014. AWaRe Characterization factors [WWW Document]. URL http://www.wulcawaterlca.org/aware.html (accessed 3.12.19).

WWAP, 2016. The United Nations World Water Development Report 2016: Water and Jobs. Paris, UNESCO. 
679 Zektser, I.S., Everett, L.G., 2004. Groundwater resources of the world and their use, IhP Series on 680 groundwater. No. 6. UNESCO, Paris.

681

682 


\section{Supplementary information}

\section{SI. 1: Defining sustainable groundwater abstraction}

From the study of correlations between water quality parameters and drawdown (Gejl et al., 2019), we can propose maximum allowed drawdown. The study showed that for the investigated well fields, changes in sulphate concentrations were connected to changes in water levels. There are some challenges involved in translating results from data into model characteristics, such as what constitutes pristine conditions in the real world, and how does a water level in a well translate into an average water level for a grid cell in the model? If we assume that the water level in the observation well (with a given distance away from the well field) represents the average water level for the grid cell with the abstraction well, and if we then also assume that the first measure of the water level represents pristine conditions, we can suggest, from a chosen acceptable change in sulphate concentration, a maximum lowering of the head. There are several ways to define an acceptable change in sulphate levels: 1) no change; assuming that an acceptable change in sulphate concentration is $50 \mathrm{mg} / \mathrm{L}$, based on a correlation (in Figure 5 in Gejl et al., 2019) that indicates a maximum $3 \mathrm{~m}$ lowering of the head. 2) If we allow a change in sulphate concentration to $75 \mathrm{mg} / \mathrm{L}$, we can change the piezometric head to approximately $6 \mathrm{~m}$. 3) If we allow for a change in sulphate concentration of $100 \mathrm{mg} / \mathrm{L}$, we can change the piezometric head at approximately $8 \mathrm{~m}$.

The well fields respond differently to abstraction, and therefore deciding on a common maximum drawdown suggests overly restrictive drawdowns for some well fields (where abstraction does not result in changing water quality) and excessively unrestricted drawdowns (in cases of well fields where water quality responds significantly to abstraction). For example, if a maximum drawdown is set to $6 \mathrm{~m}$, four well fields will increase by more than $75 \mathrm{mg} / \mathrm{L}$. One well field has a higher drawdown, without increasing the sulphate concentration to $75 \mathrm{mg} / \mathrm{L}$. Besides the geological and hydrogeological differences between well fields, we also expect that there will be different 

increases, i.e. the sixth metre has a greater impact than the first metre. 
711 

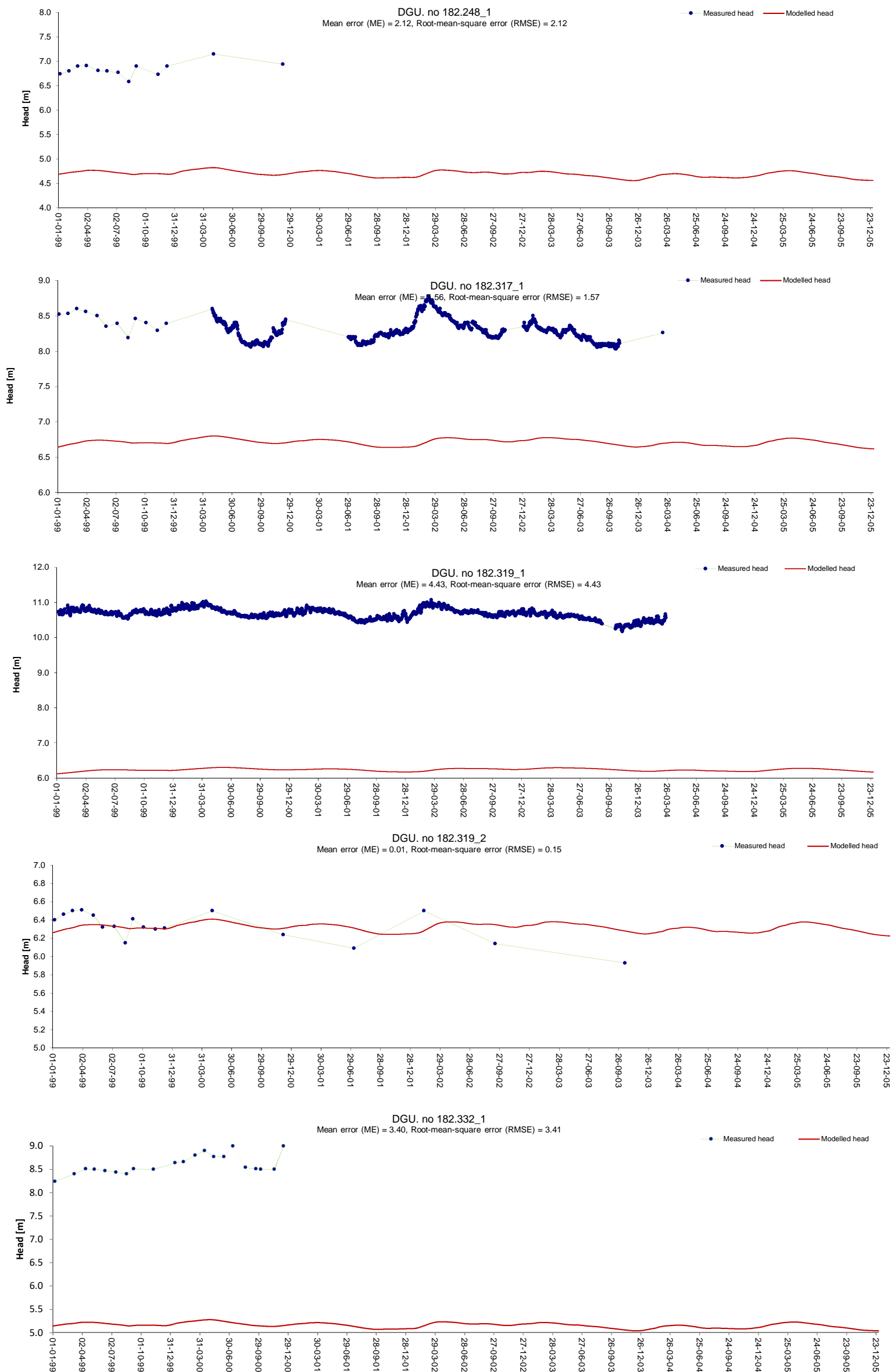

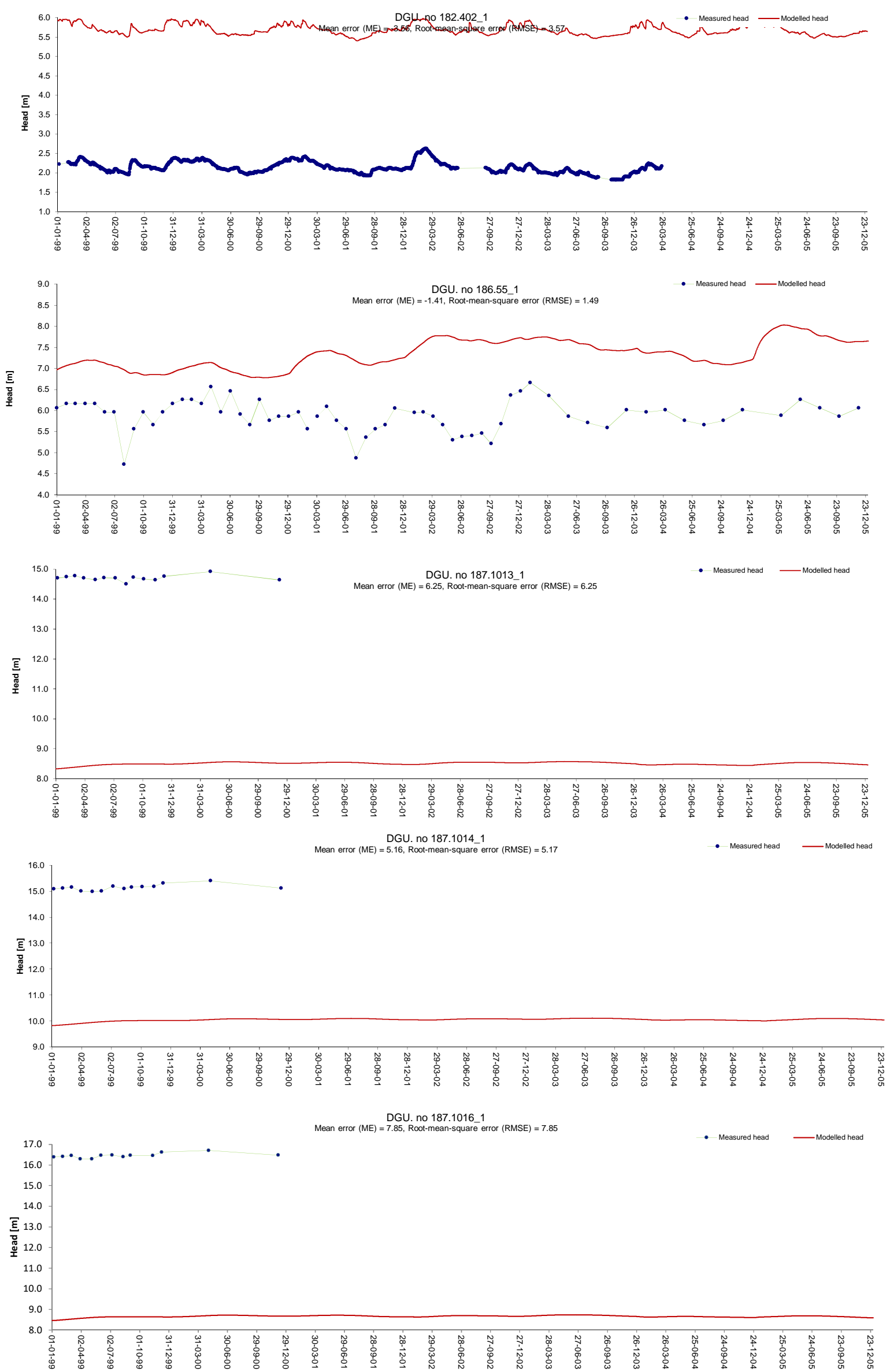

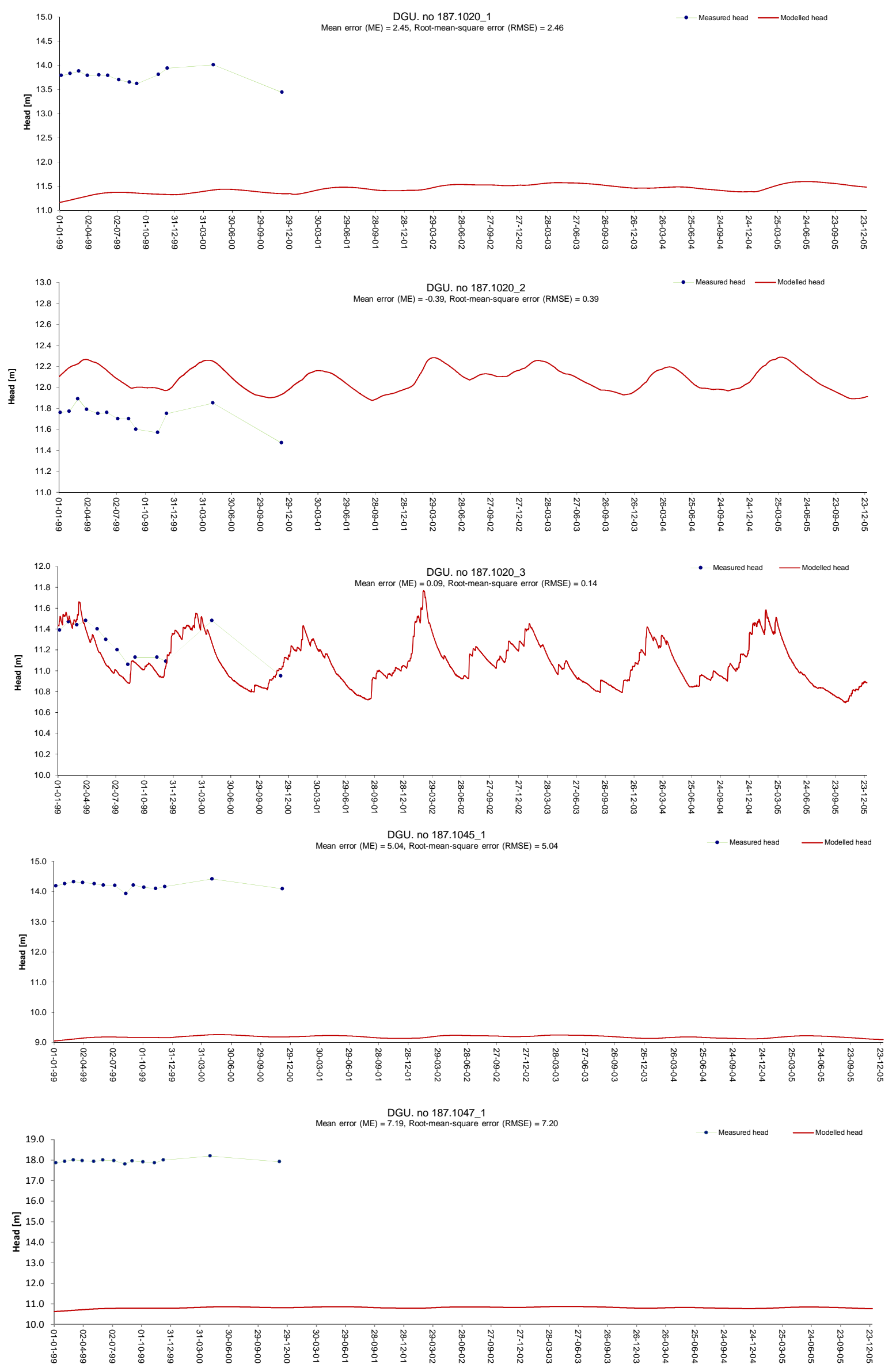

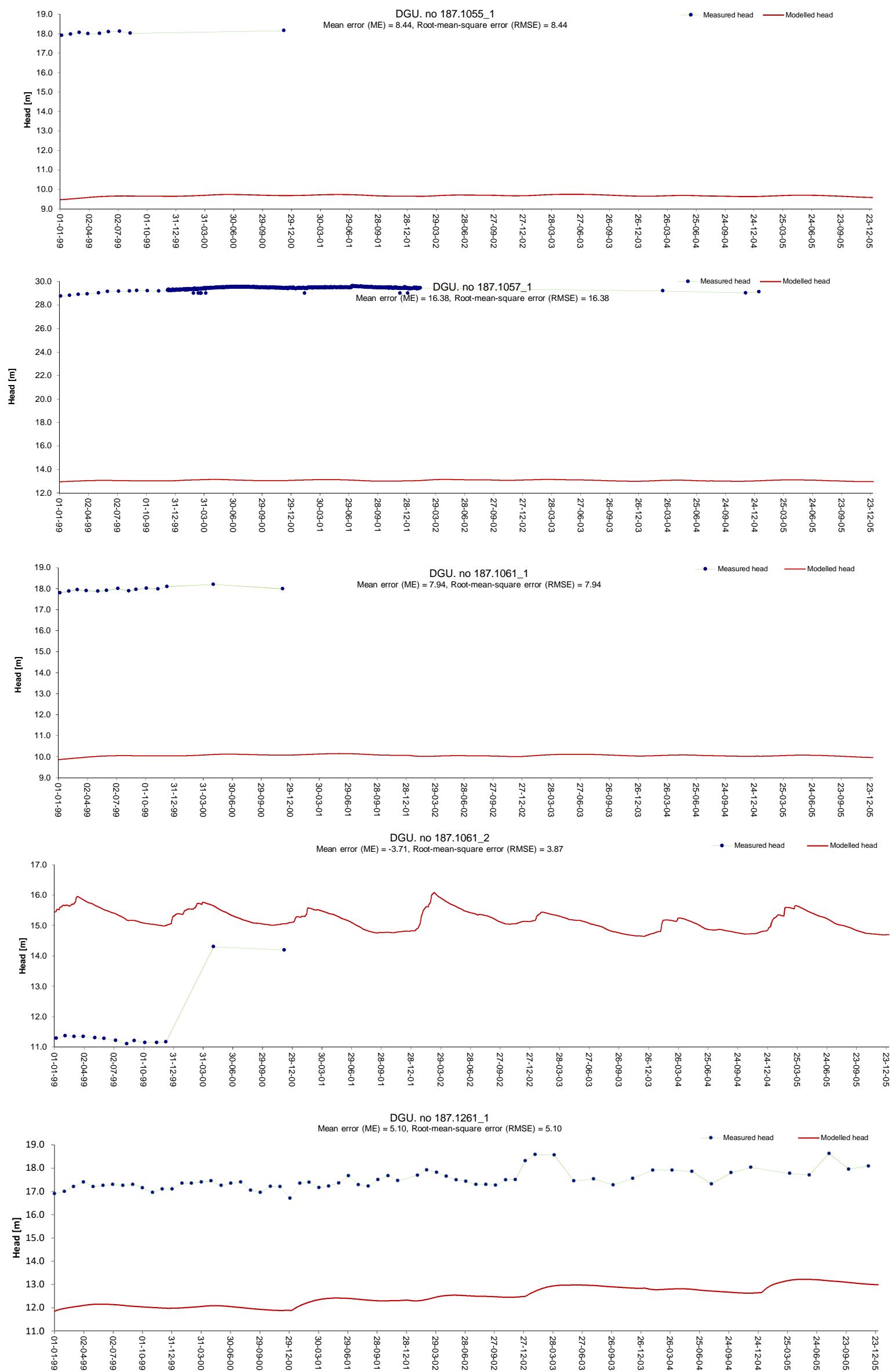

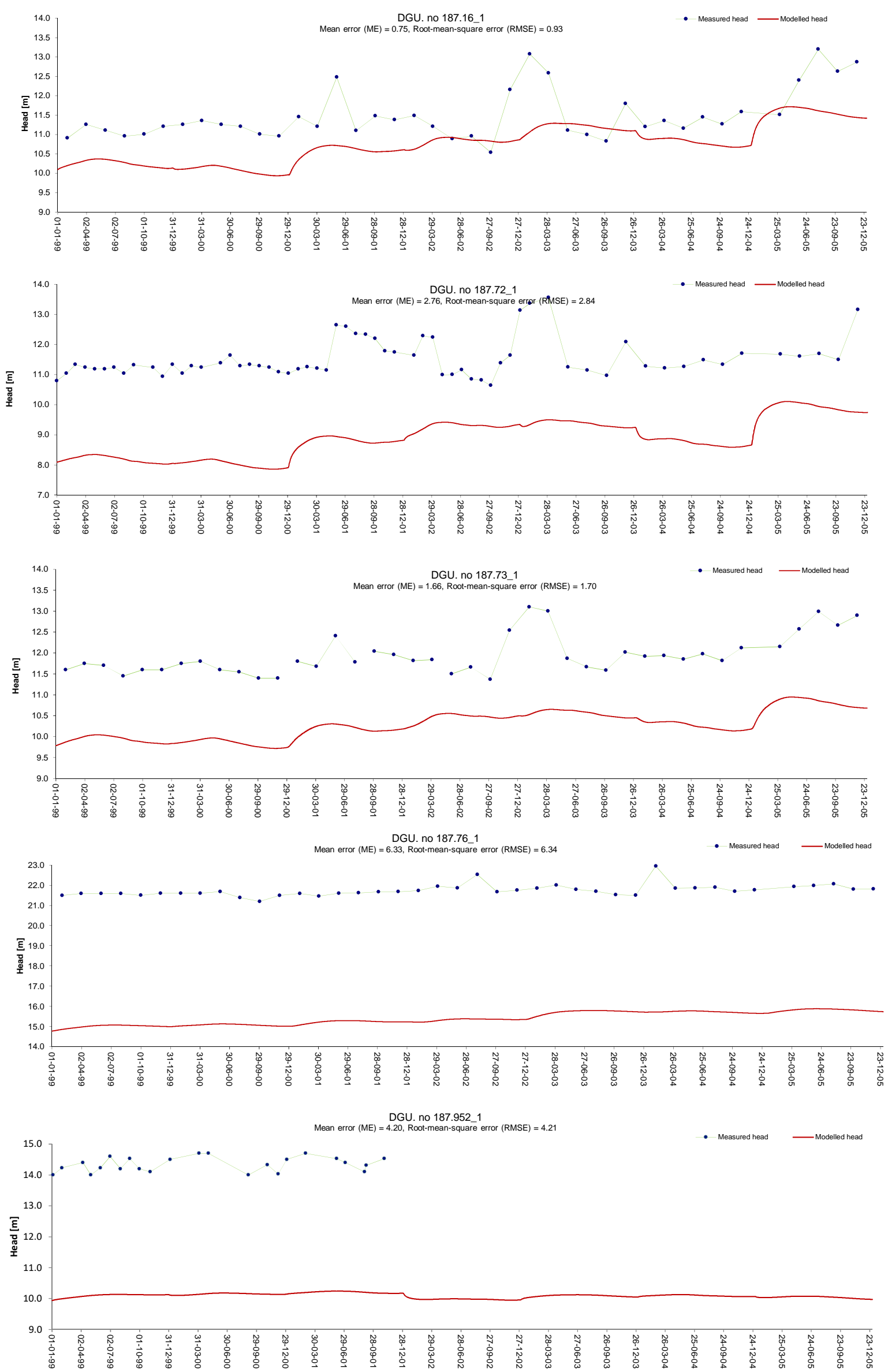

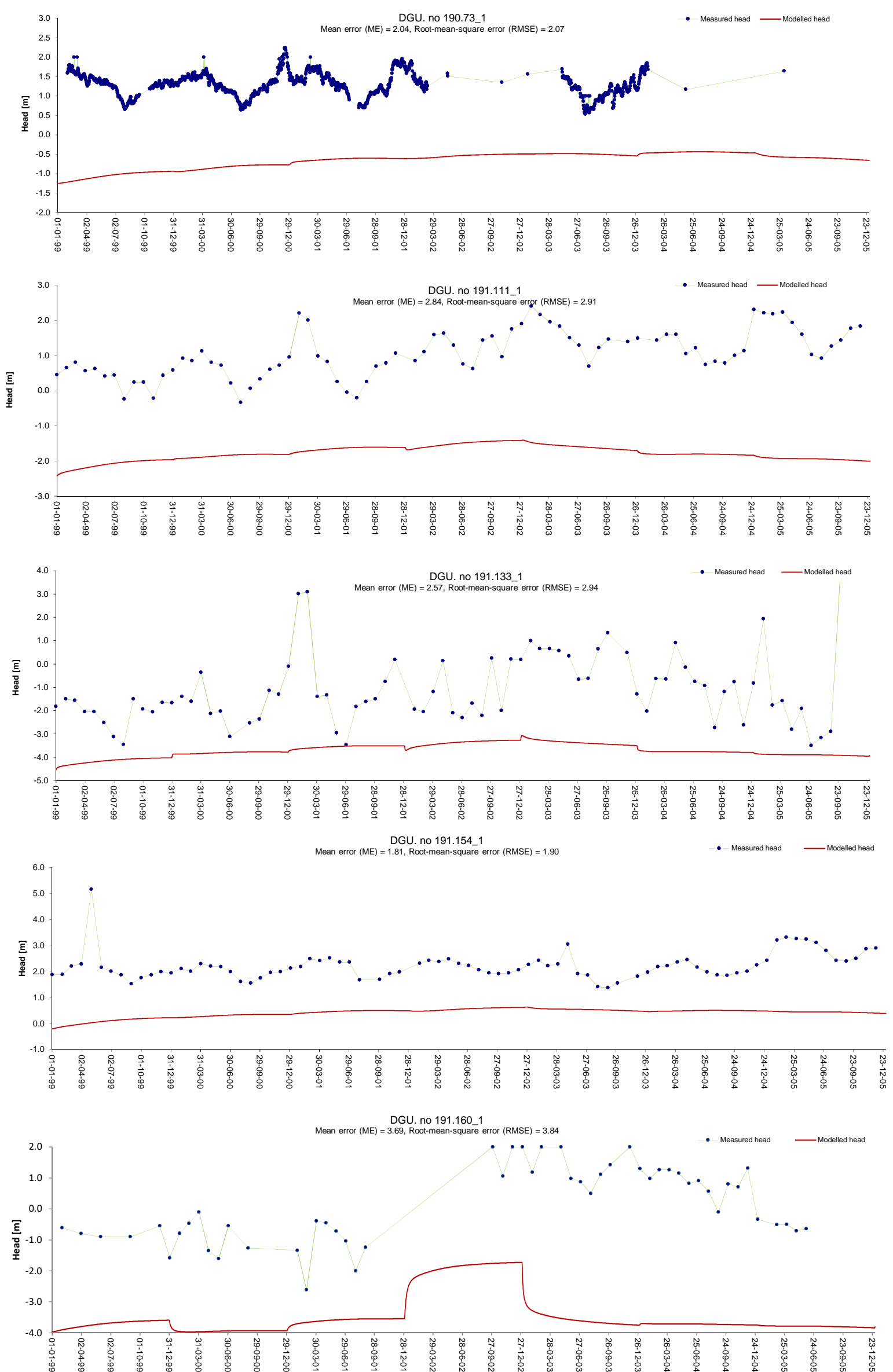

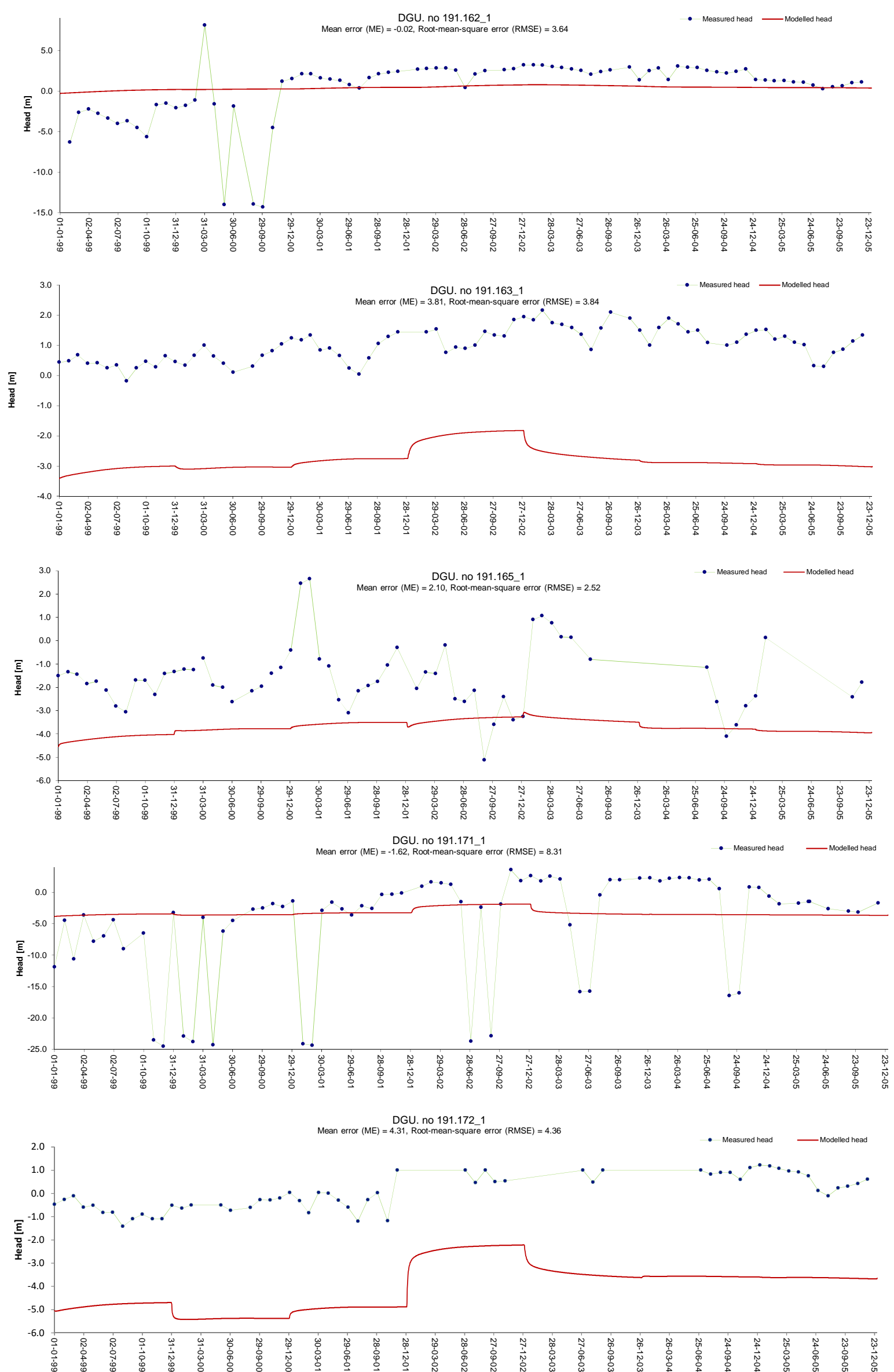

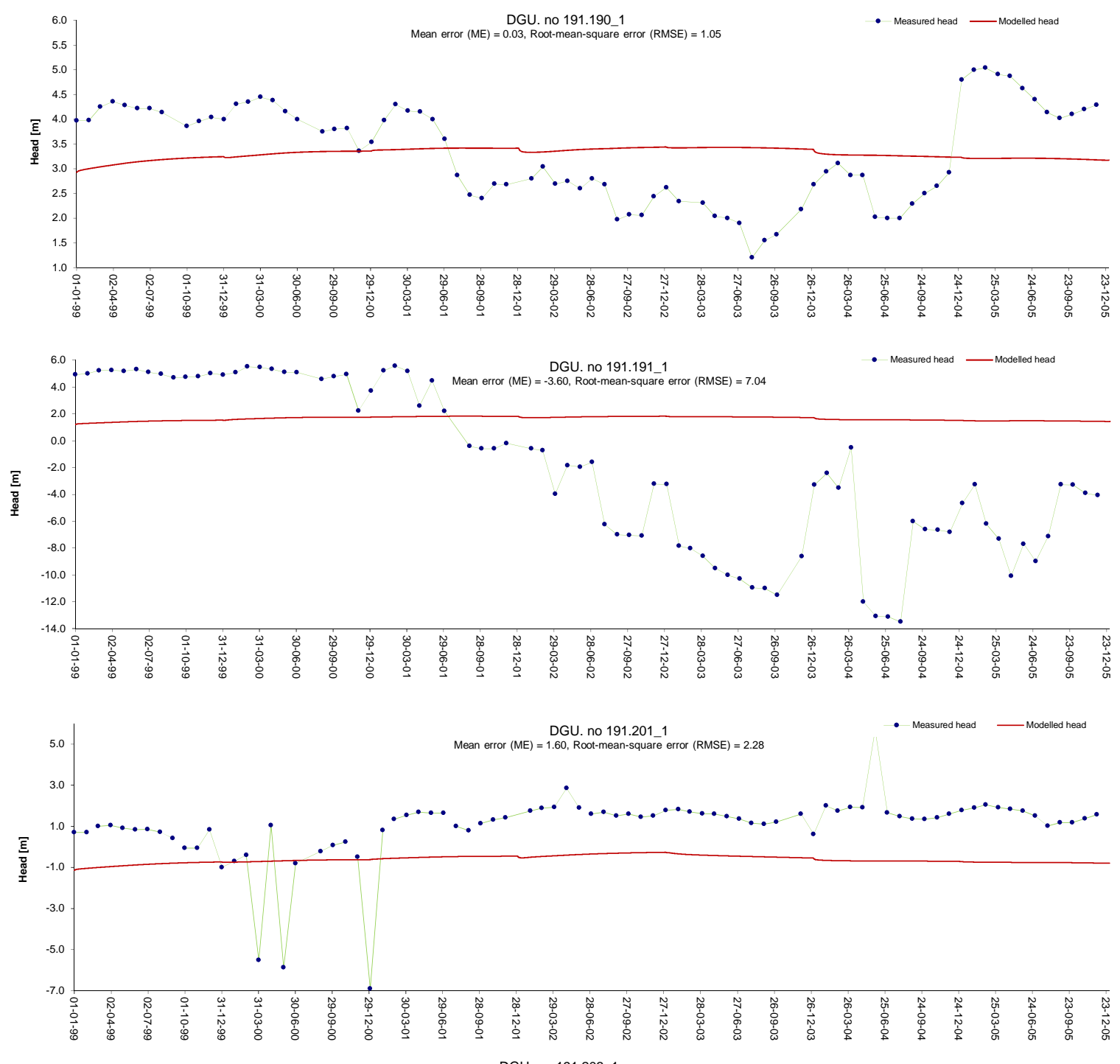

Mean error (ME) $=-1.78$, Root-mean-square
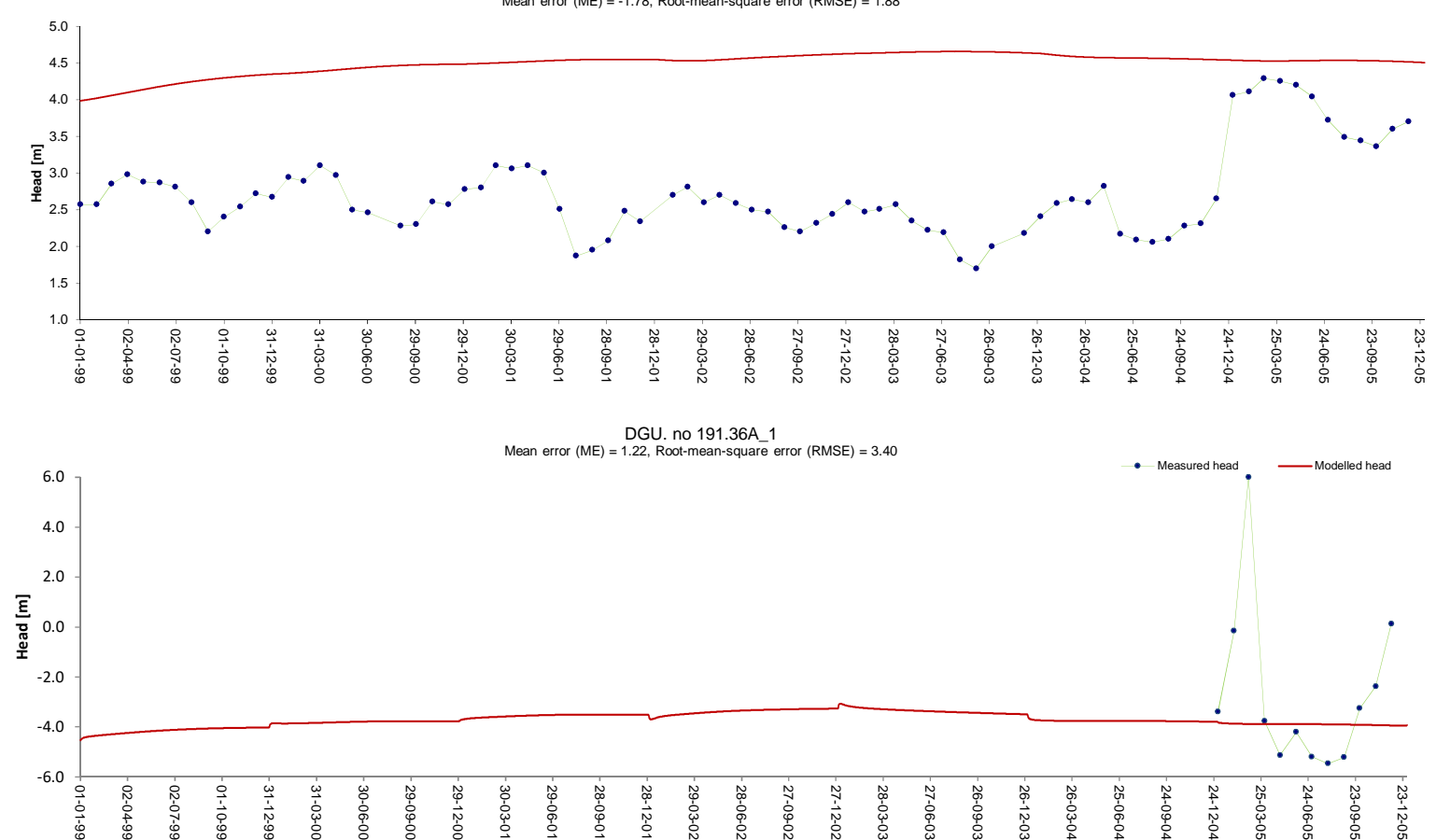

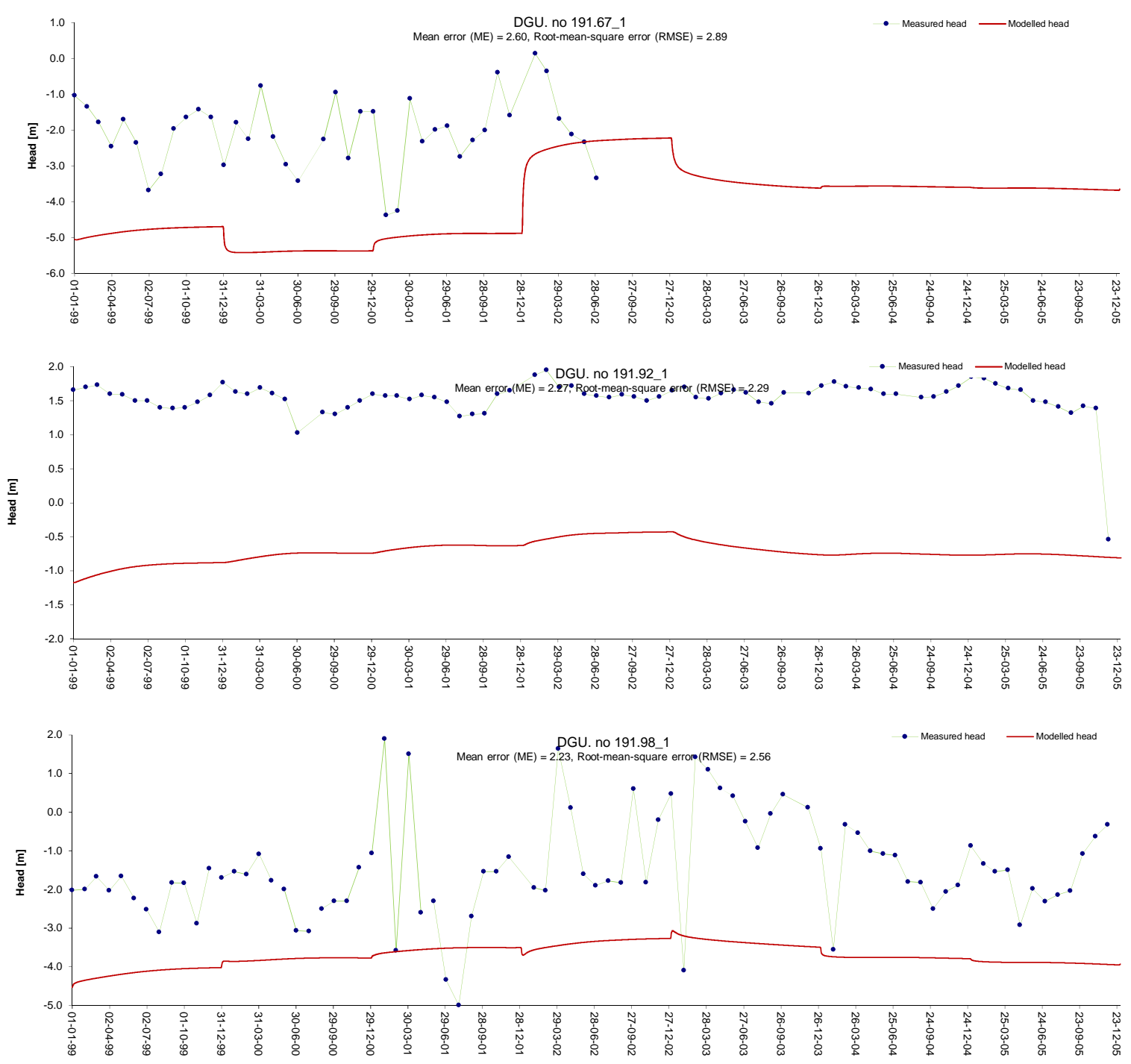

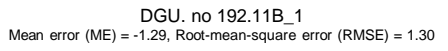
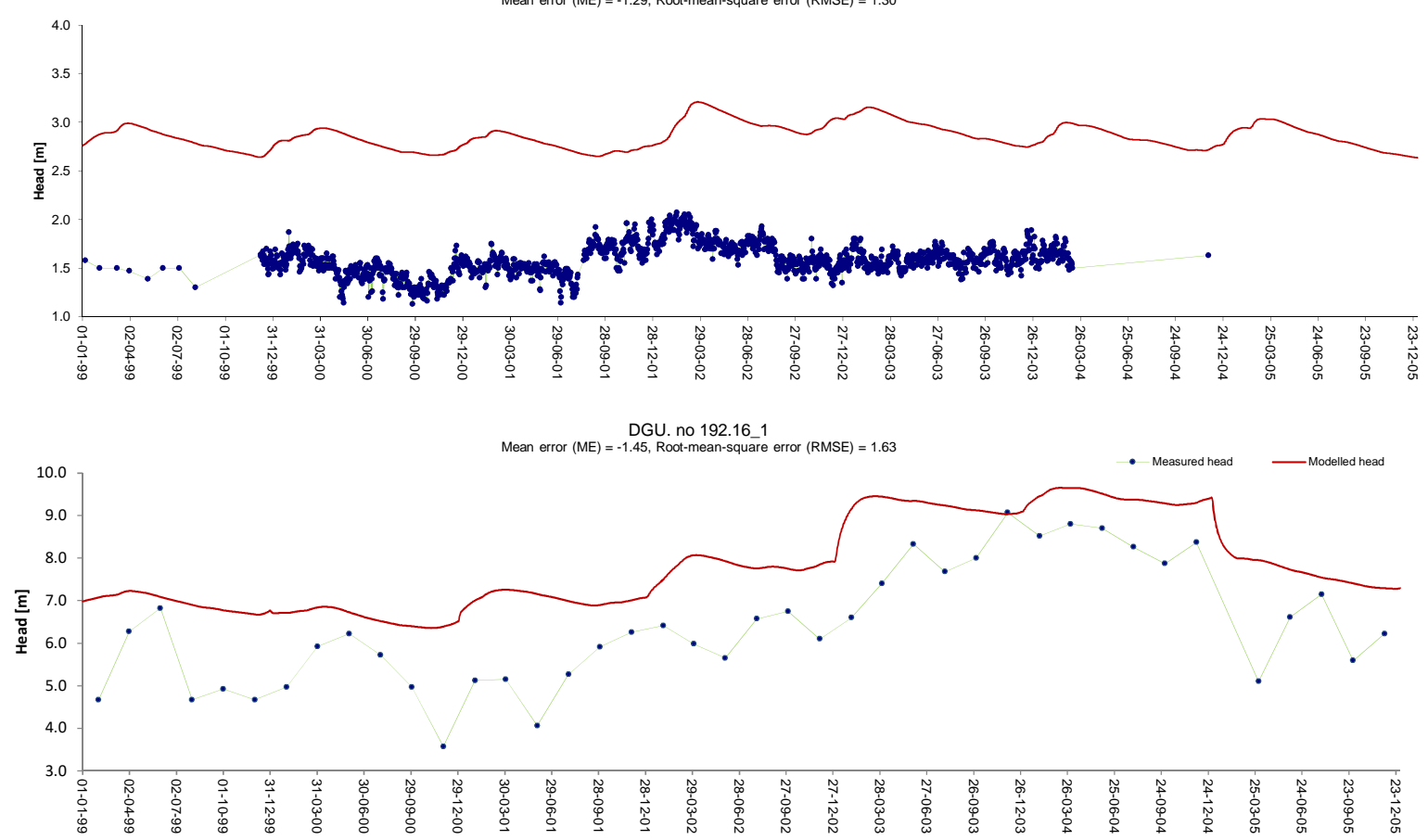

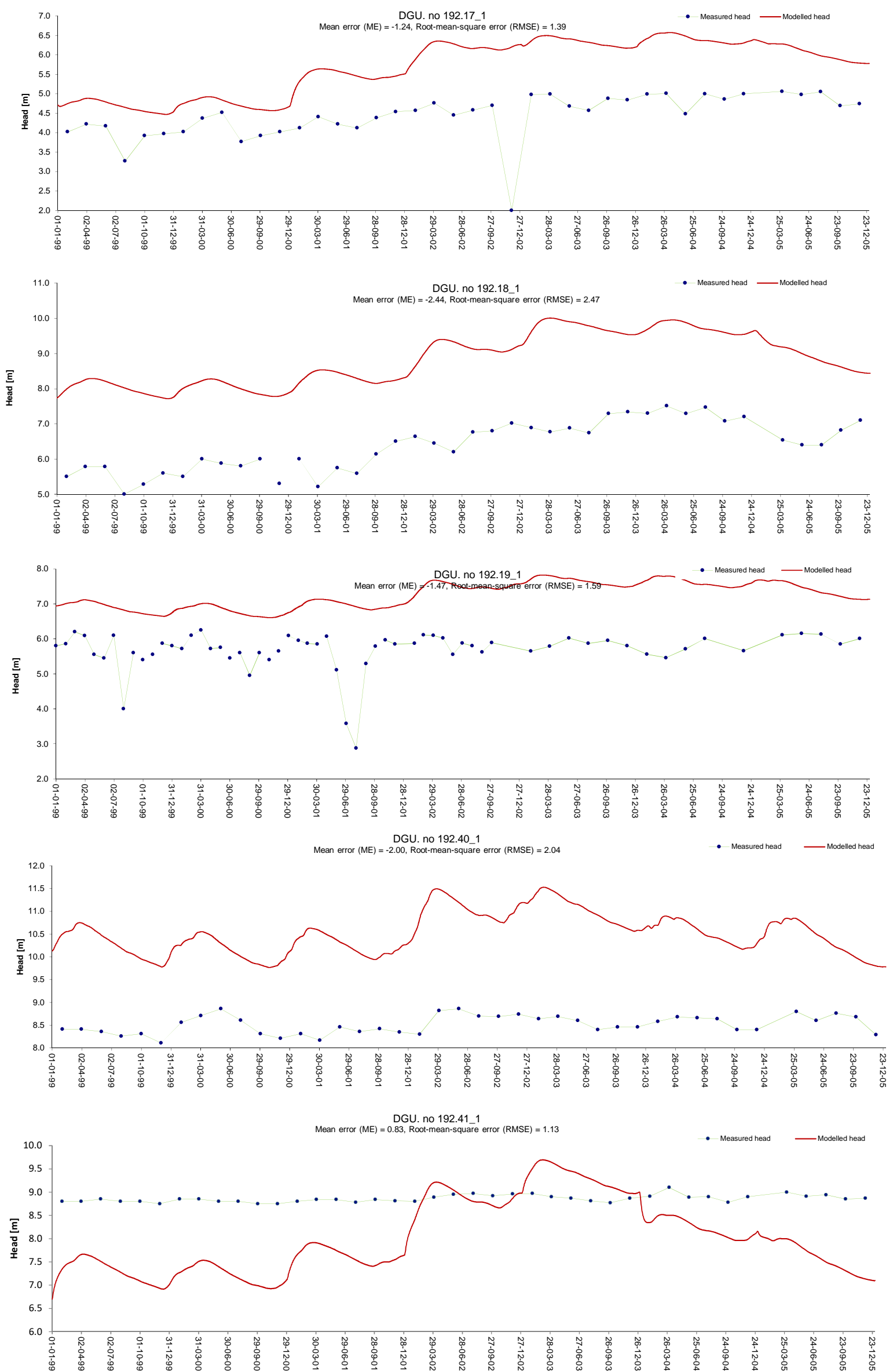

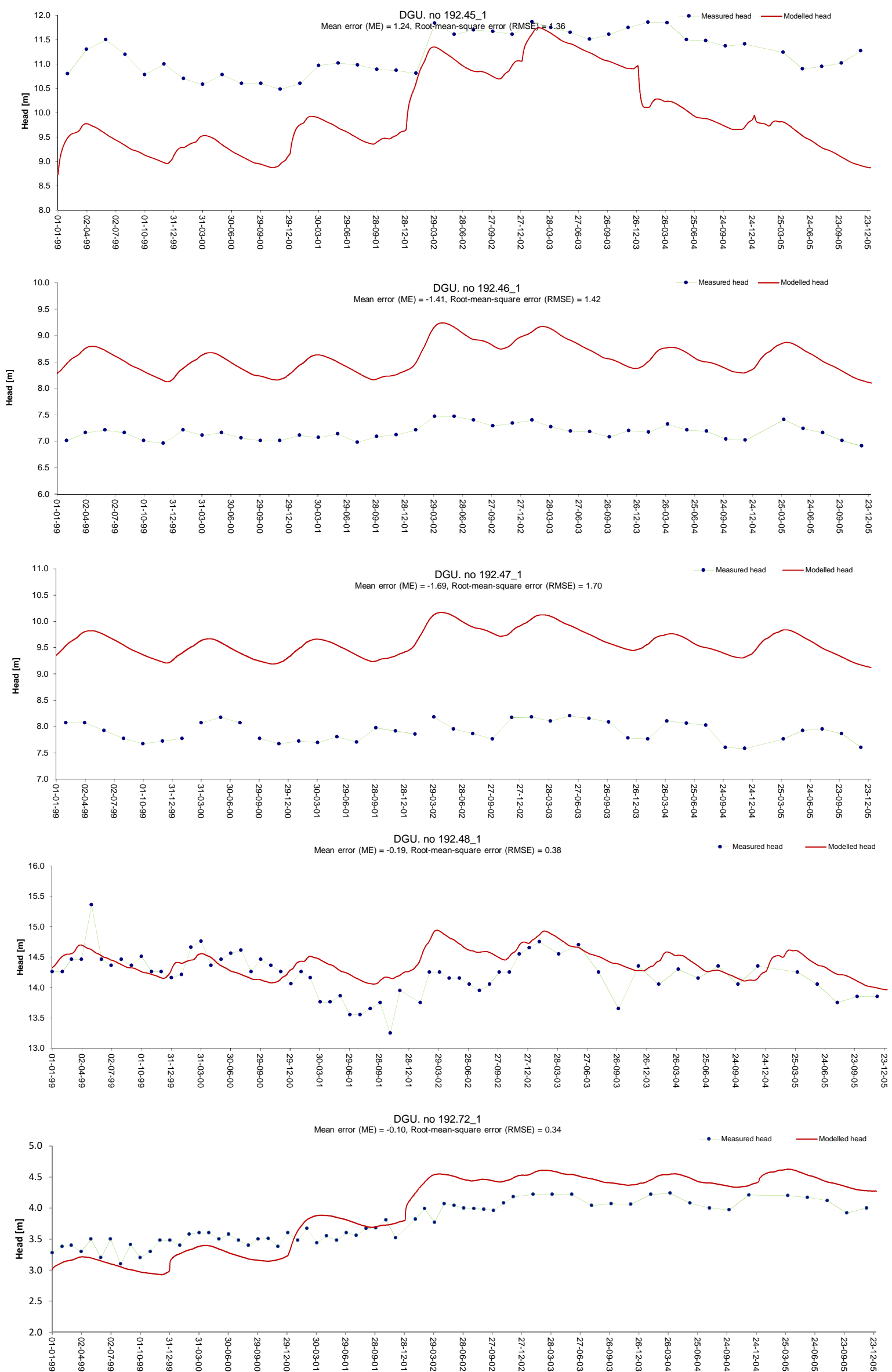

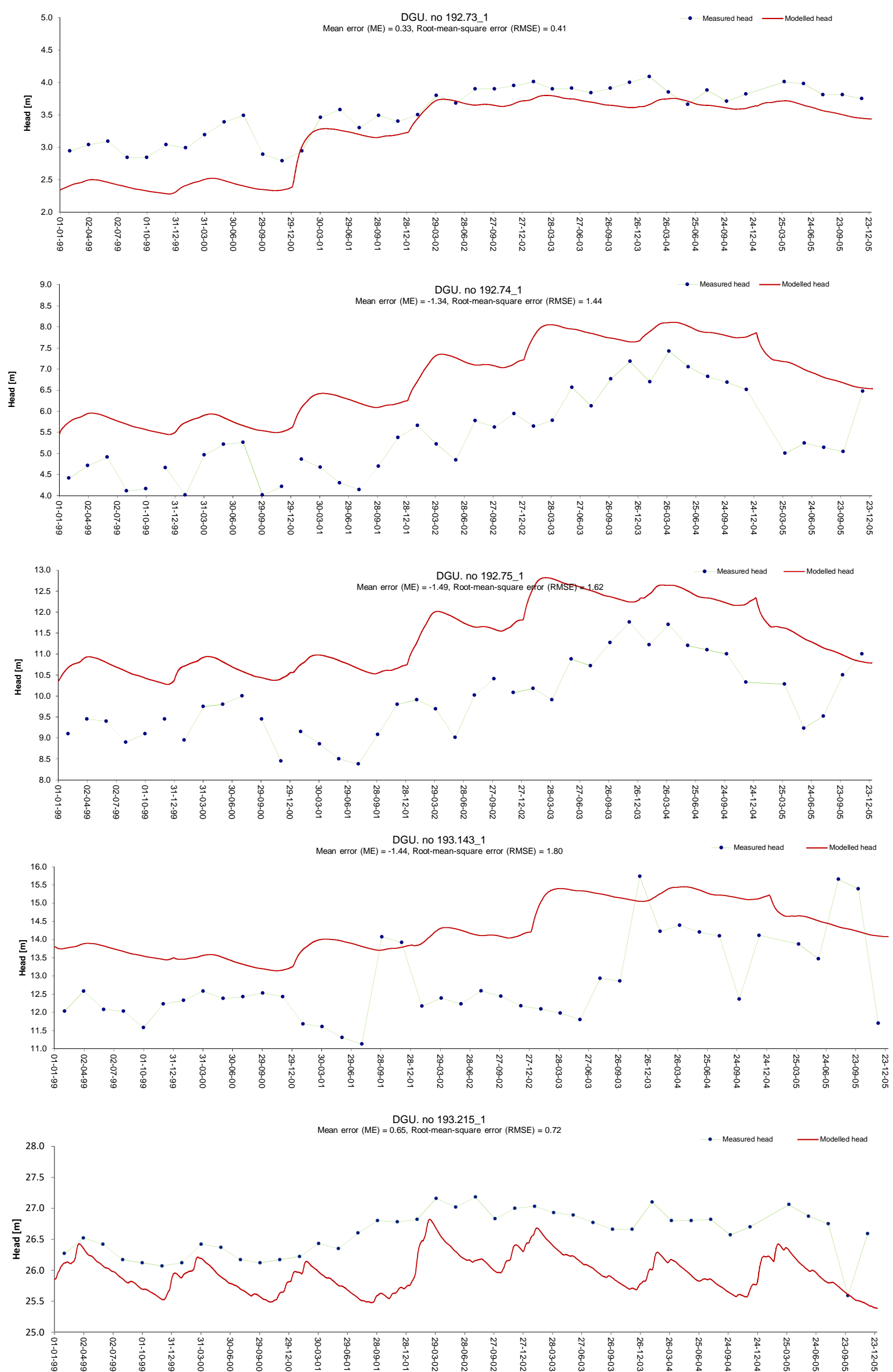

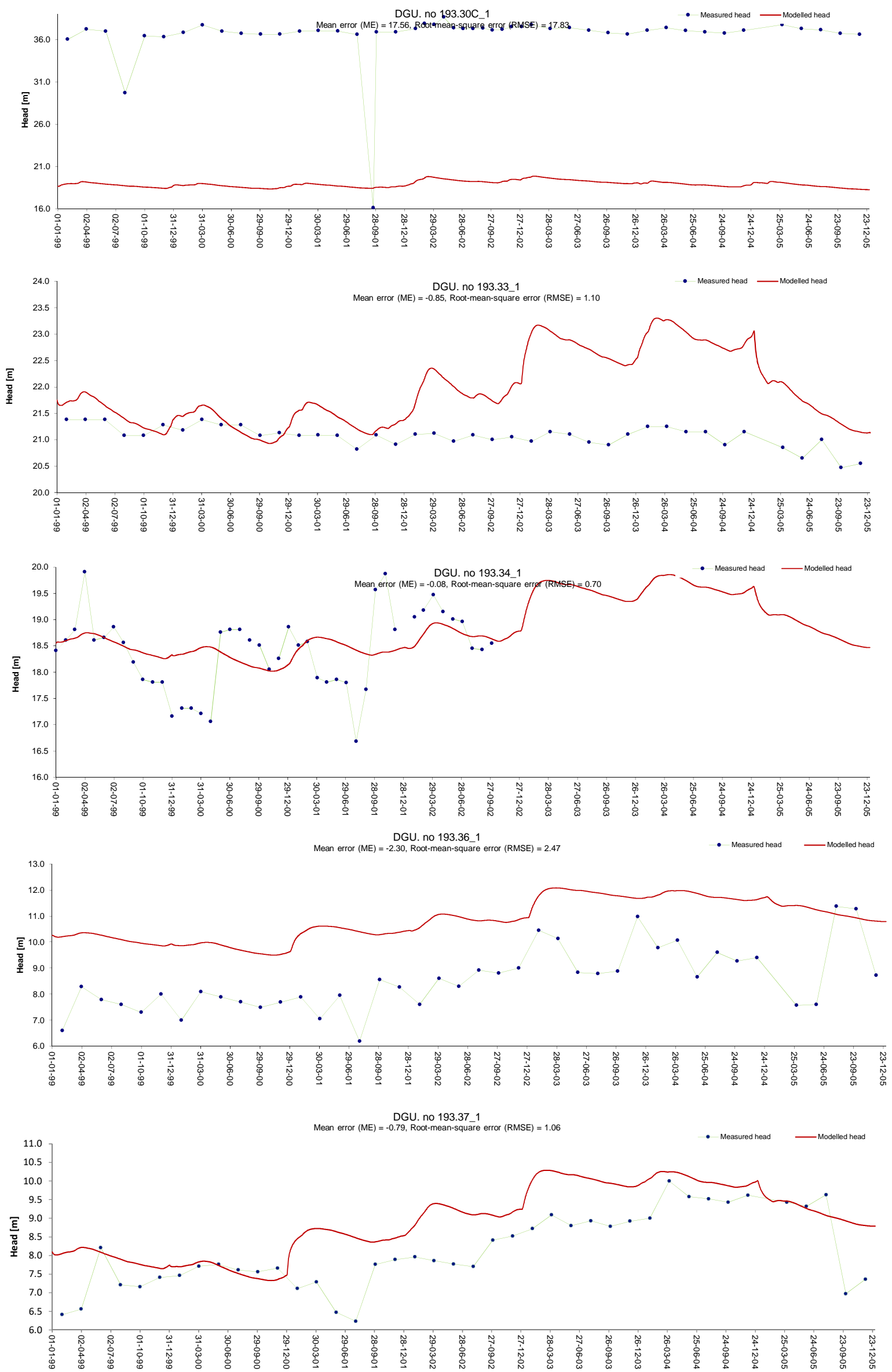

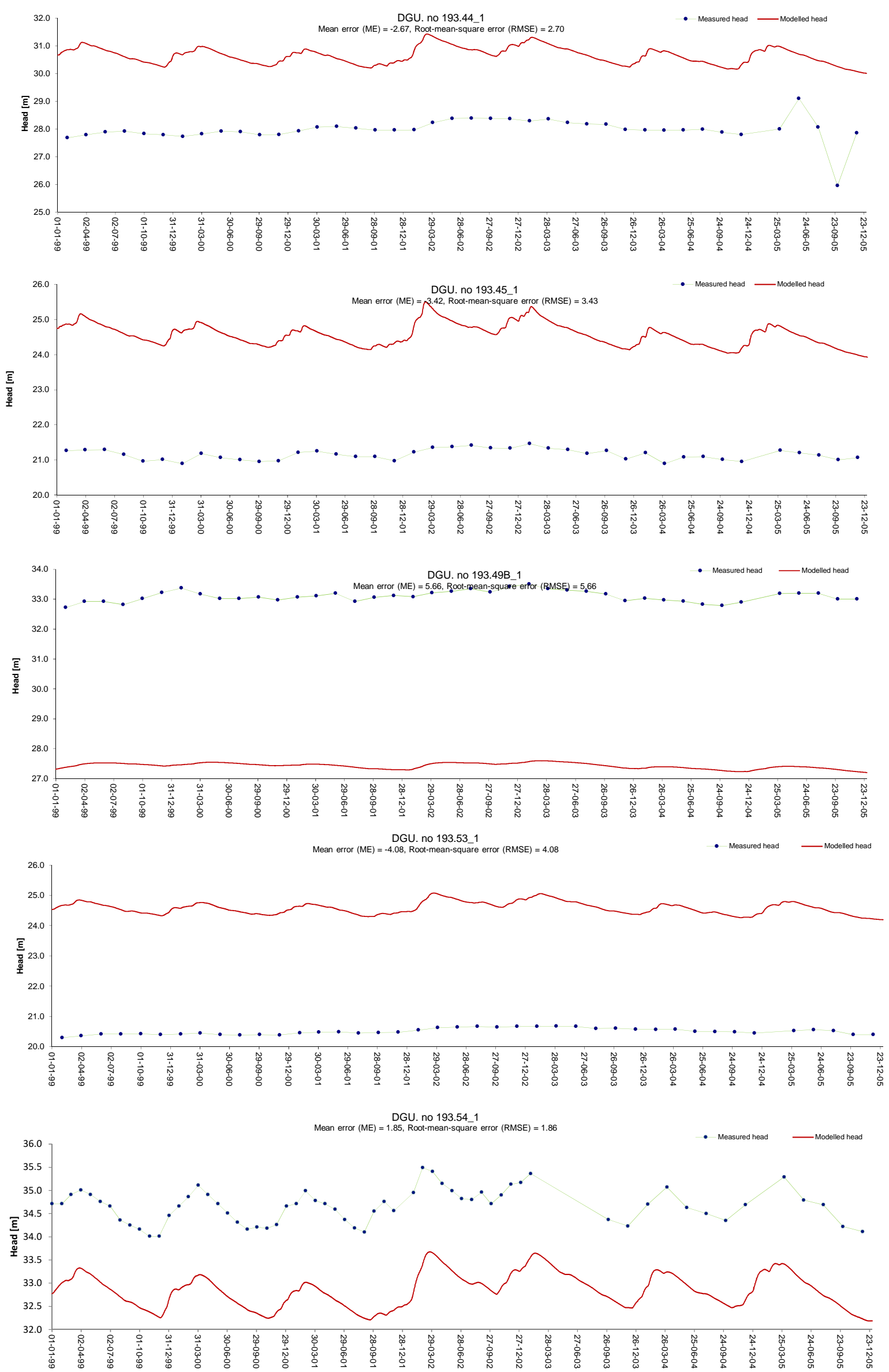

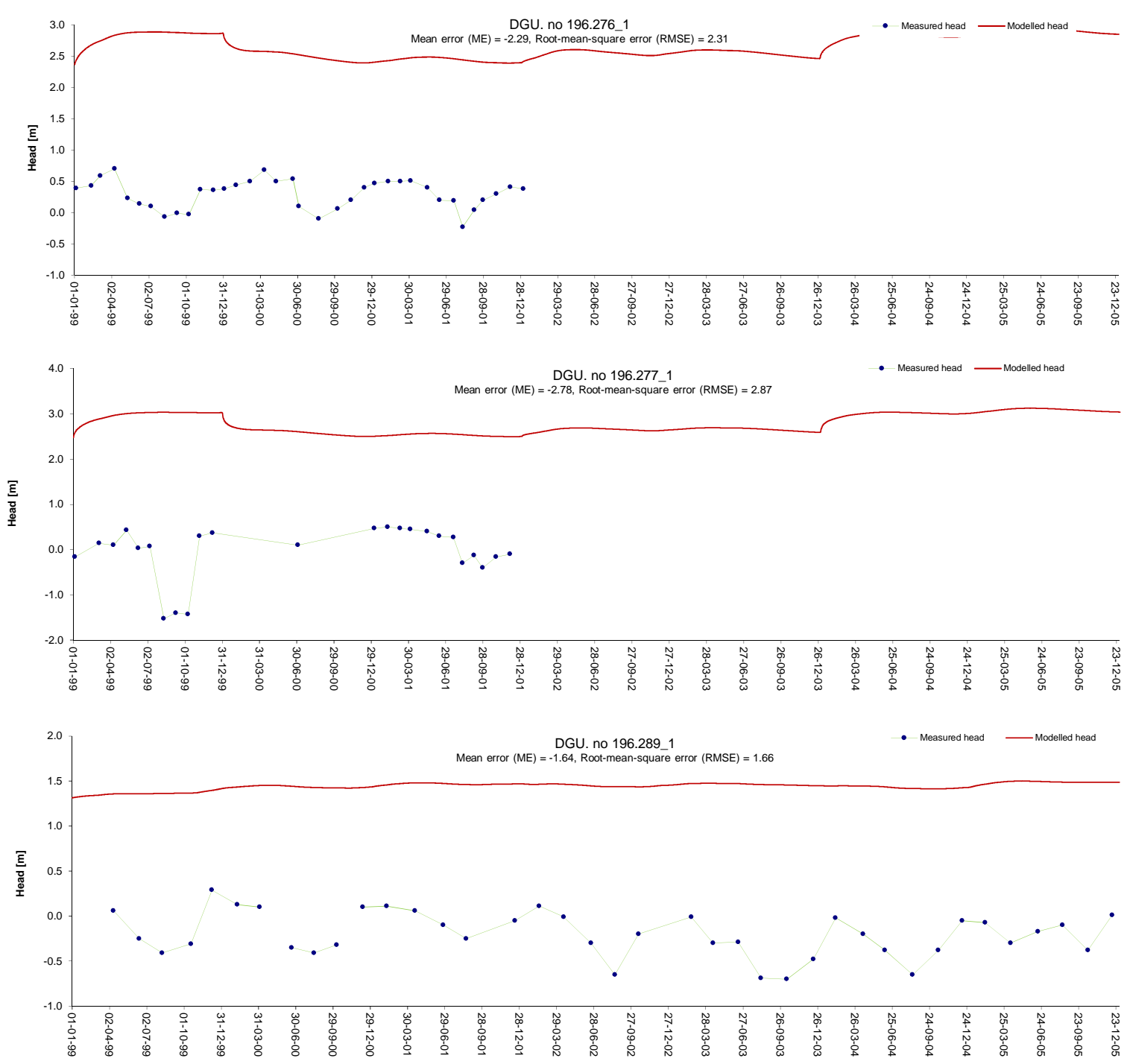

Mean error $(M E)=-2.22$. Root-mean 196.314_1

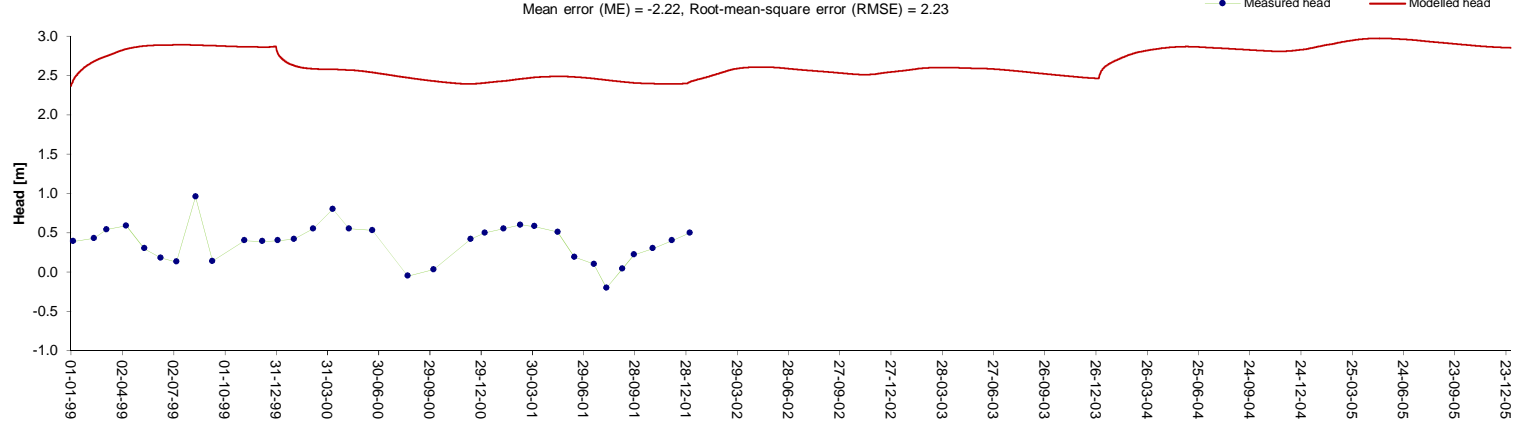

DGU. no 196.316_1
Mean error (ME) $=25.34$, Root-mean-square error (RMSE) $=25.56$

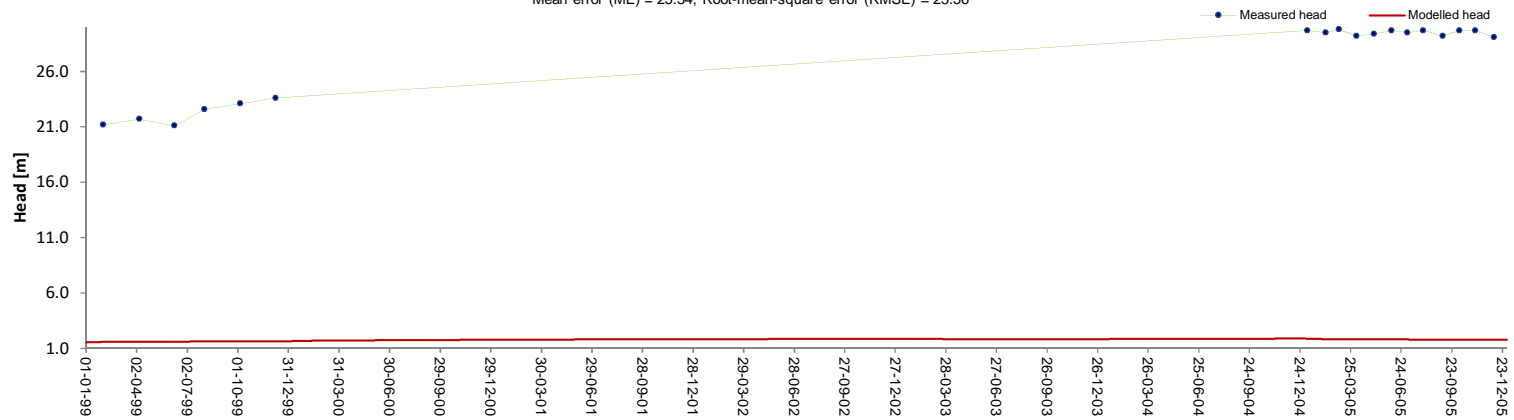



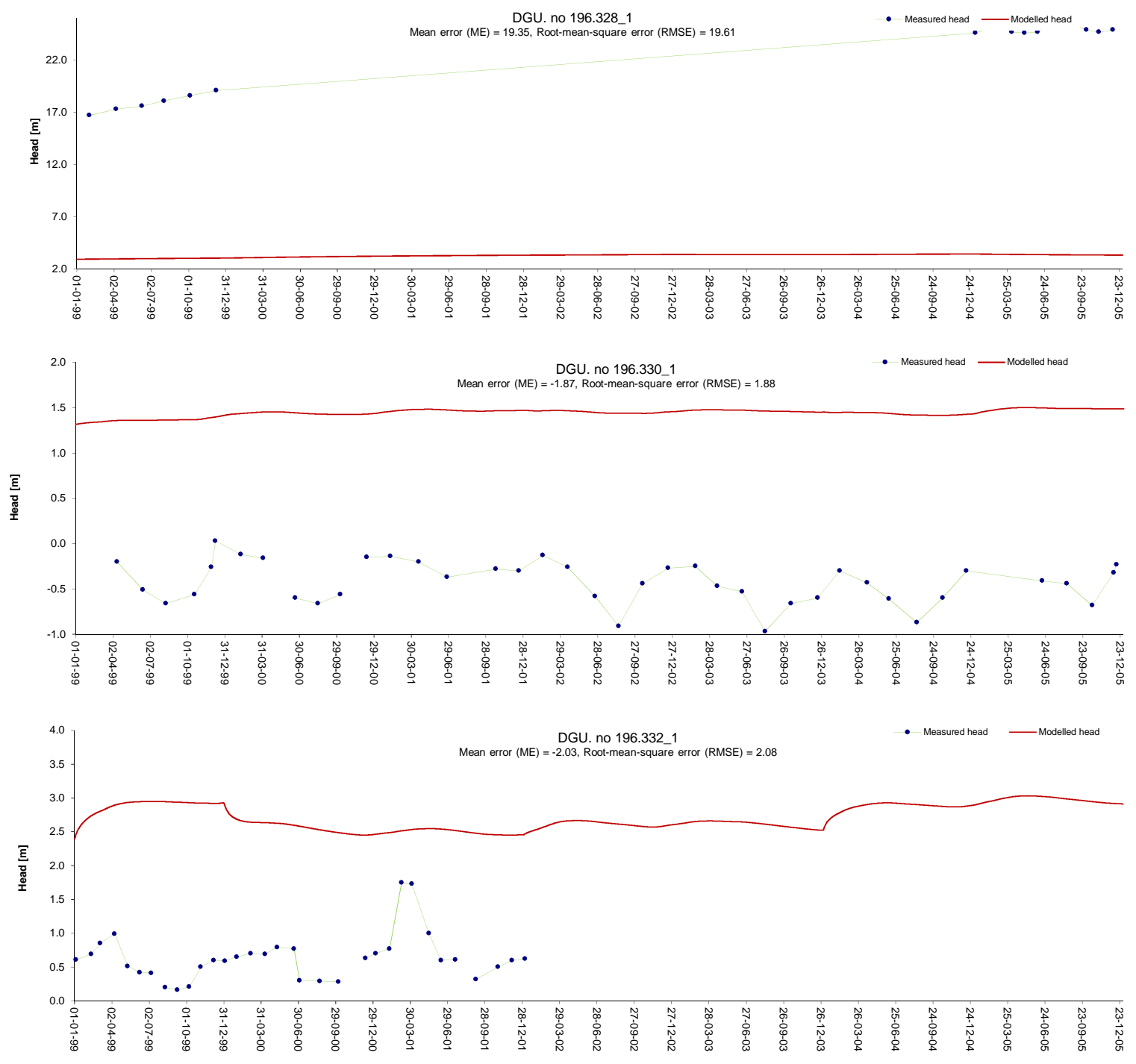

DGU. no 196.335
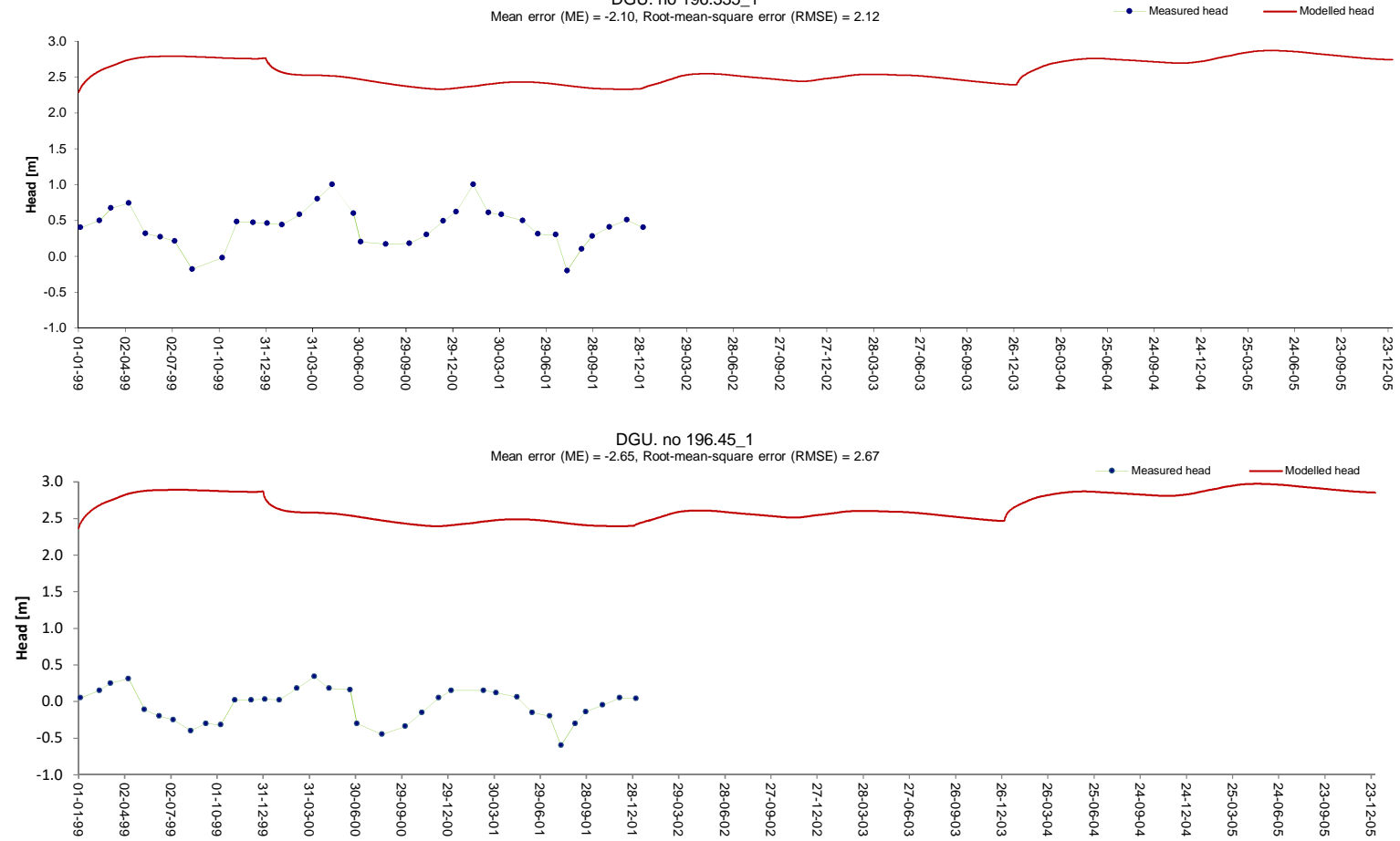

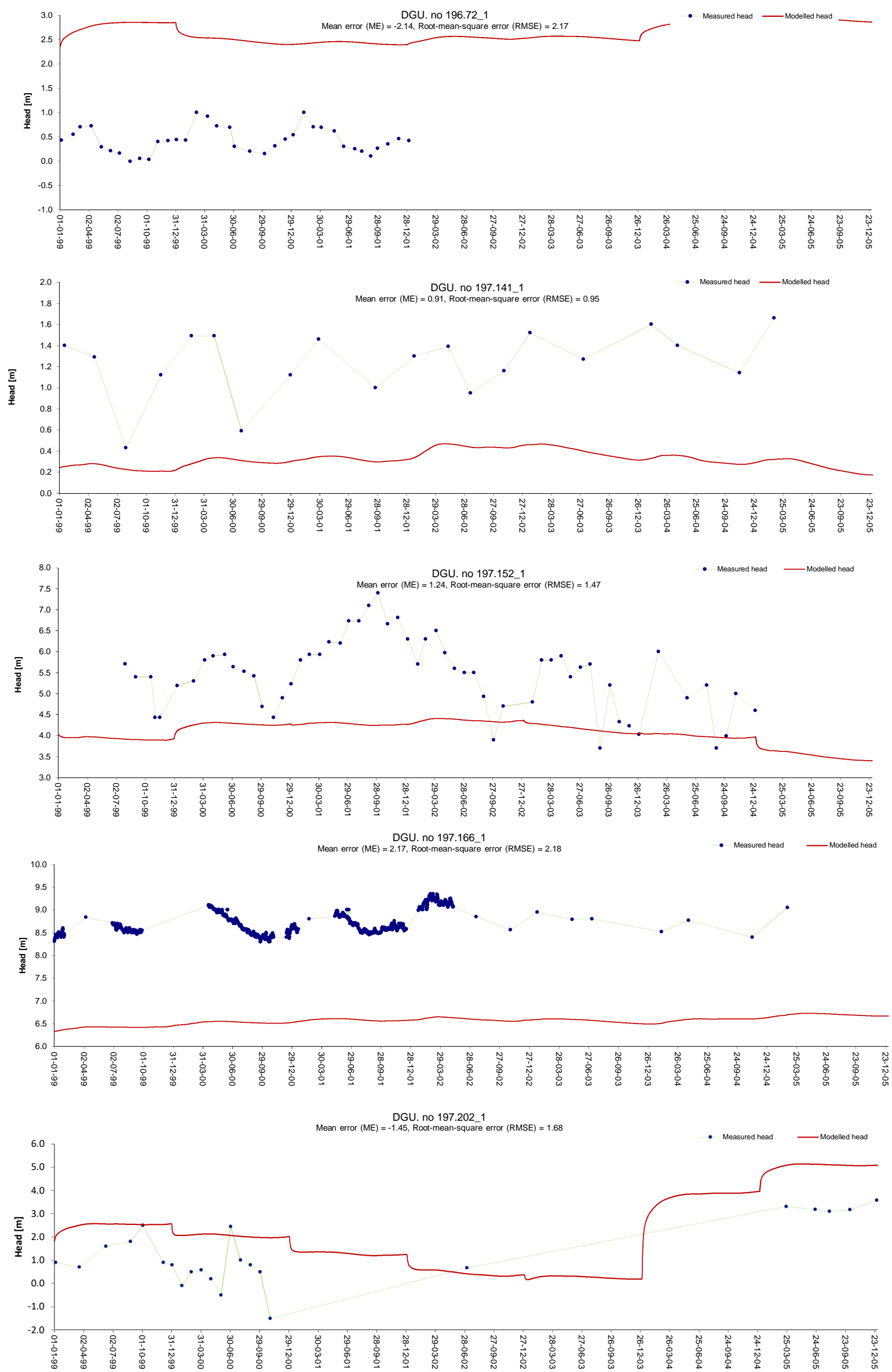

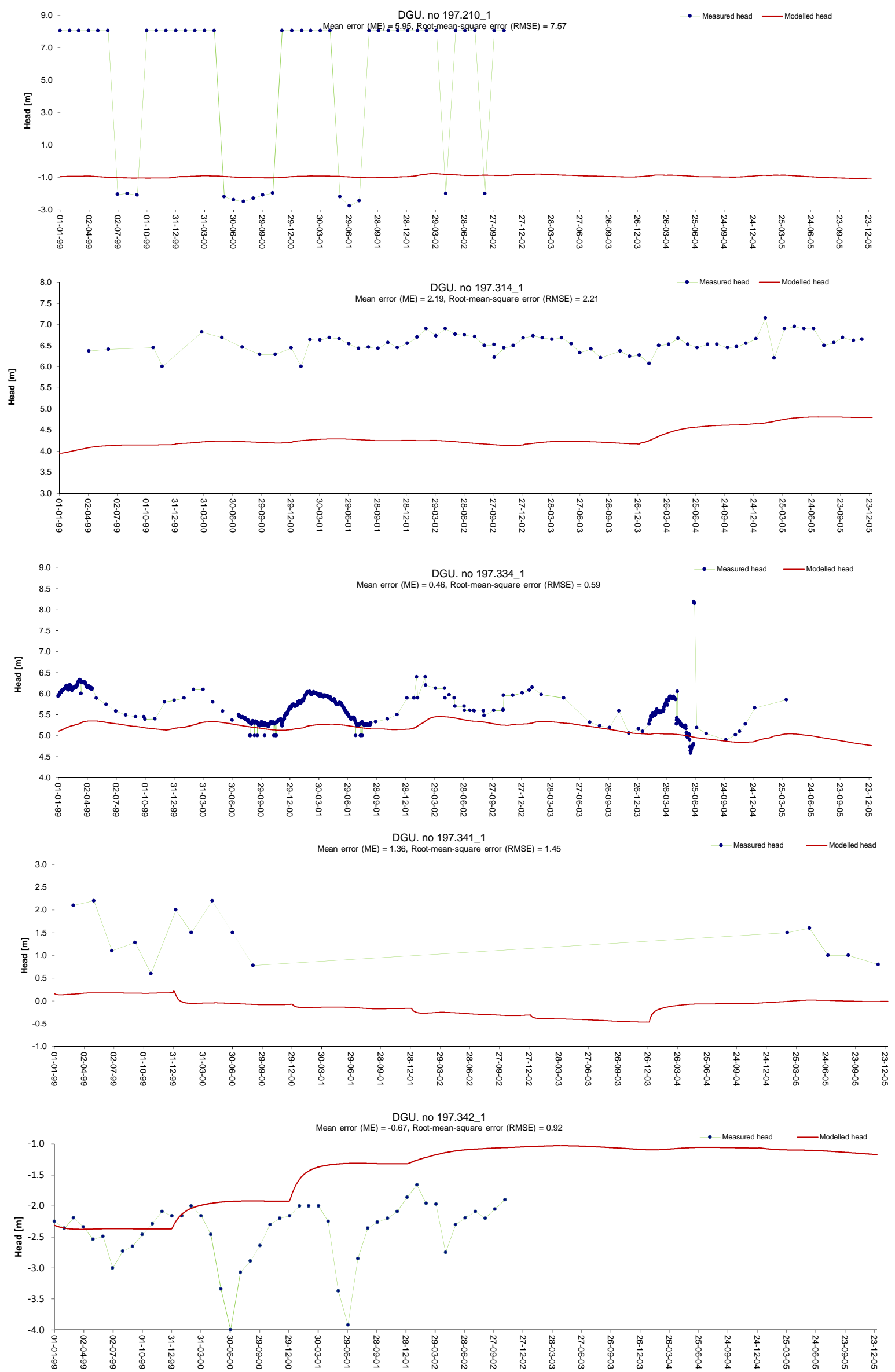

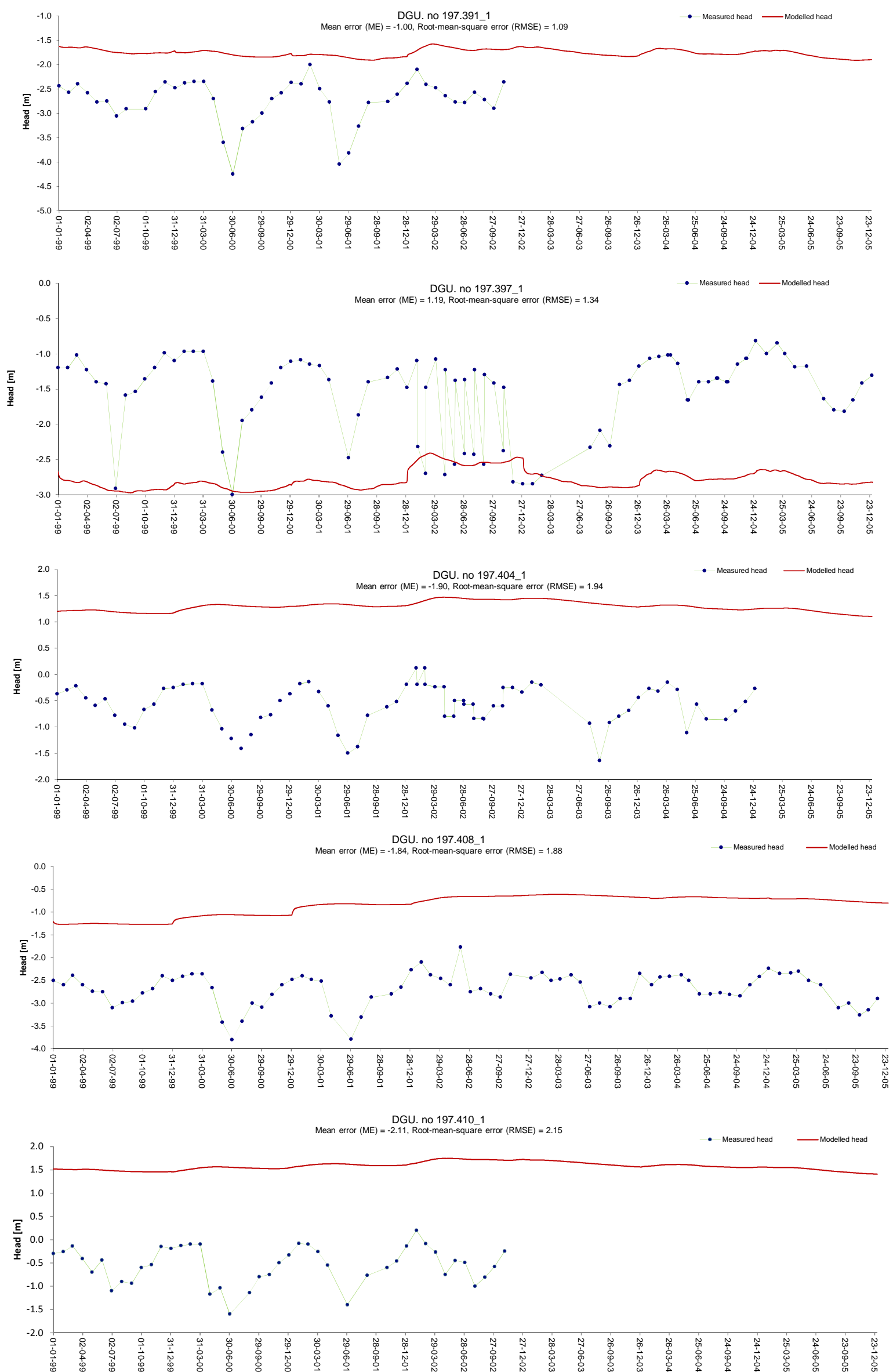

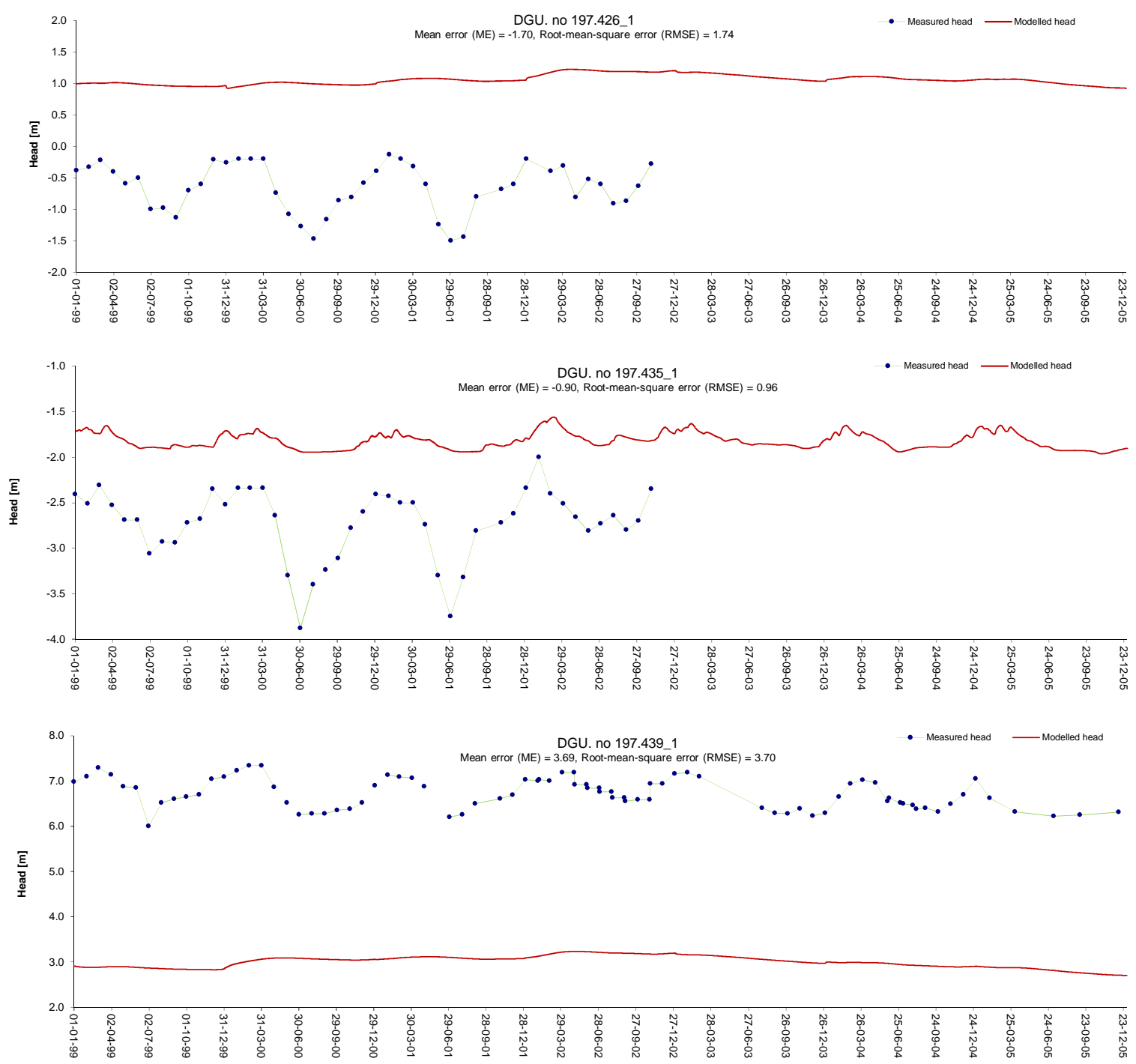

Mean error (ME) $=0.79$, Root-mean-4949
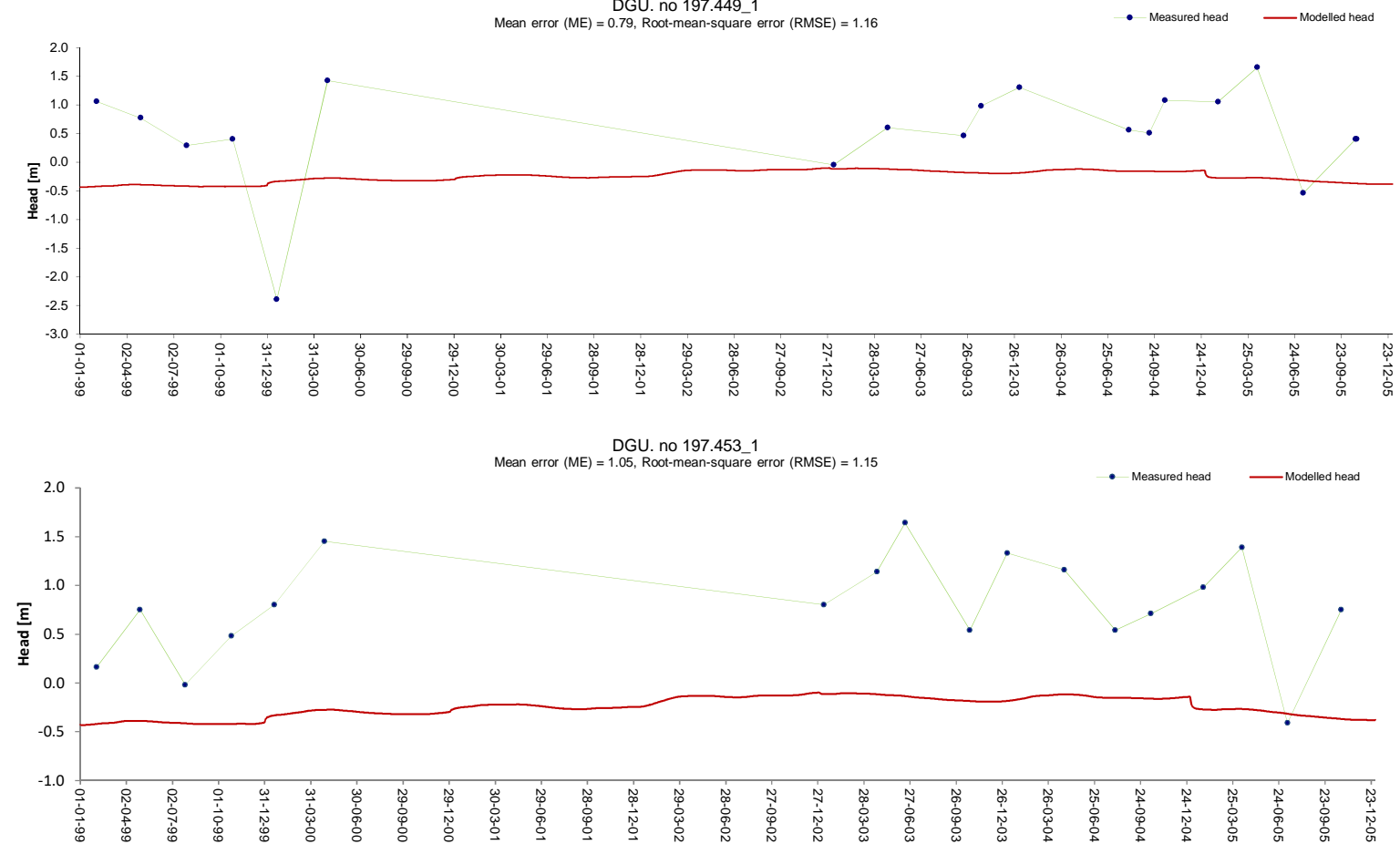

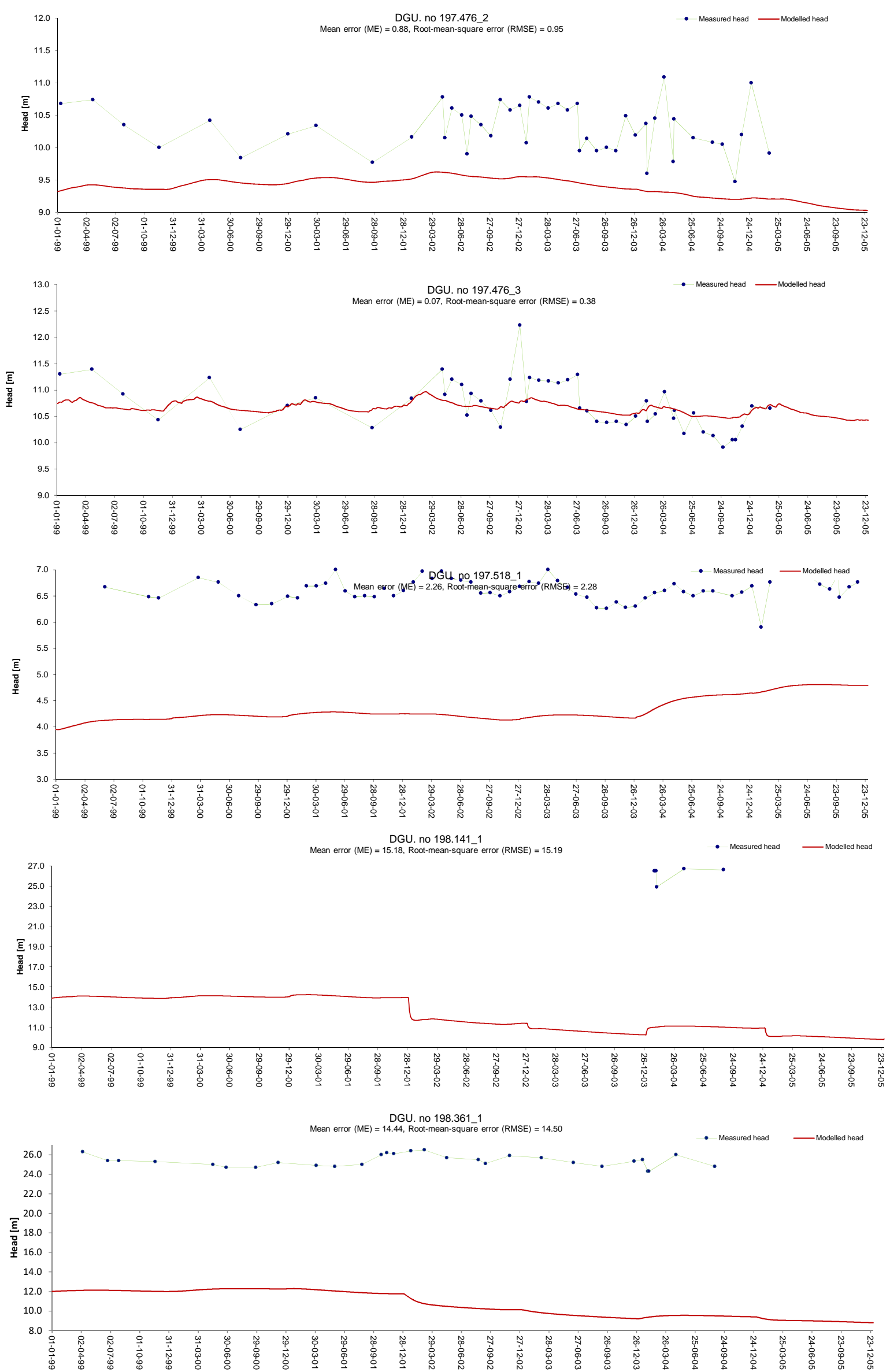

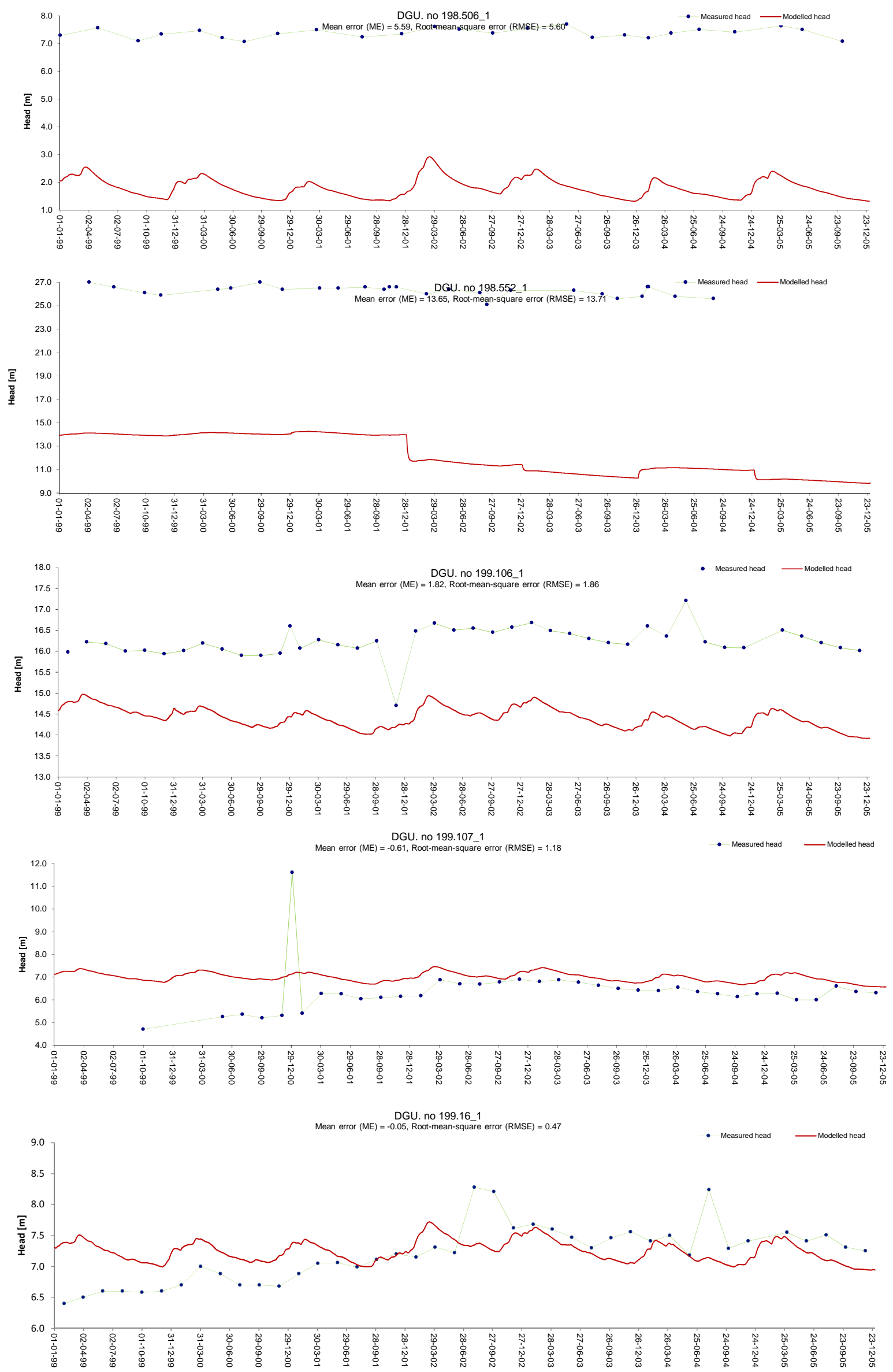

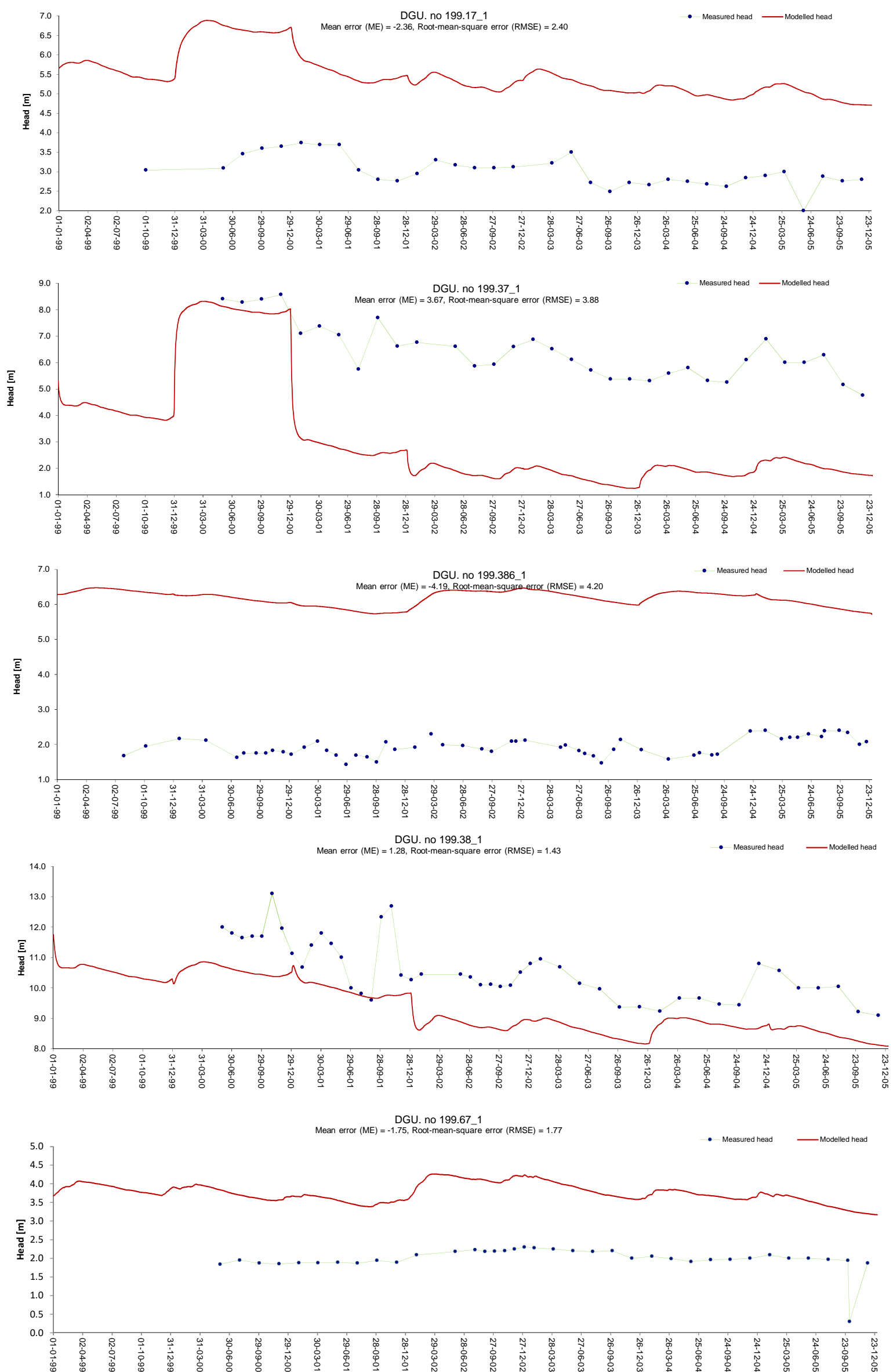

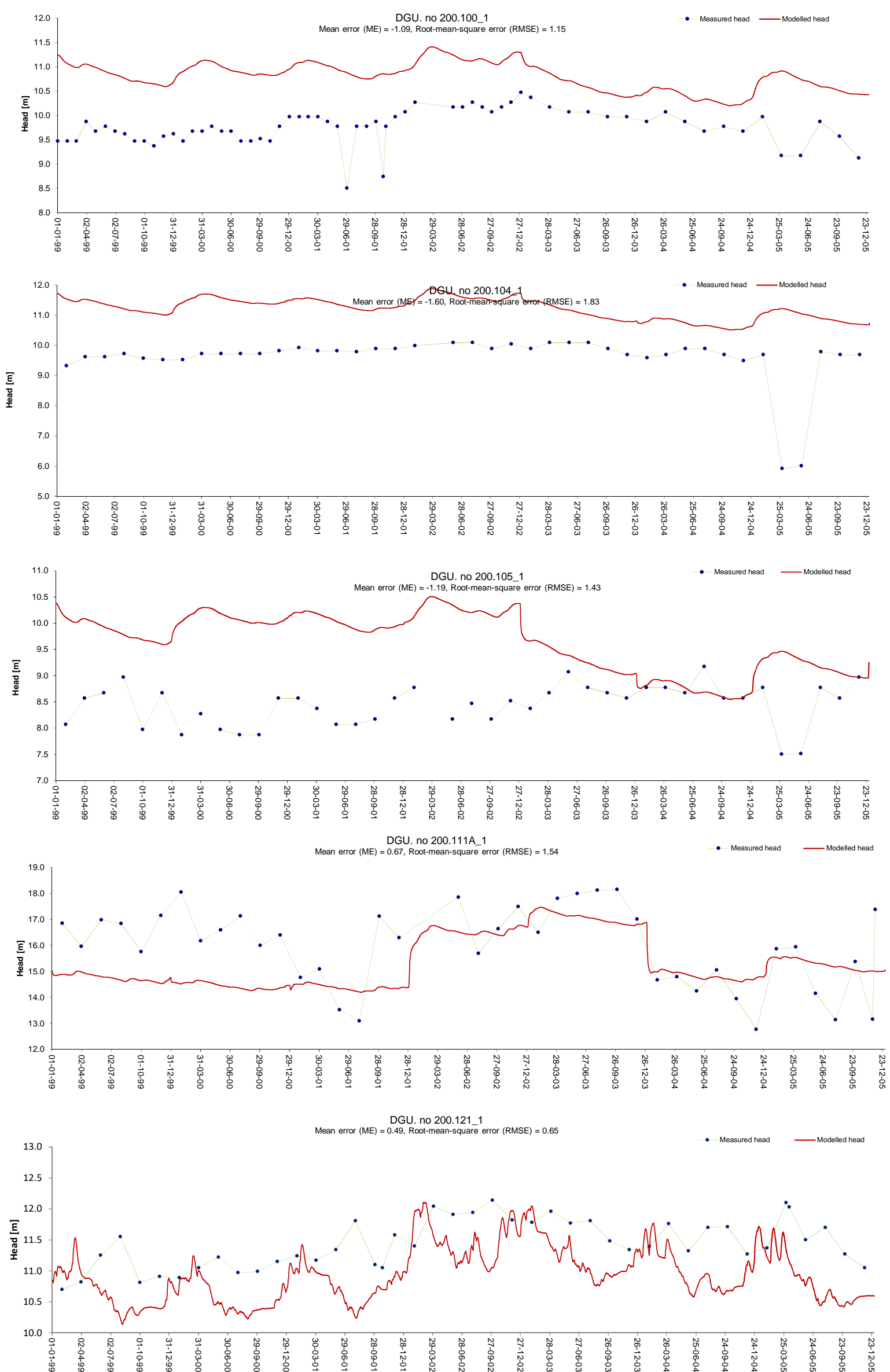

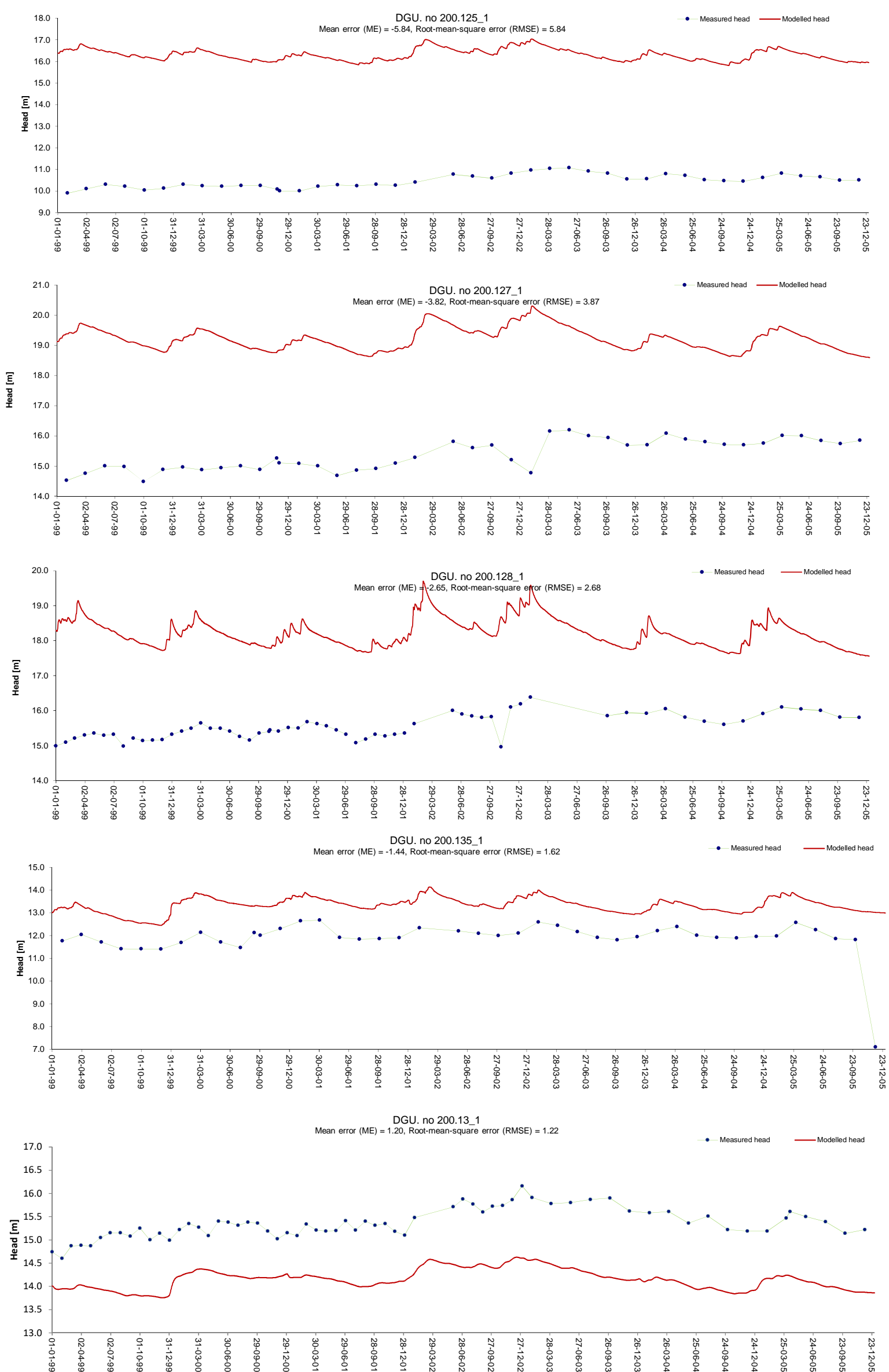

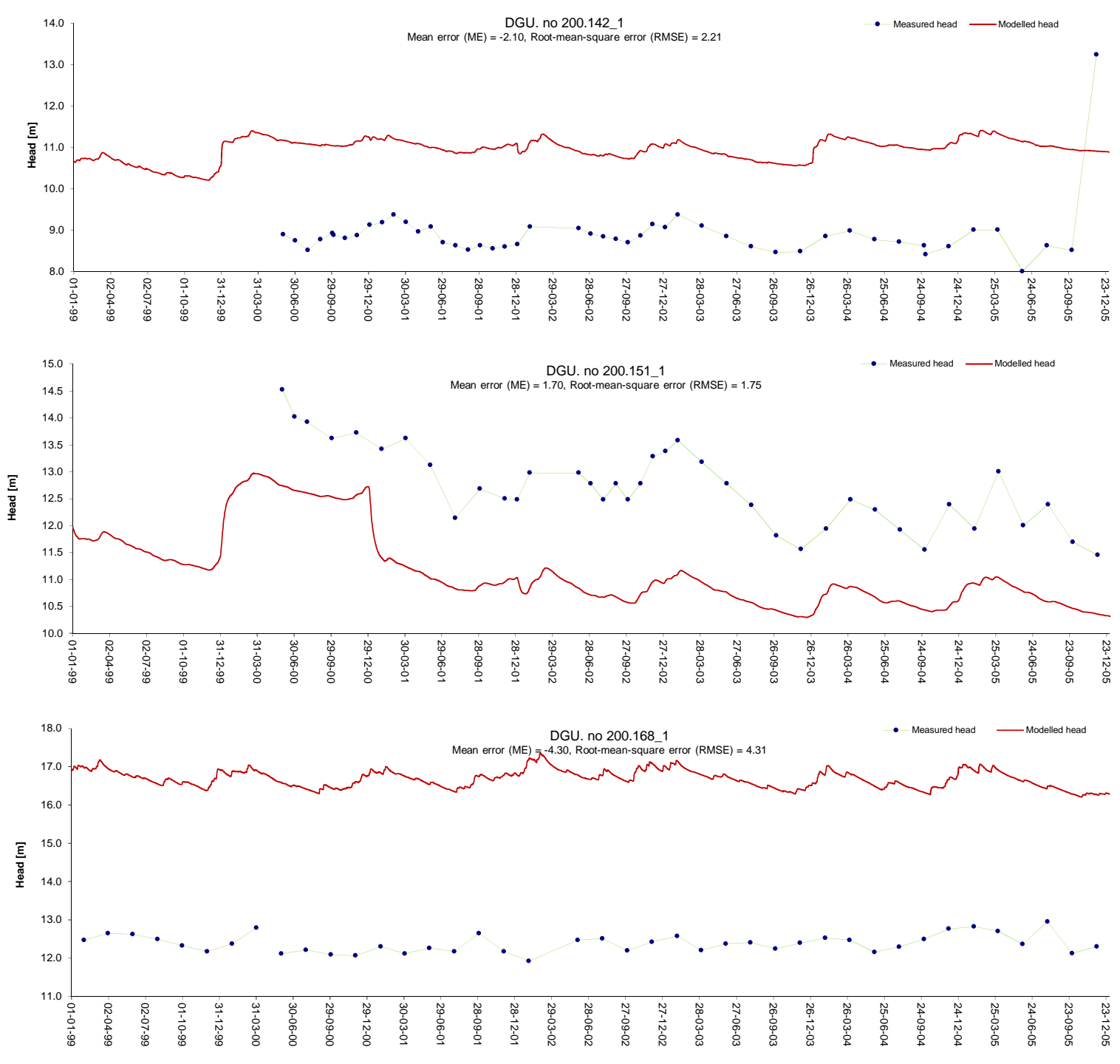
DGU. no $200.170 \_1$
Mean error (ME) $=-1.93$, Root-mean-square error (RMSE) $=1.96$
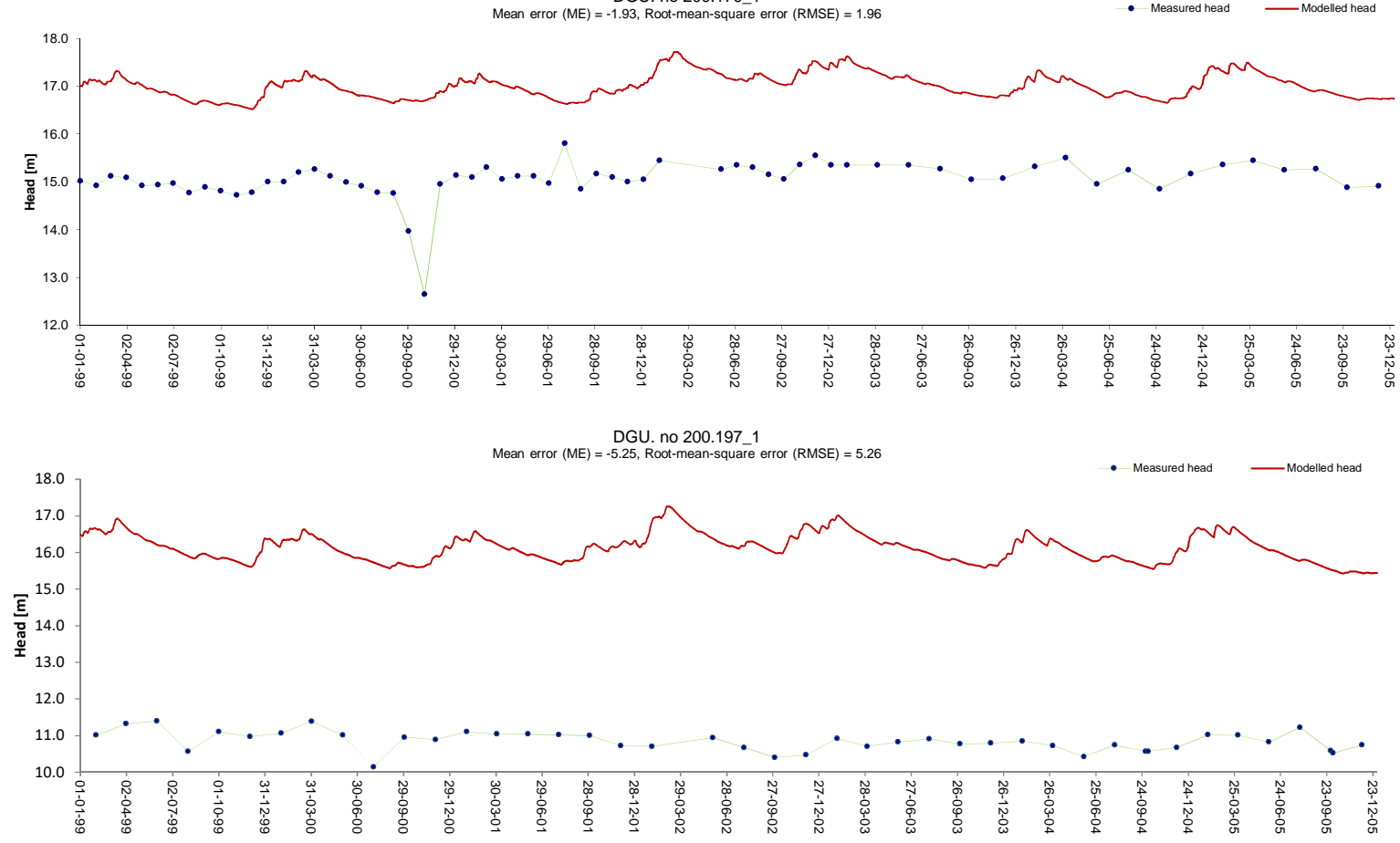

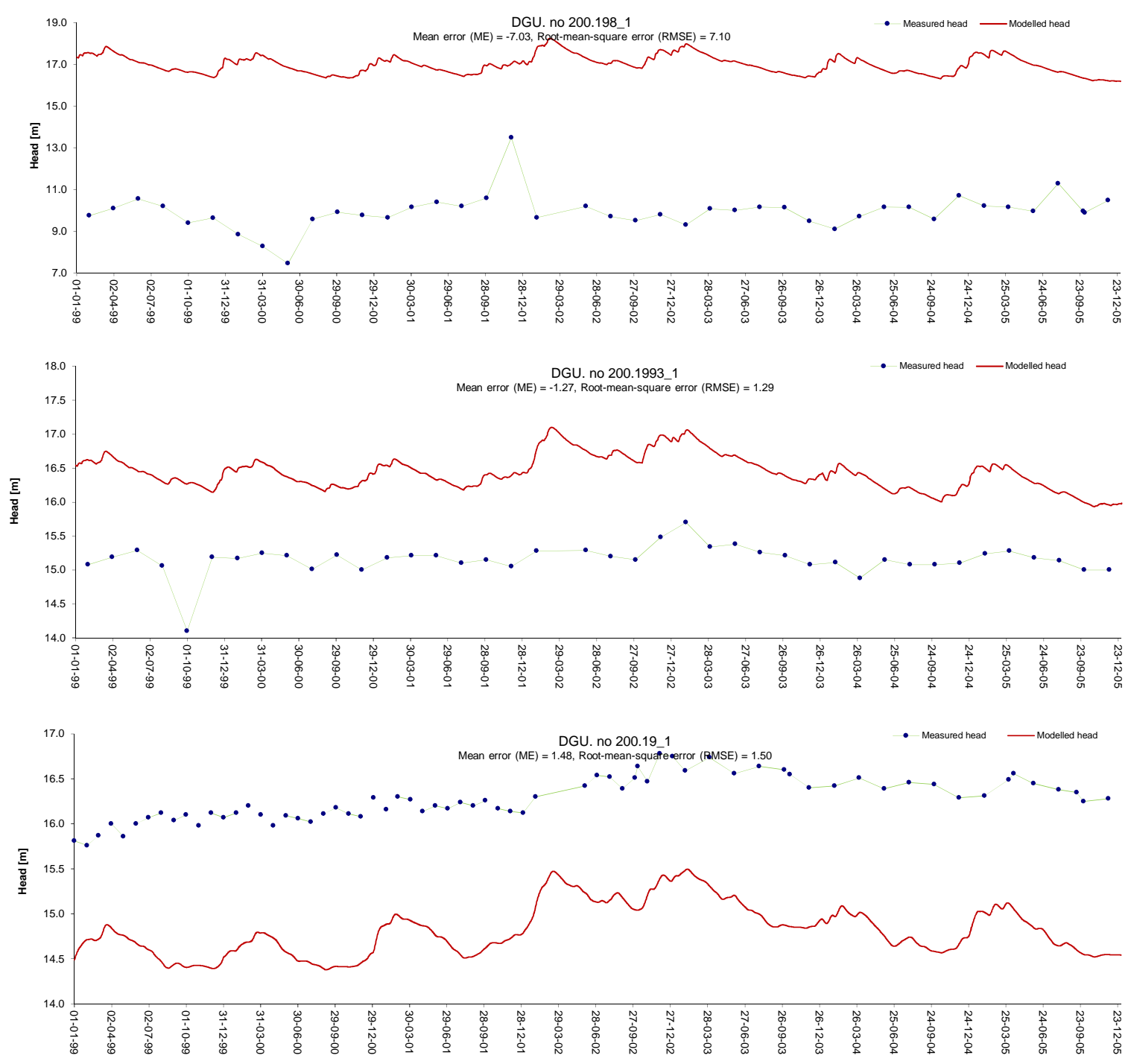

DGU. no 200.209
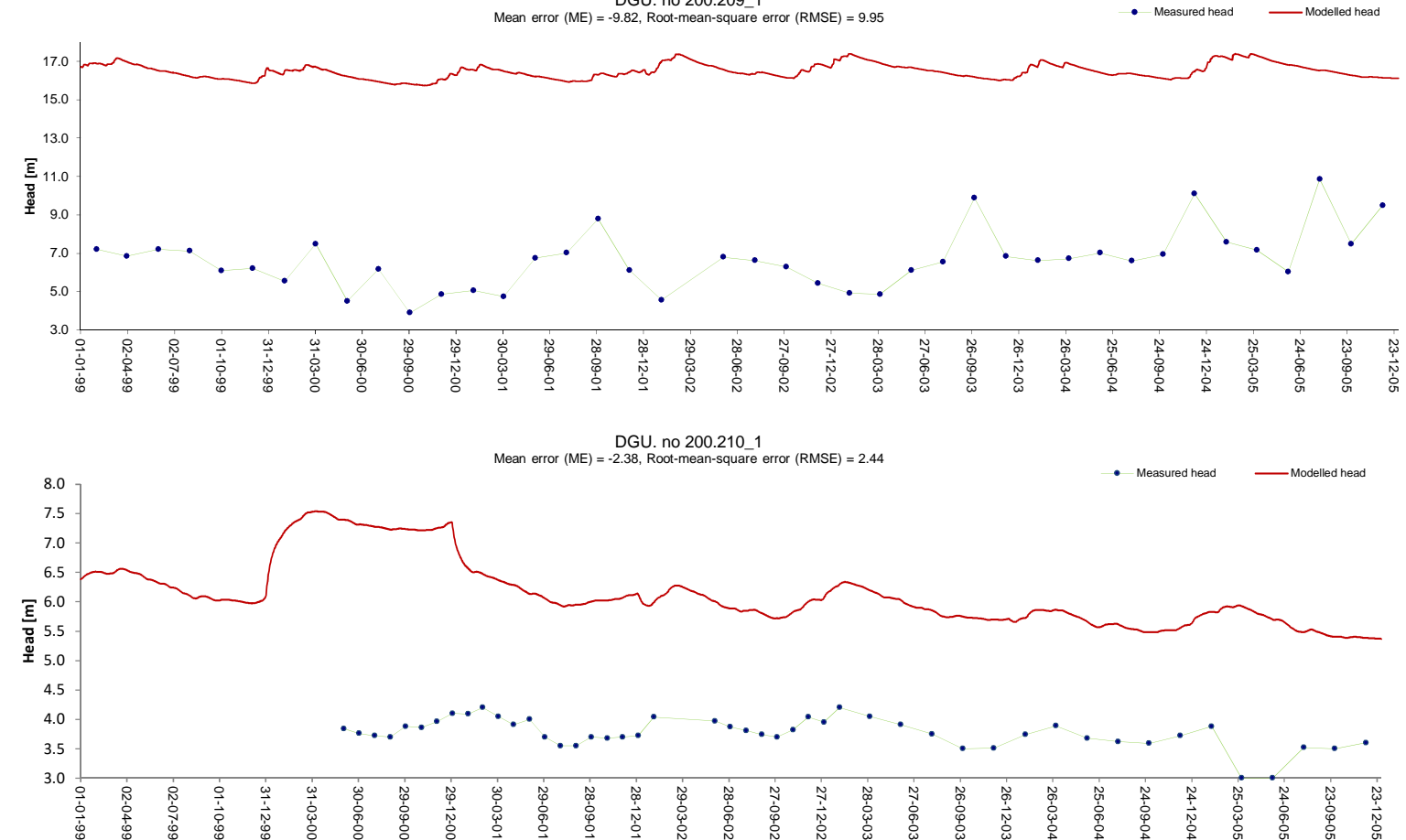

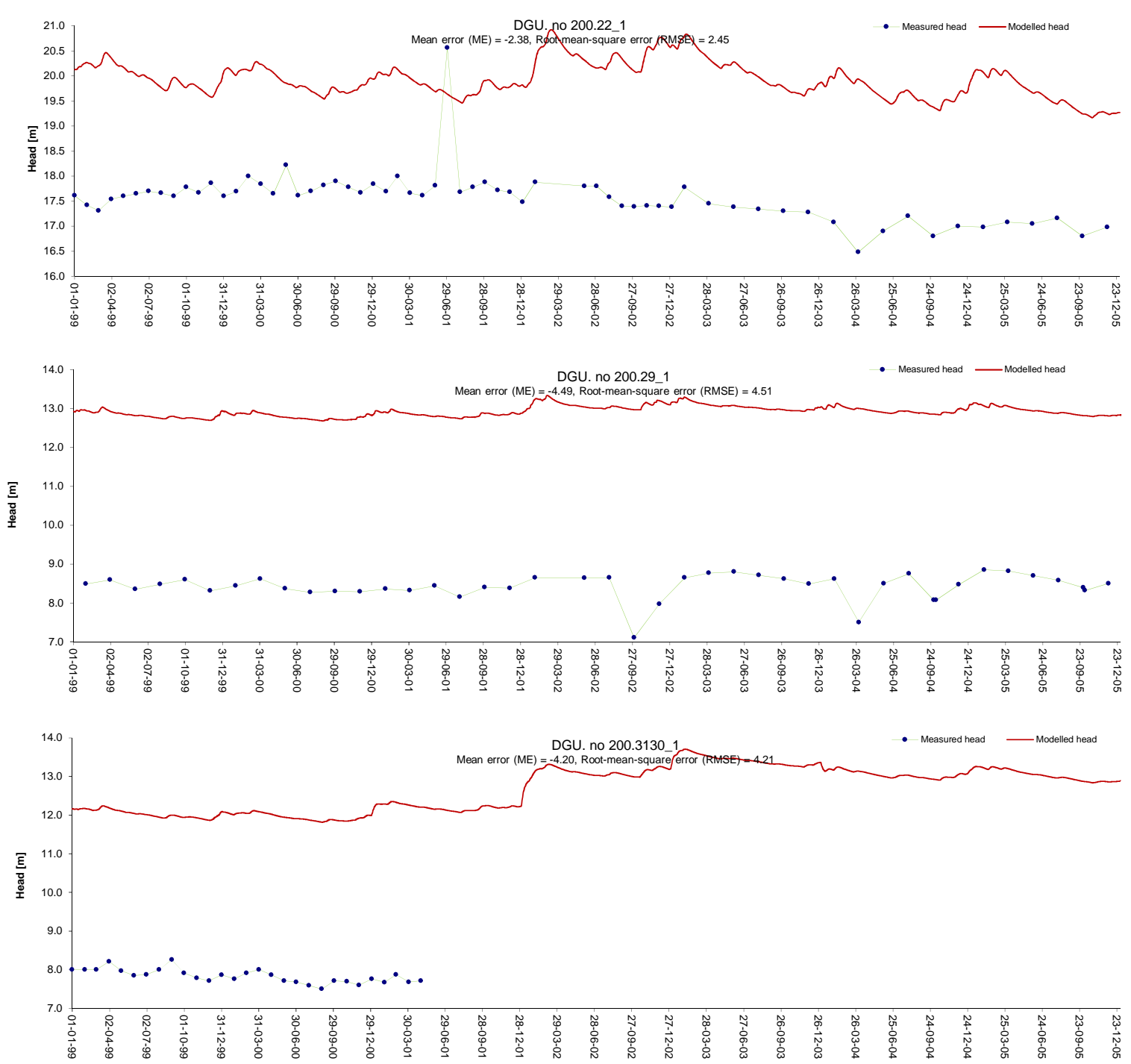

DGU. no 200.3166_1
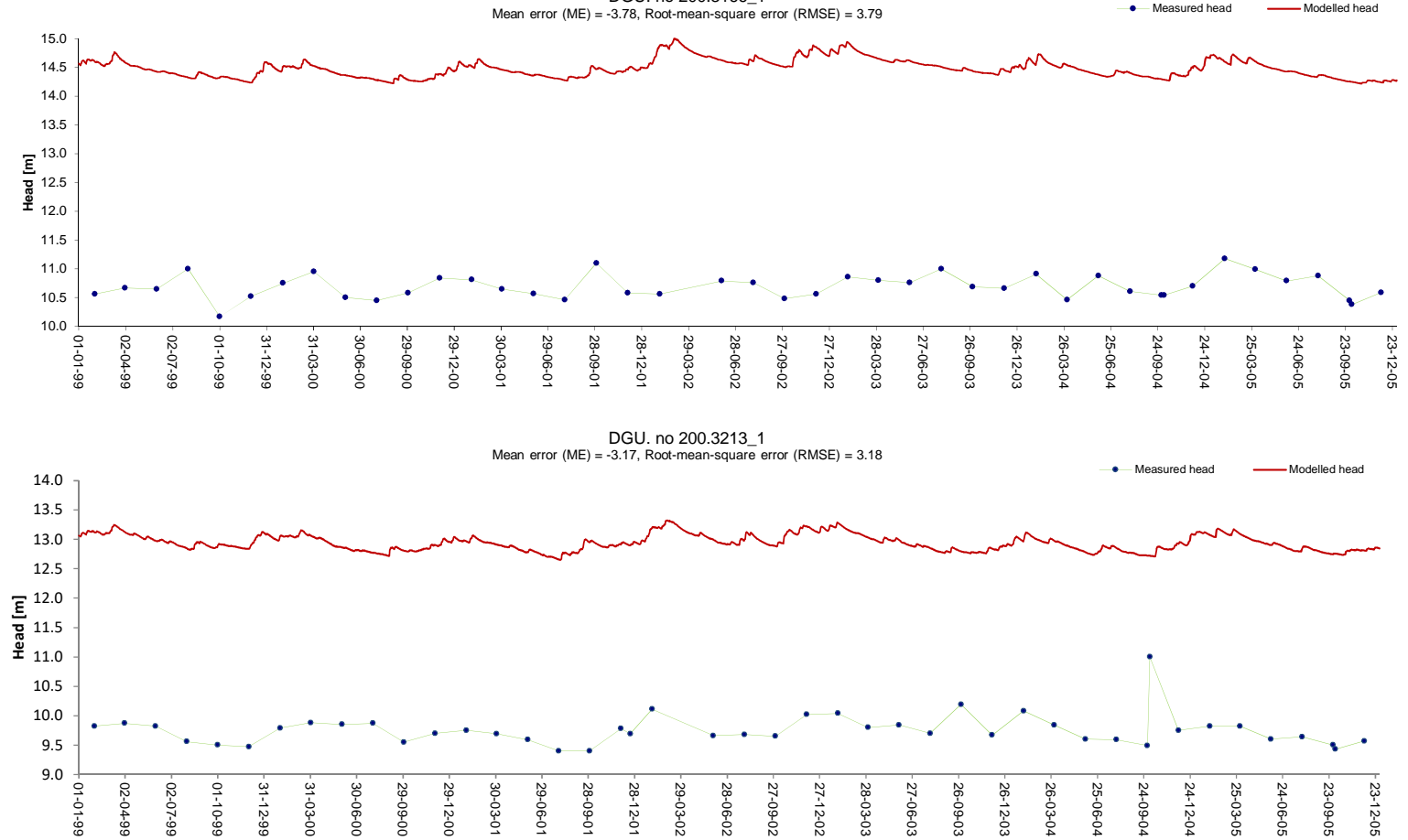

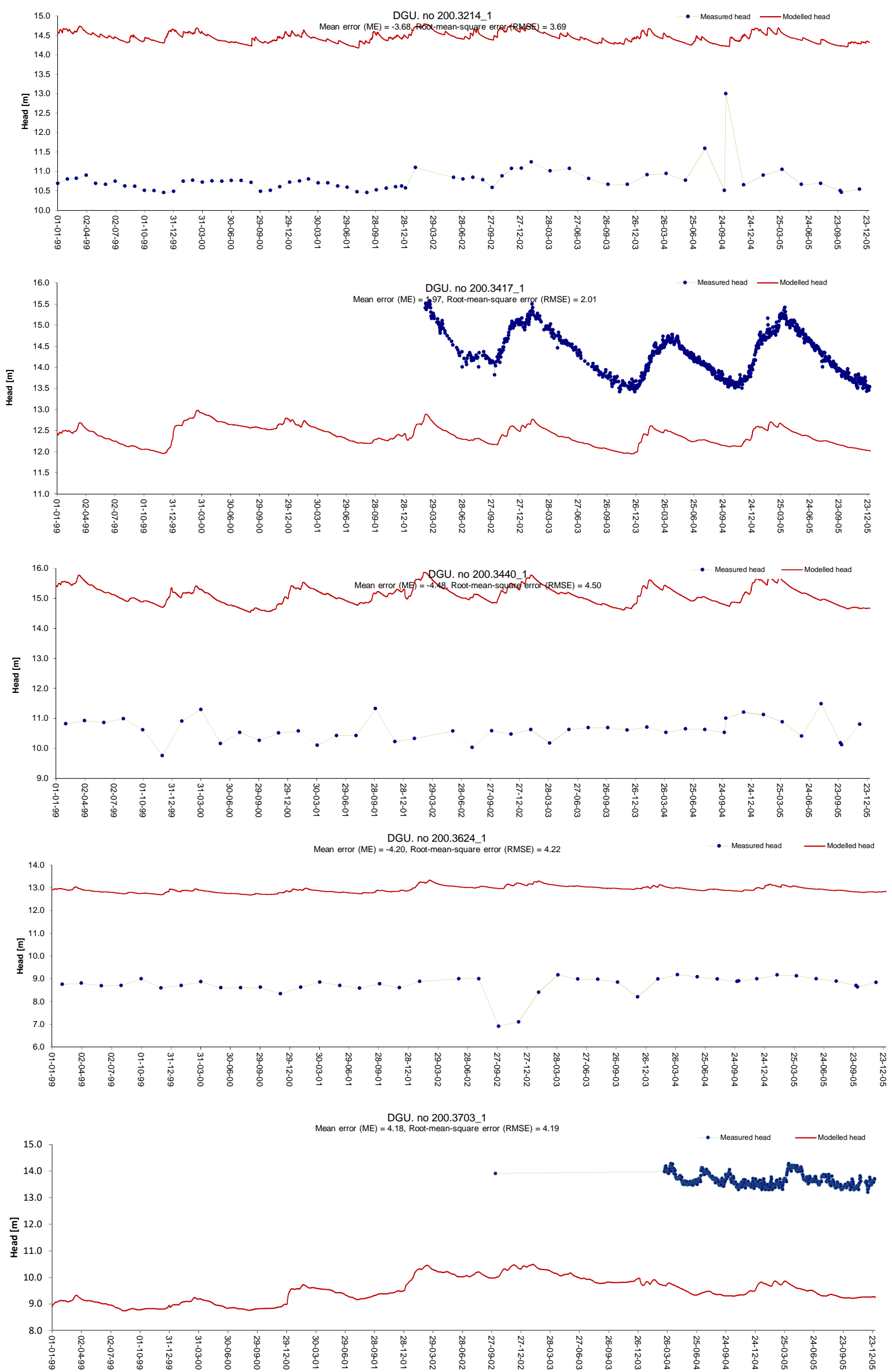

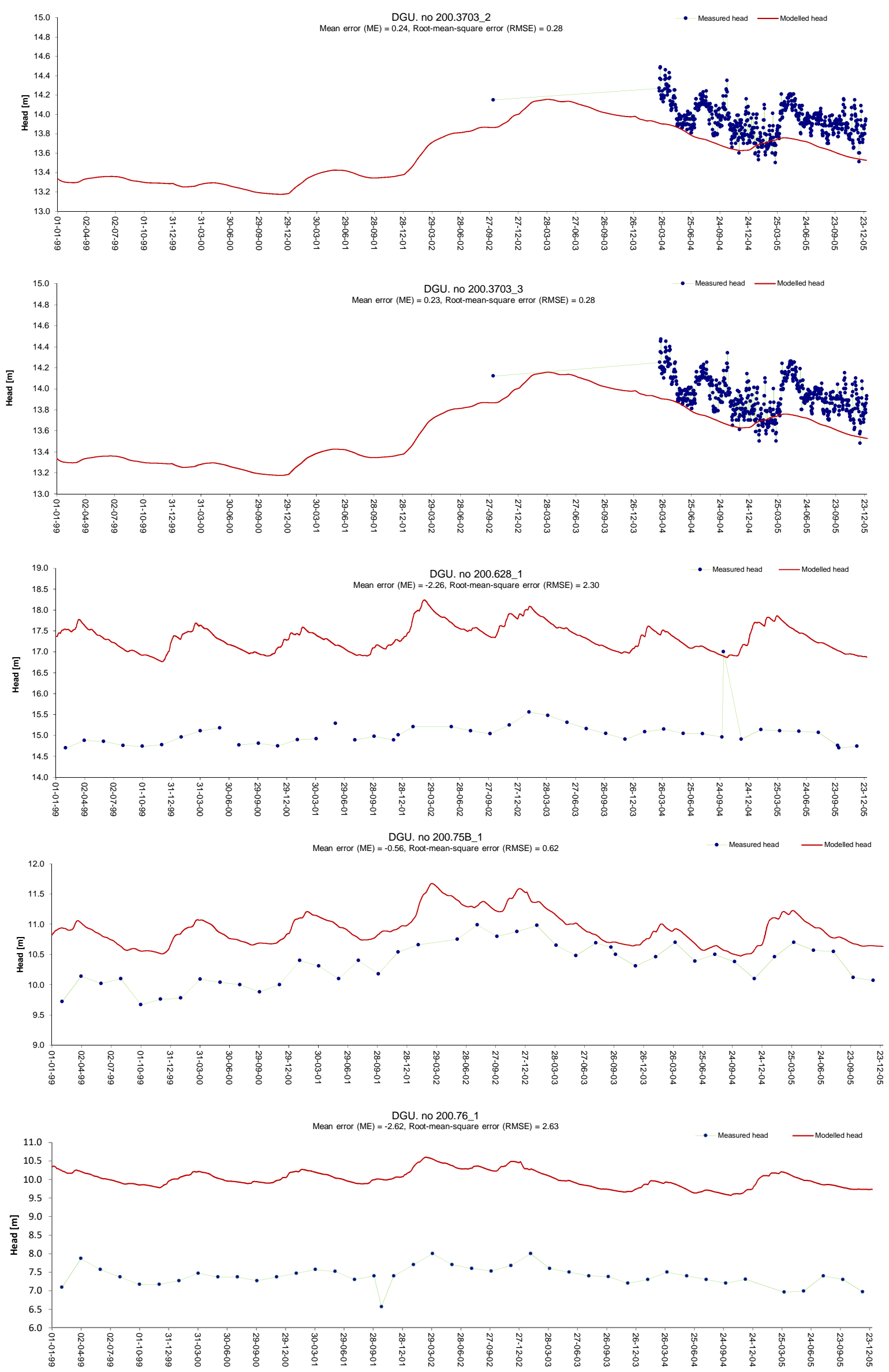

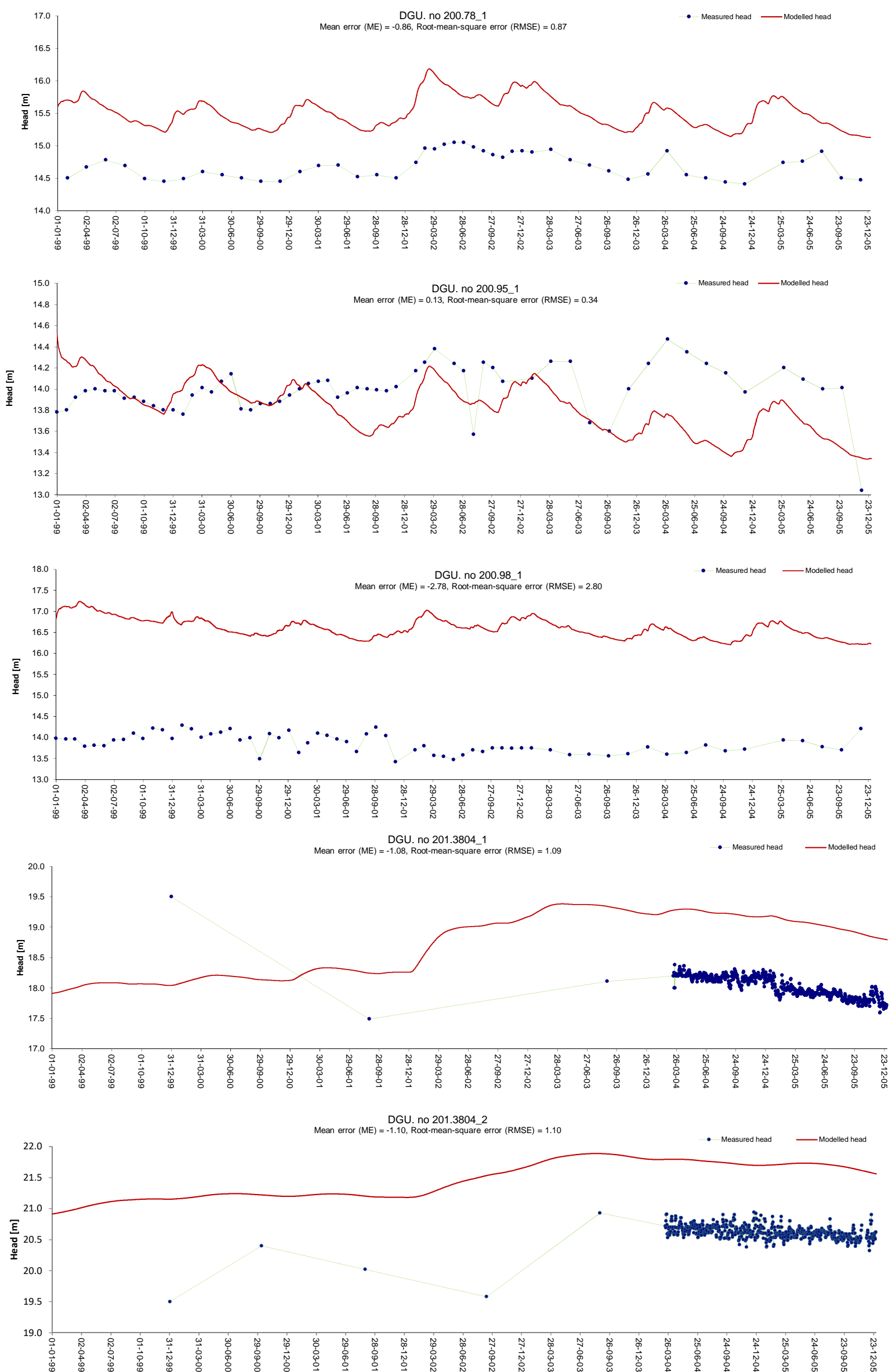

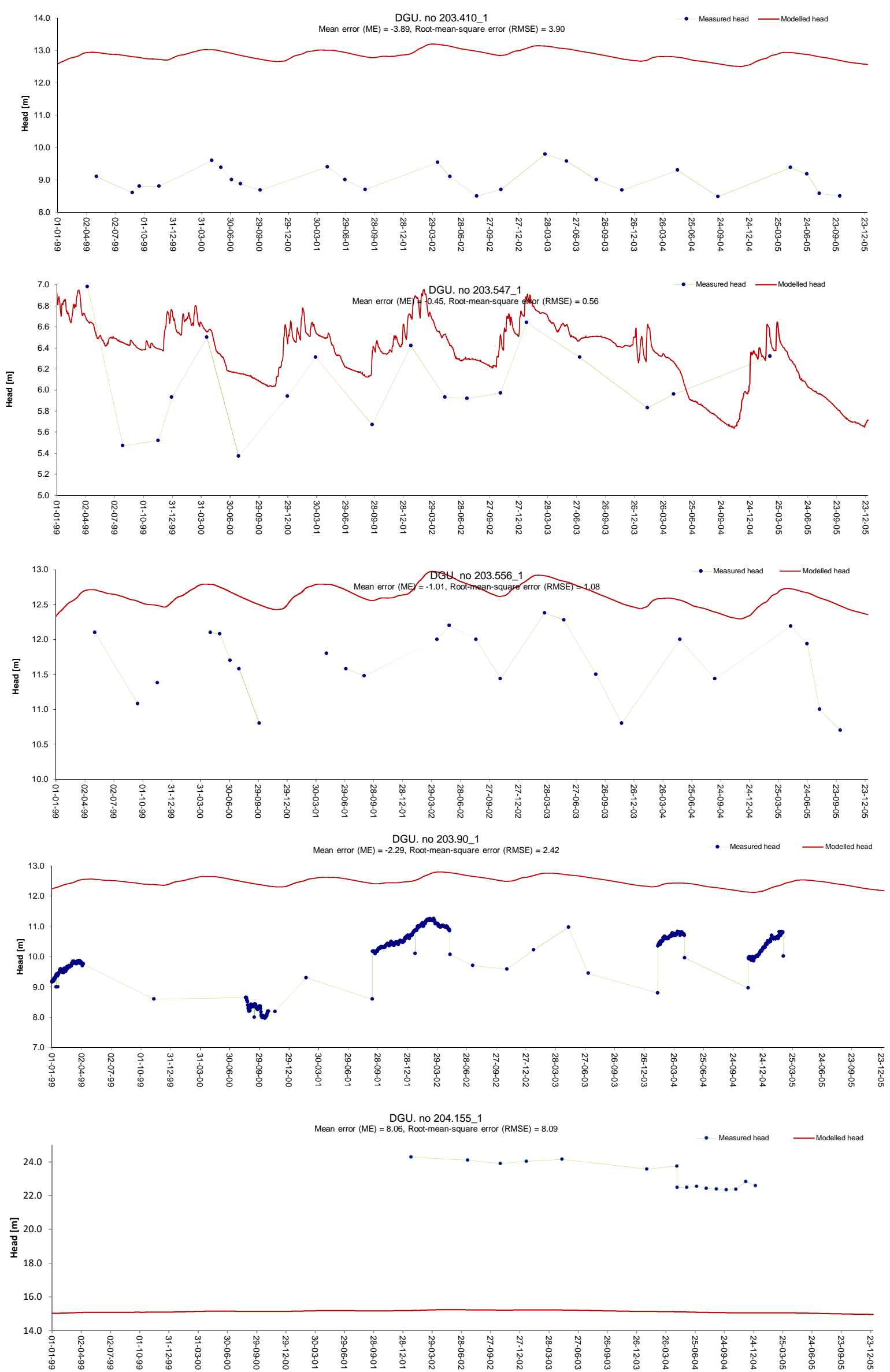

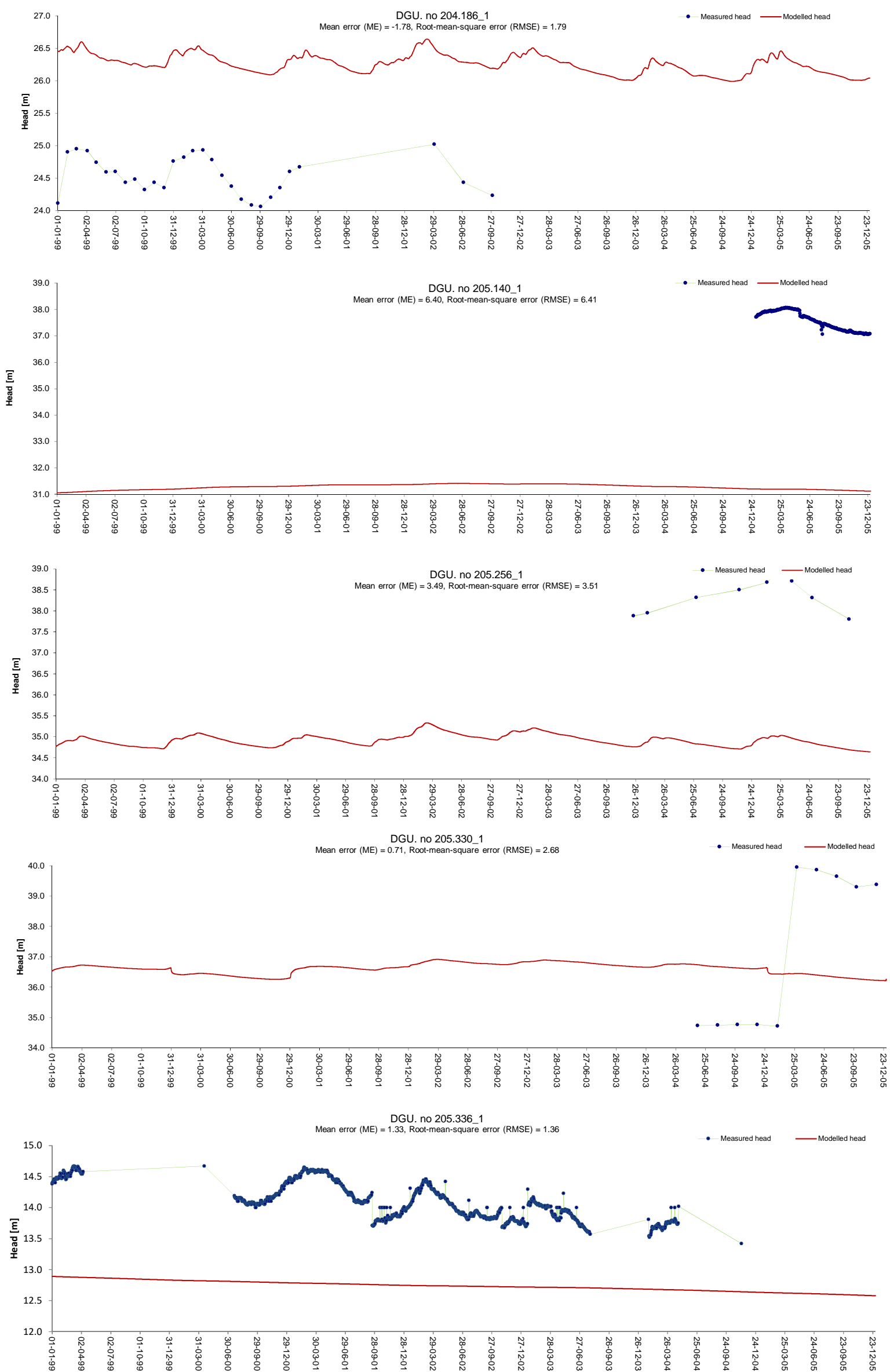

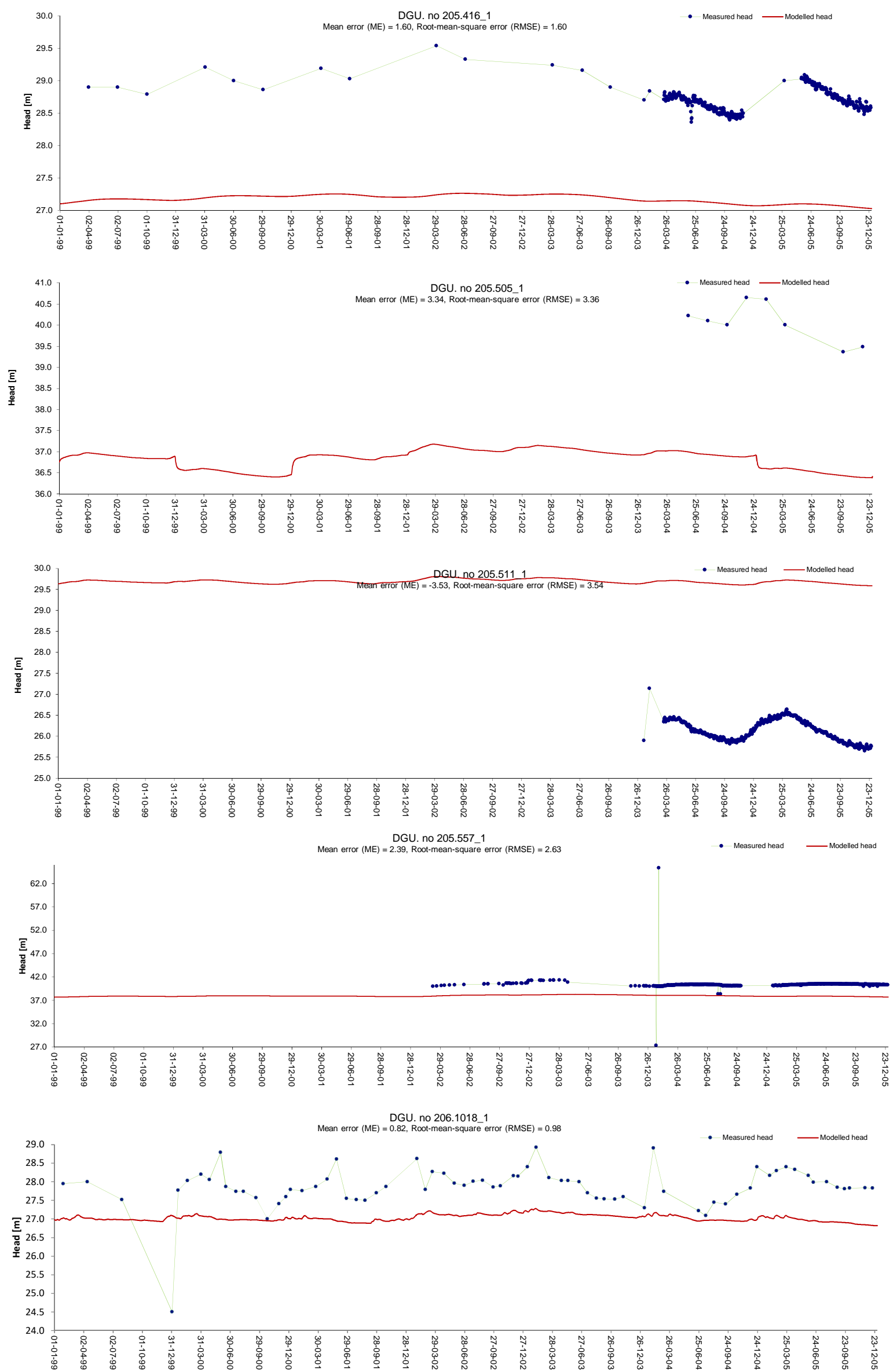

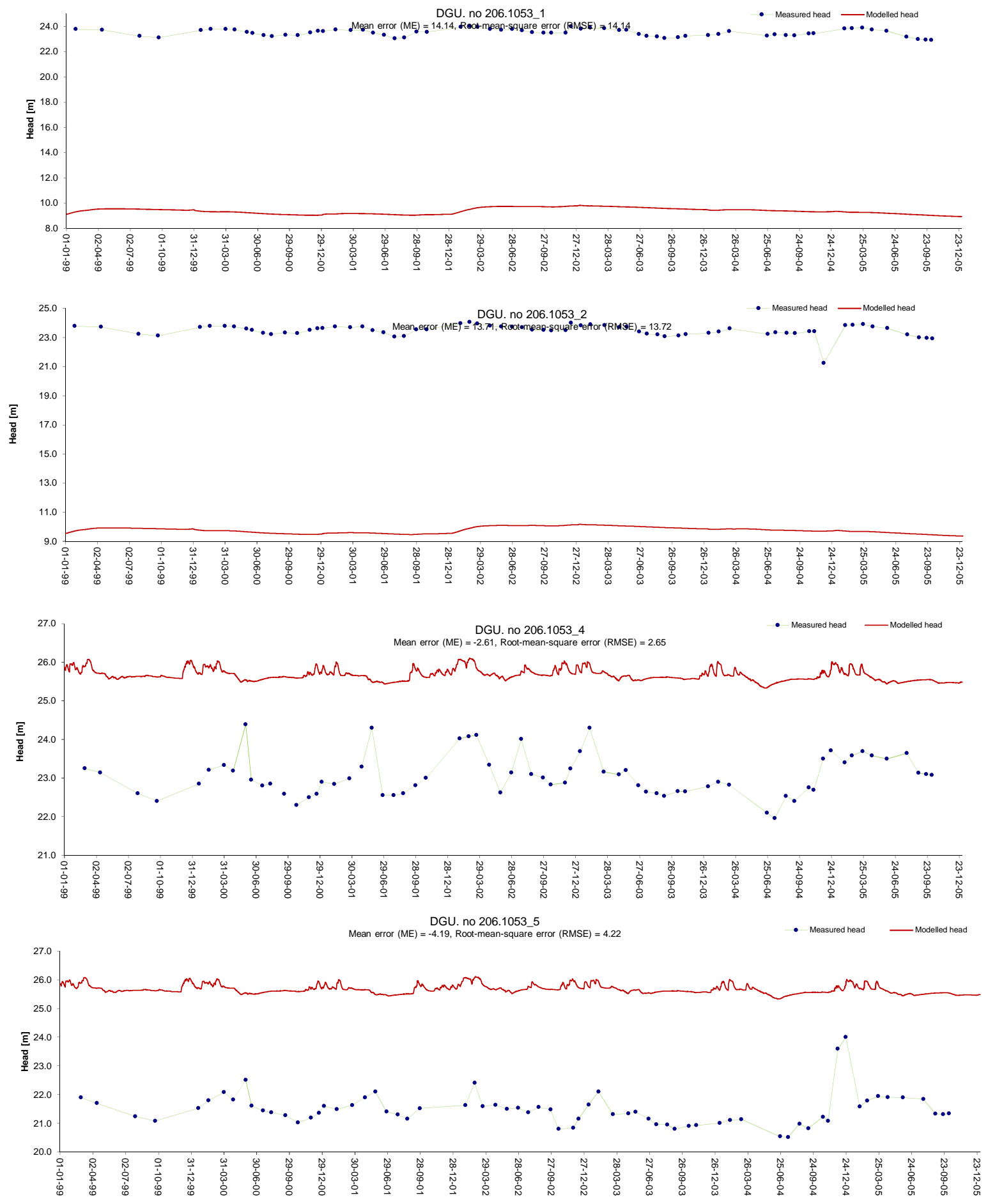

DGU. no 206.105_1

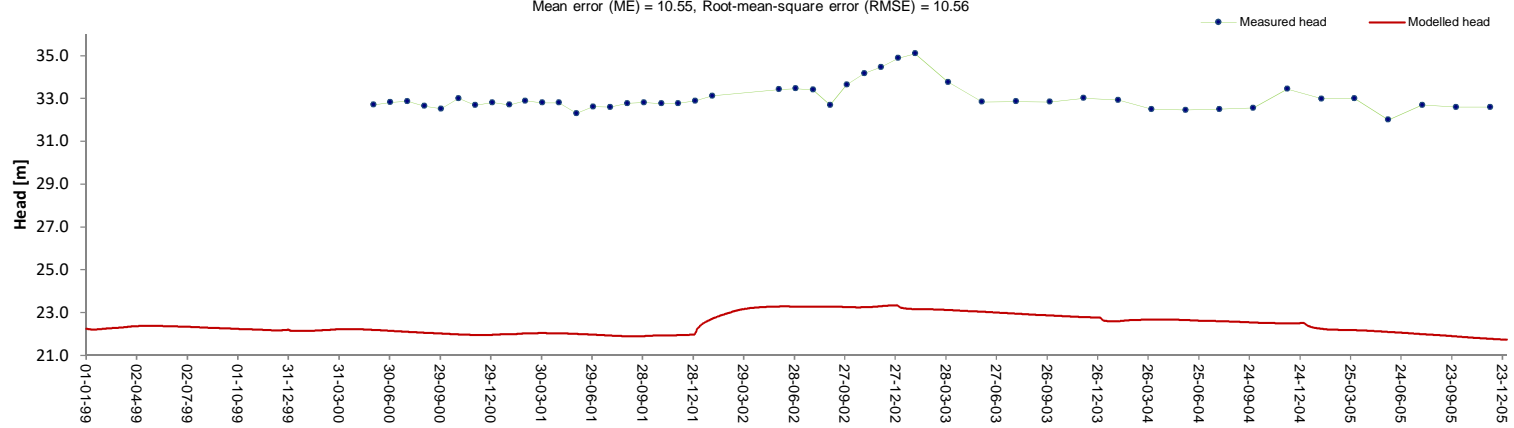



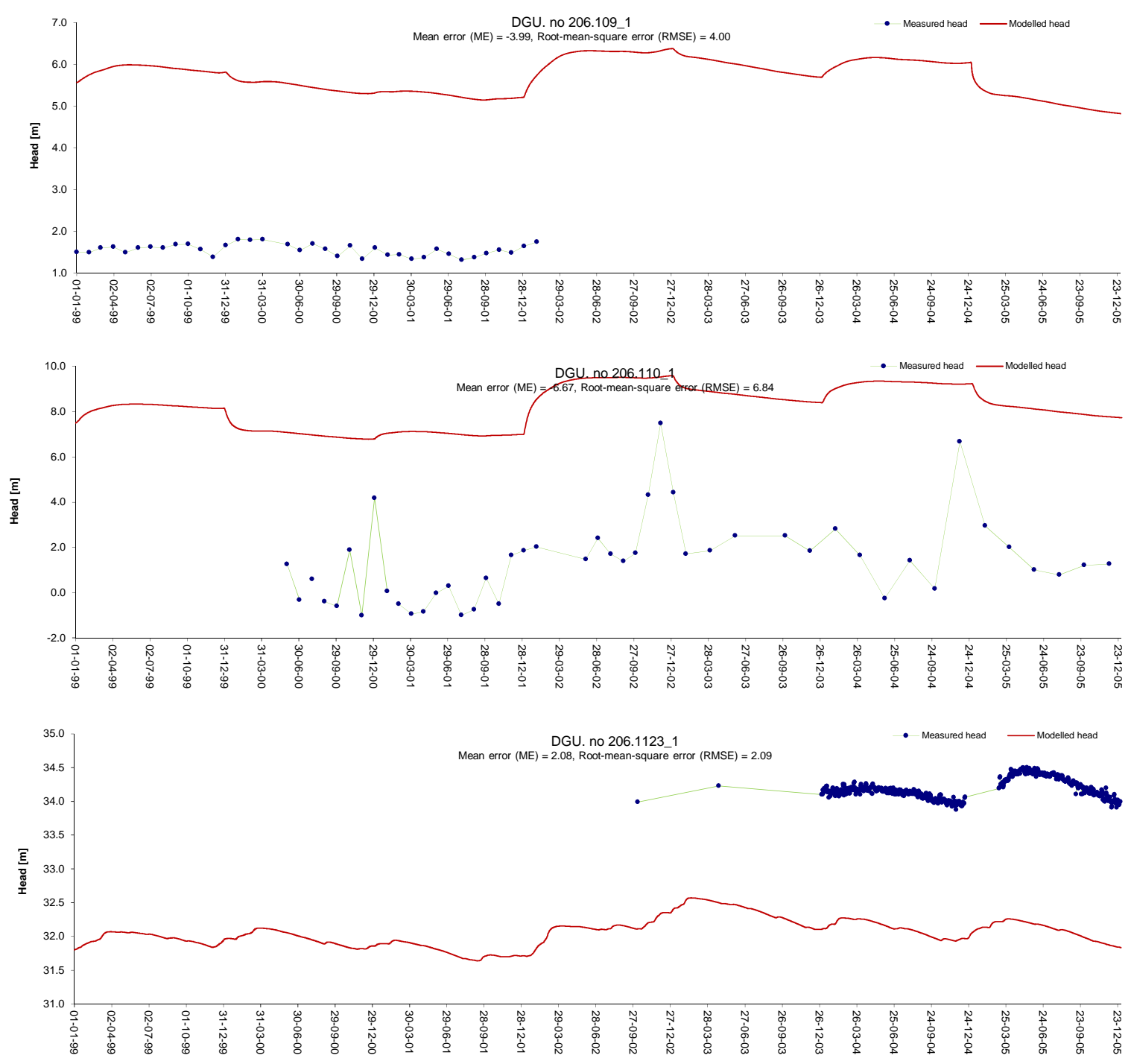

Mean error (ME) $=-13.48$, noot-mean-square 2
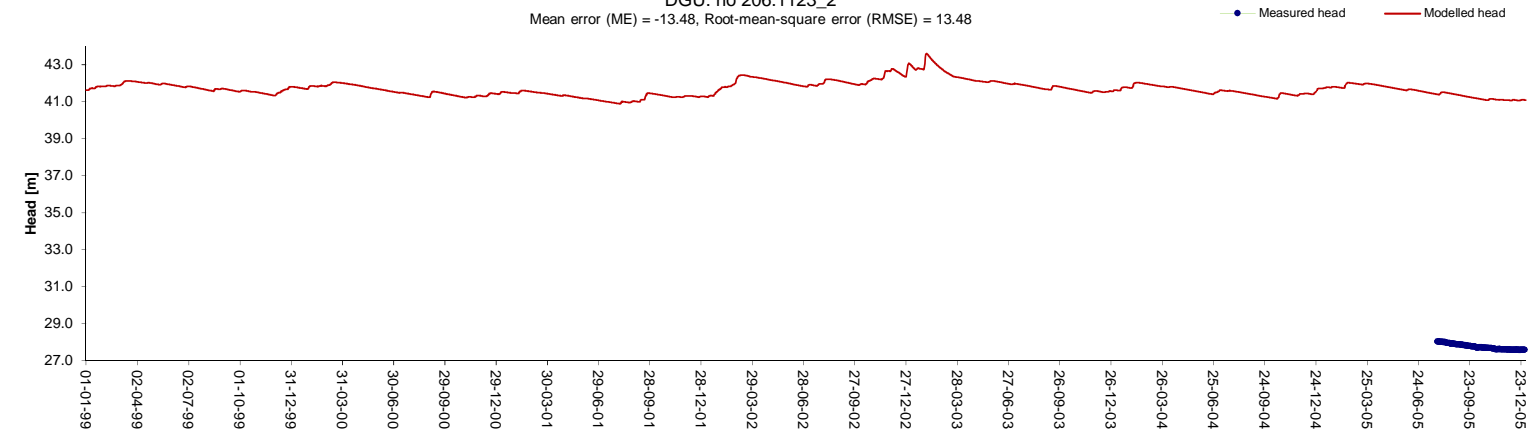

DGU. no 206.1237_1

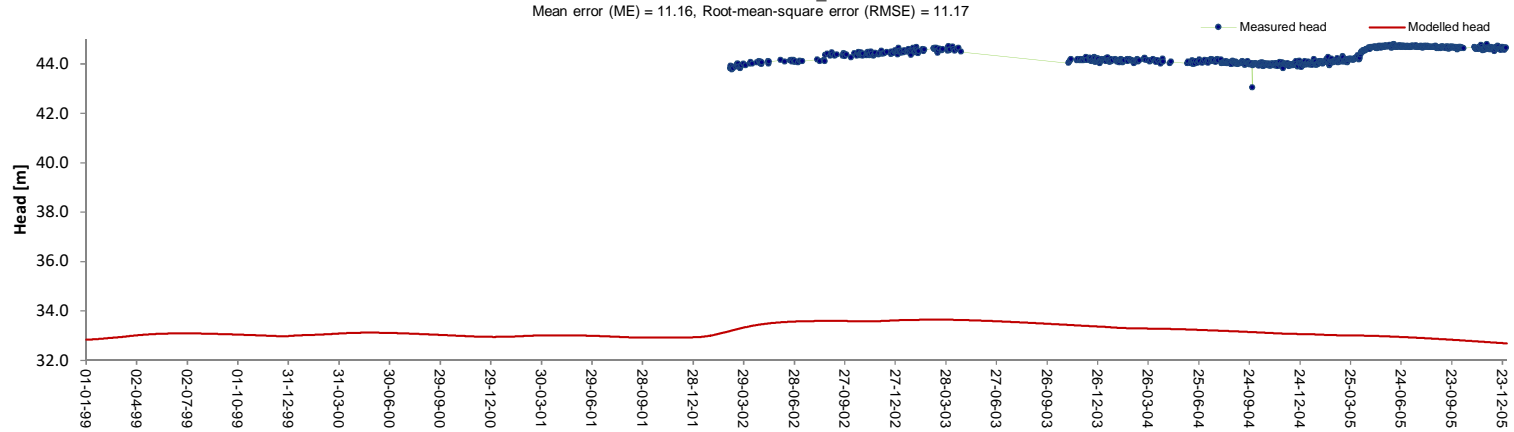



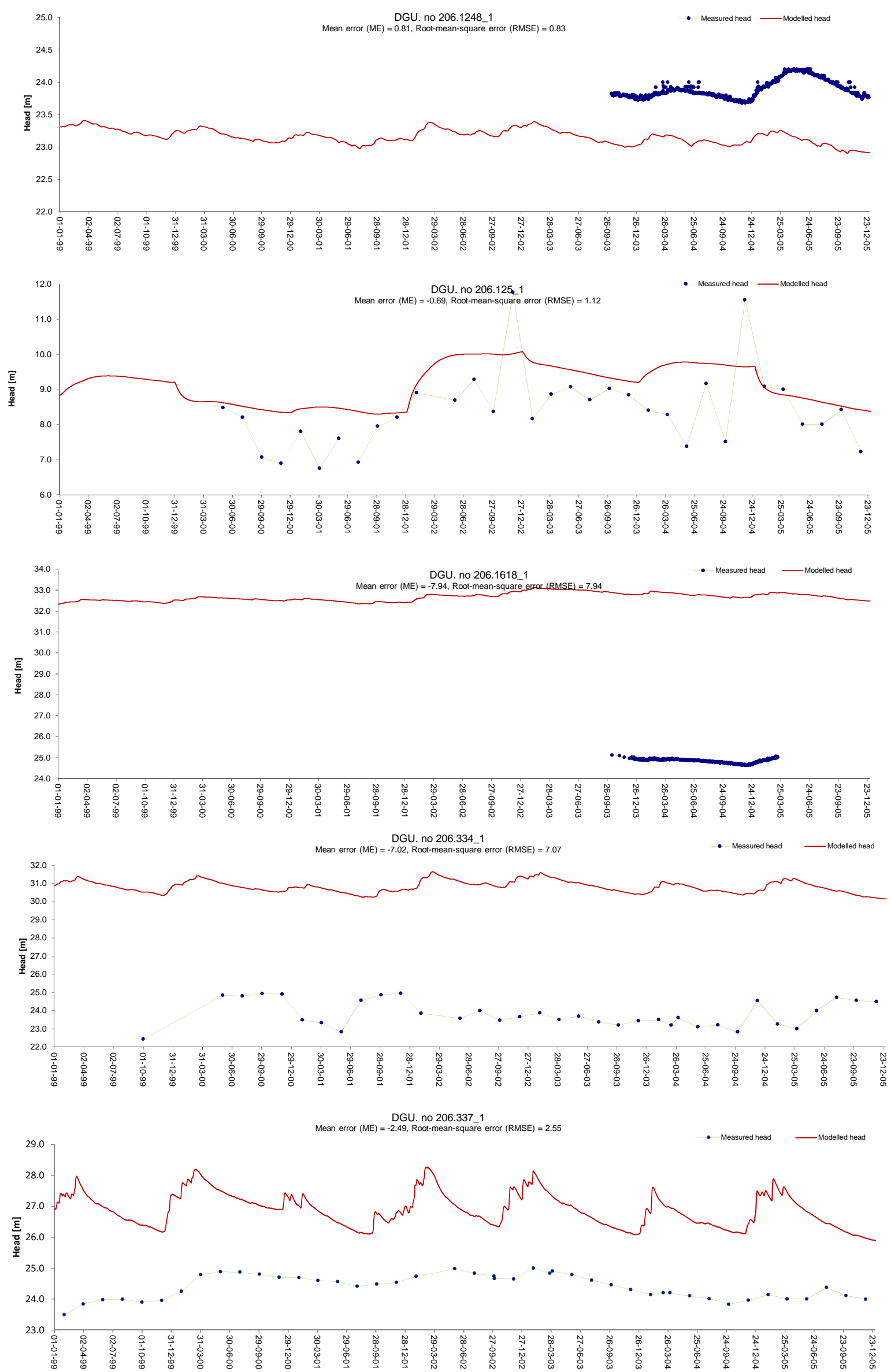

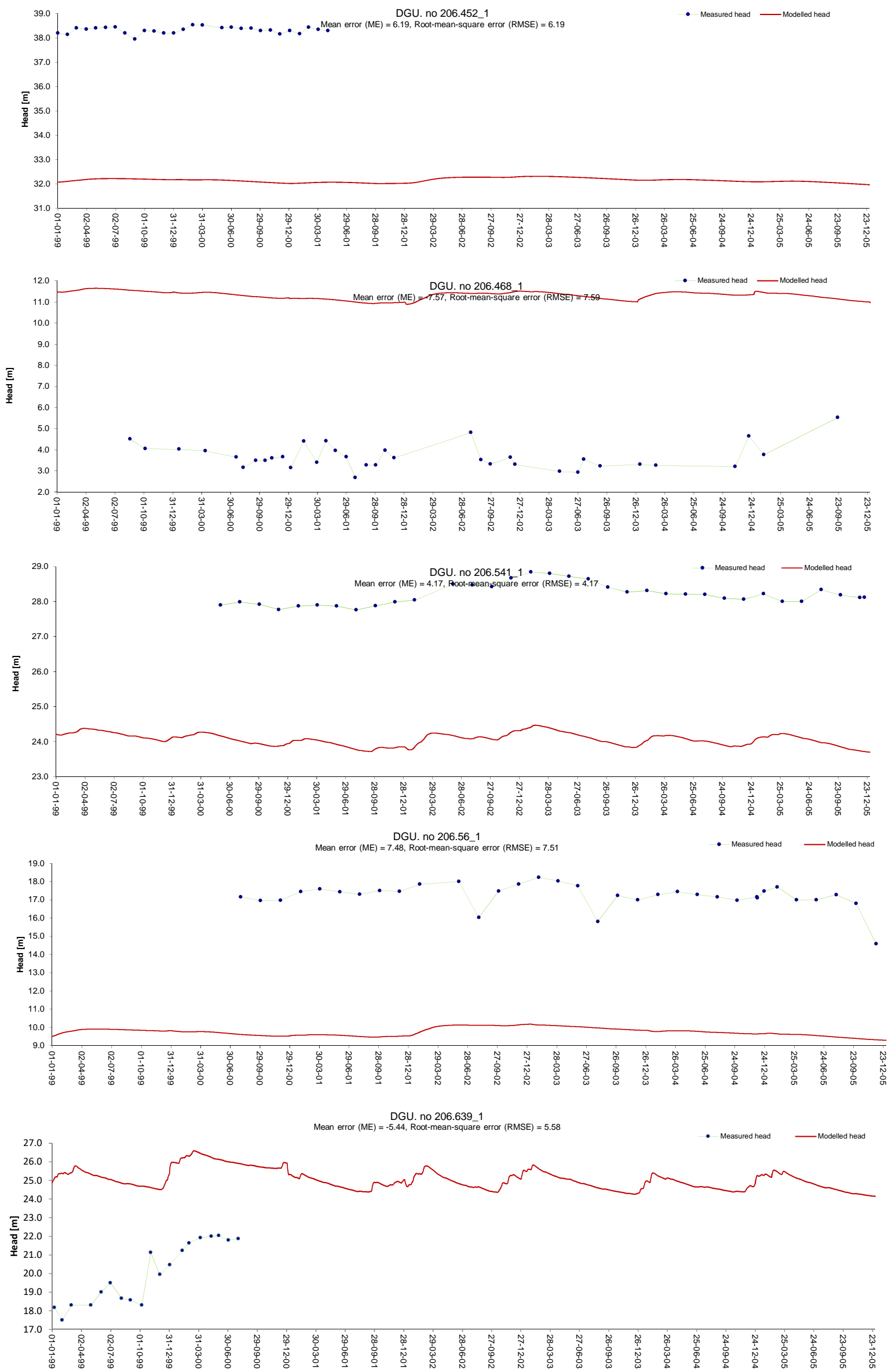

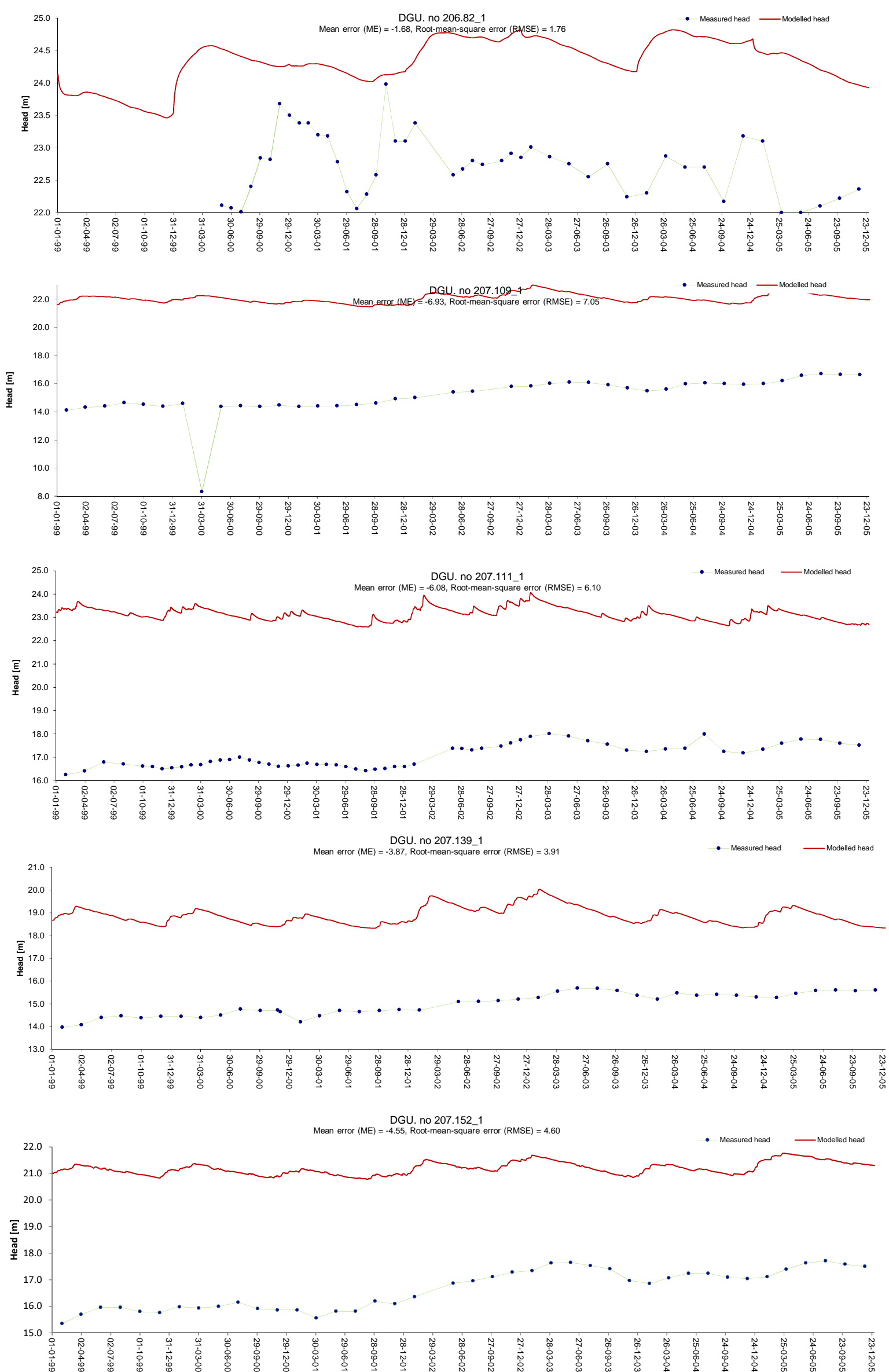

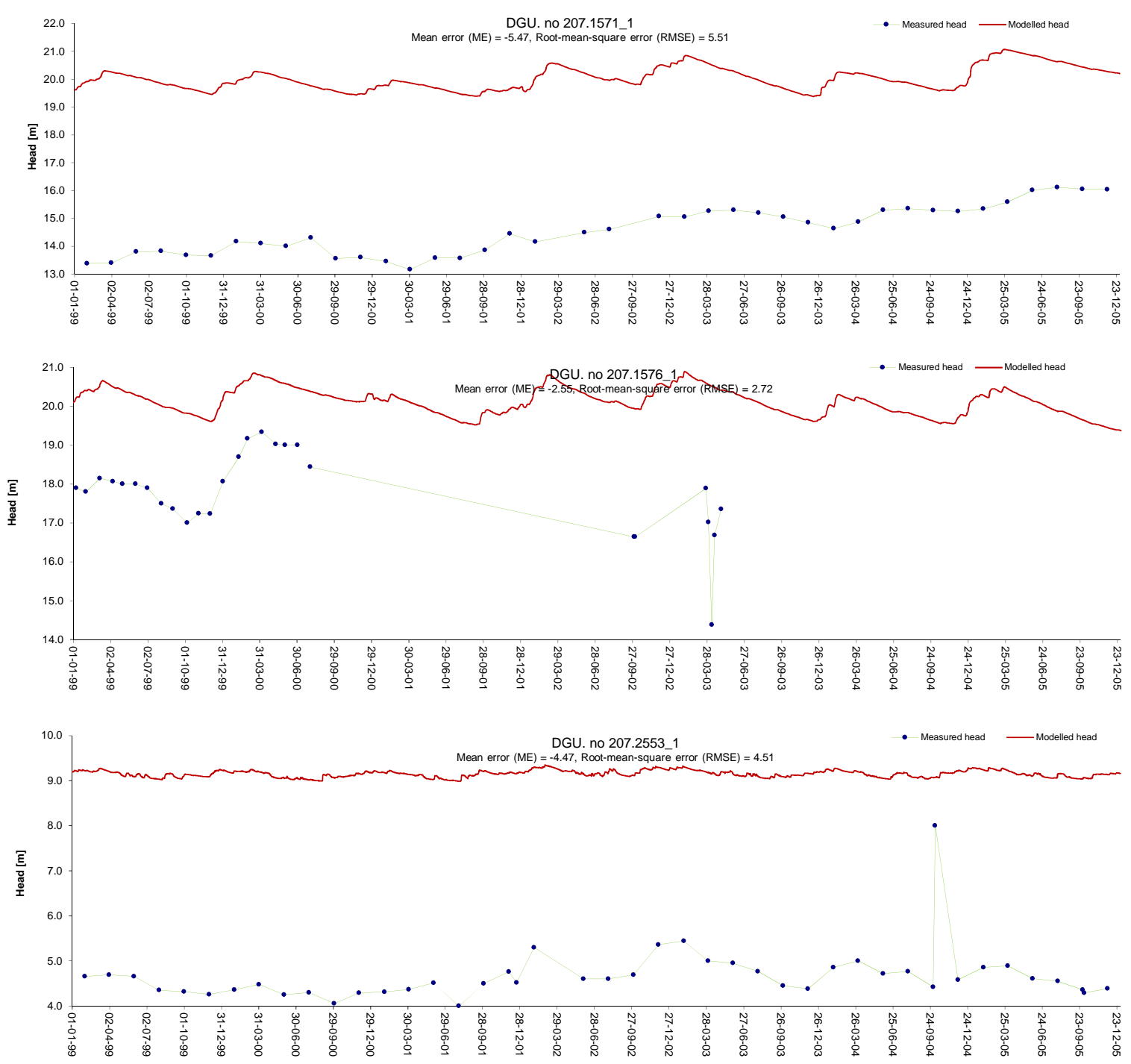

DGU. no 207.2554_1
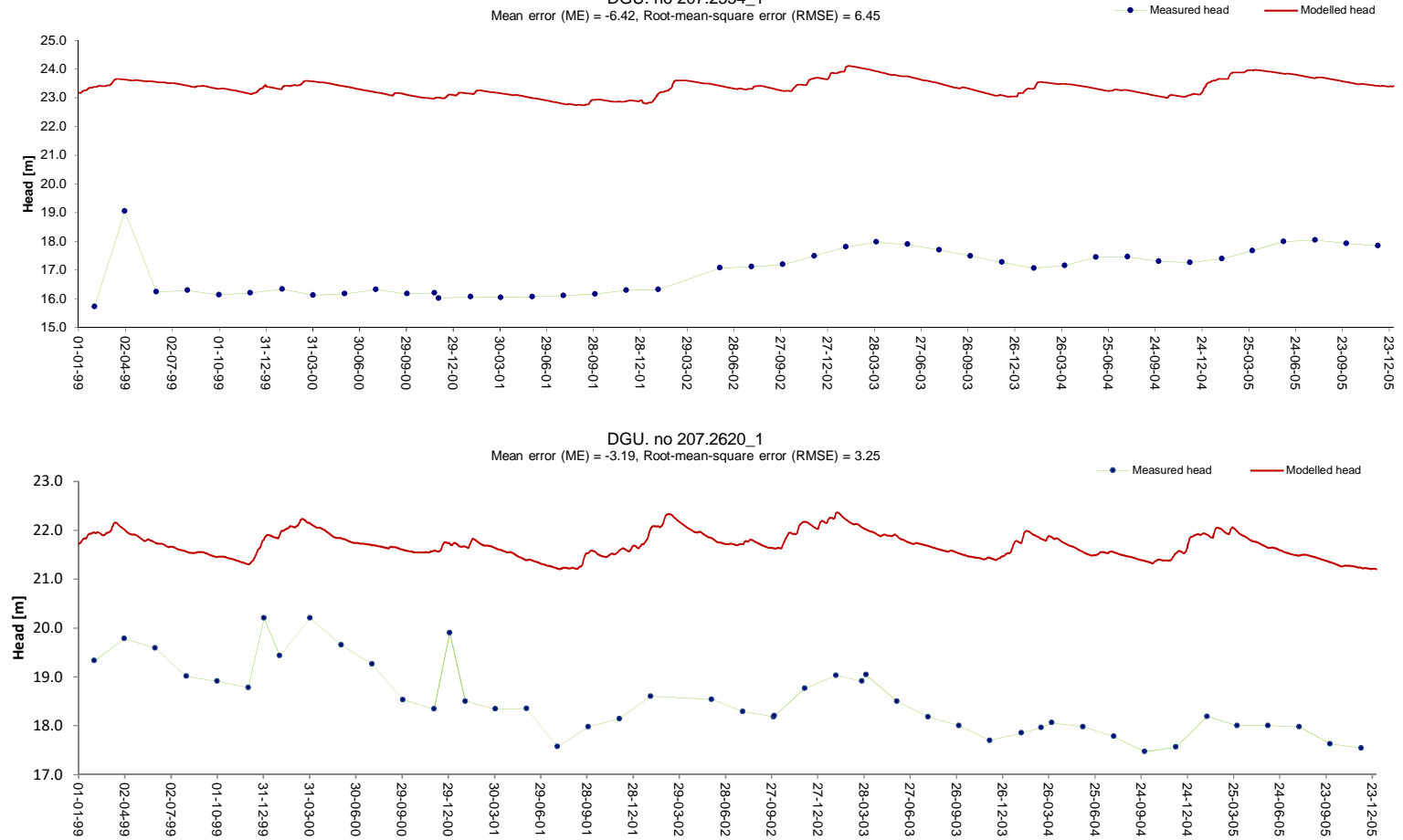

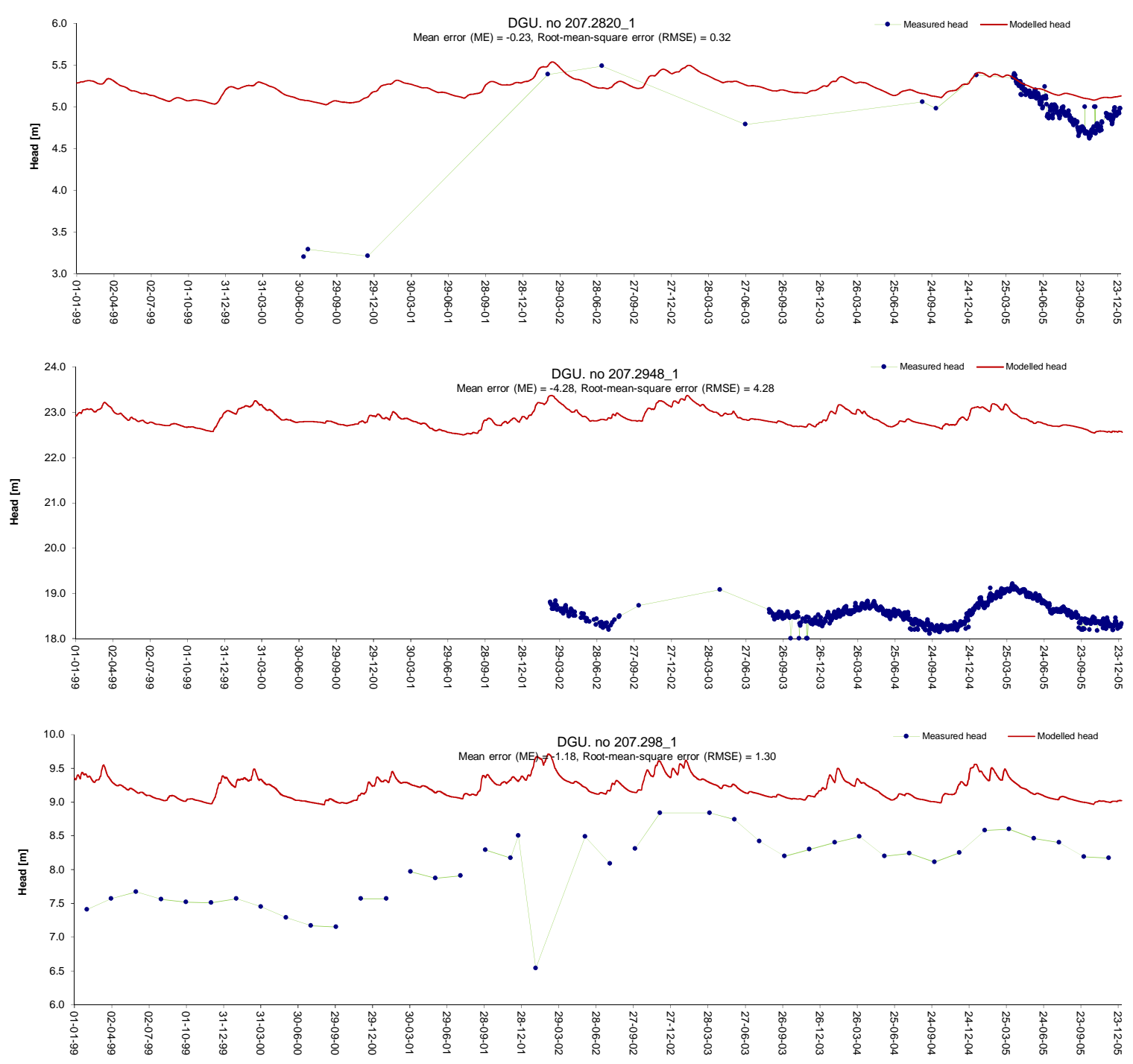
DGU. no 207.300_1
Mean error $(\mathrm{ME})=-2.39$, Root-mean-square error (RMSE) $=2.52$
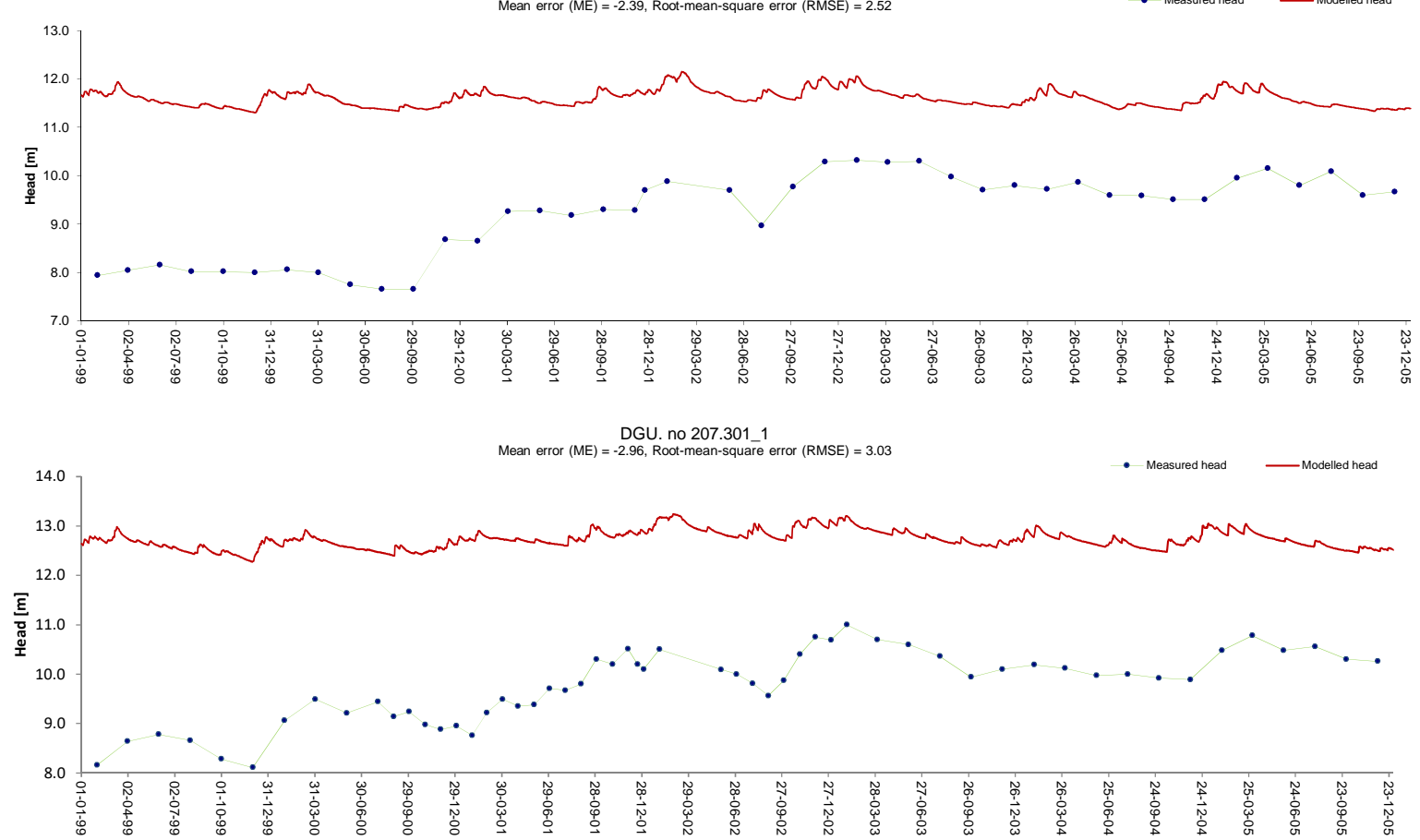

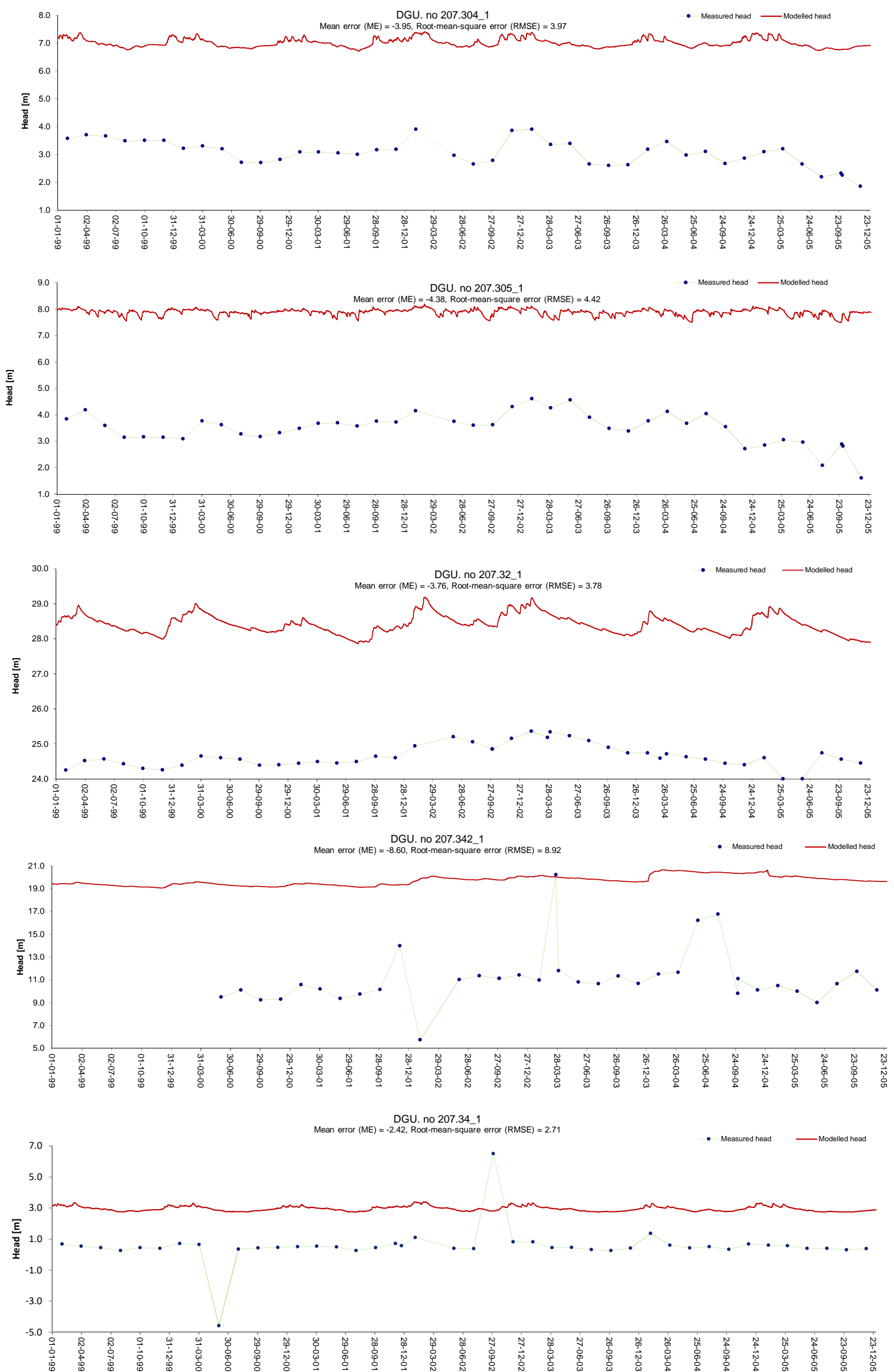

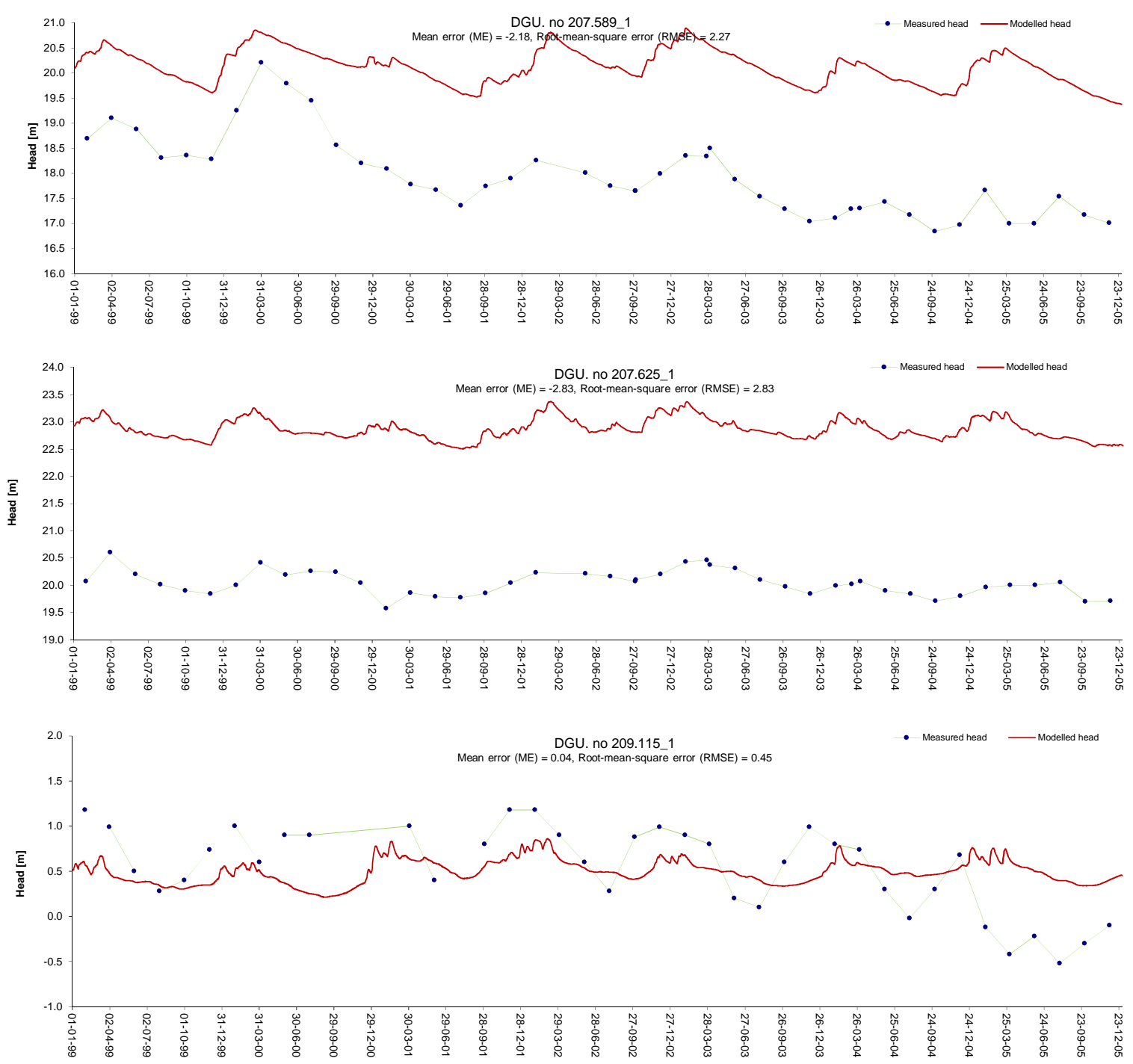

Mean error $(M E)=-393$. no 209.147
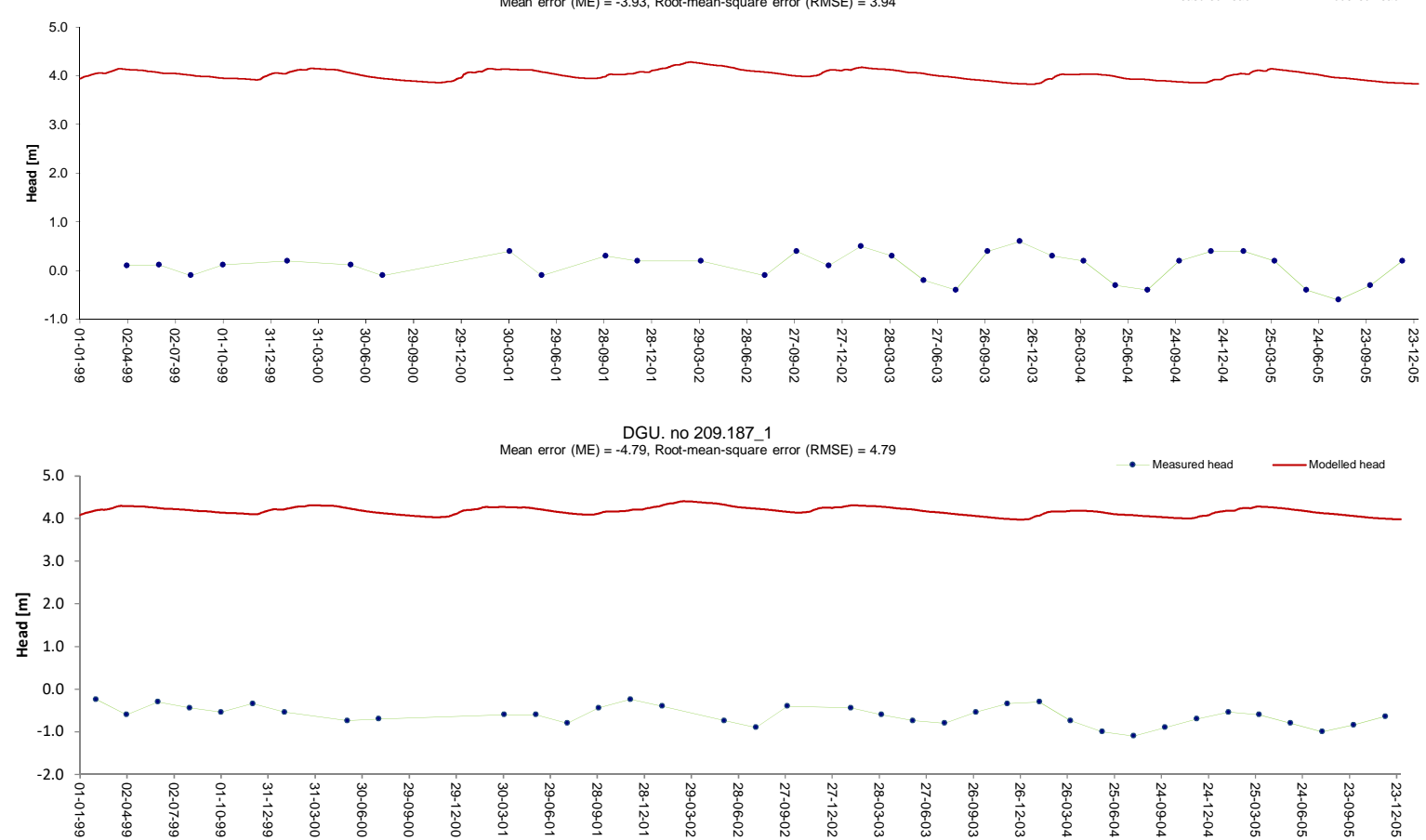

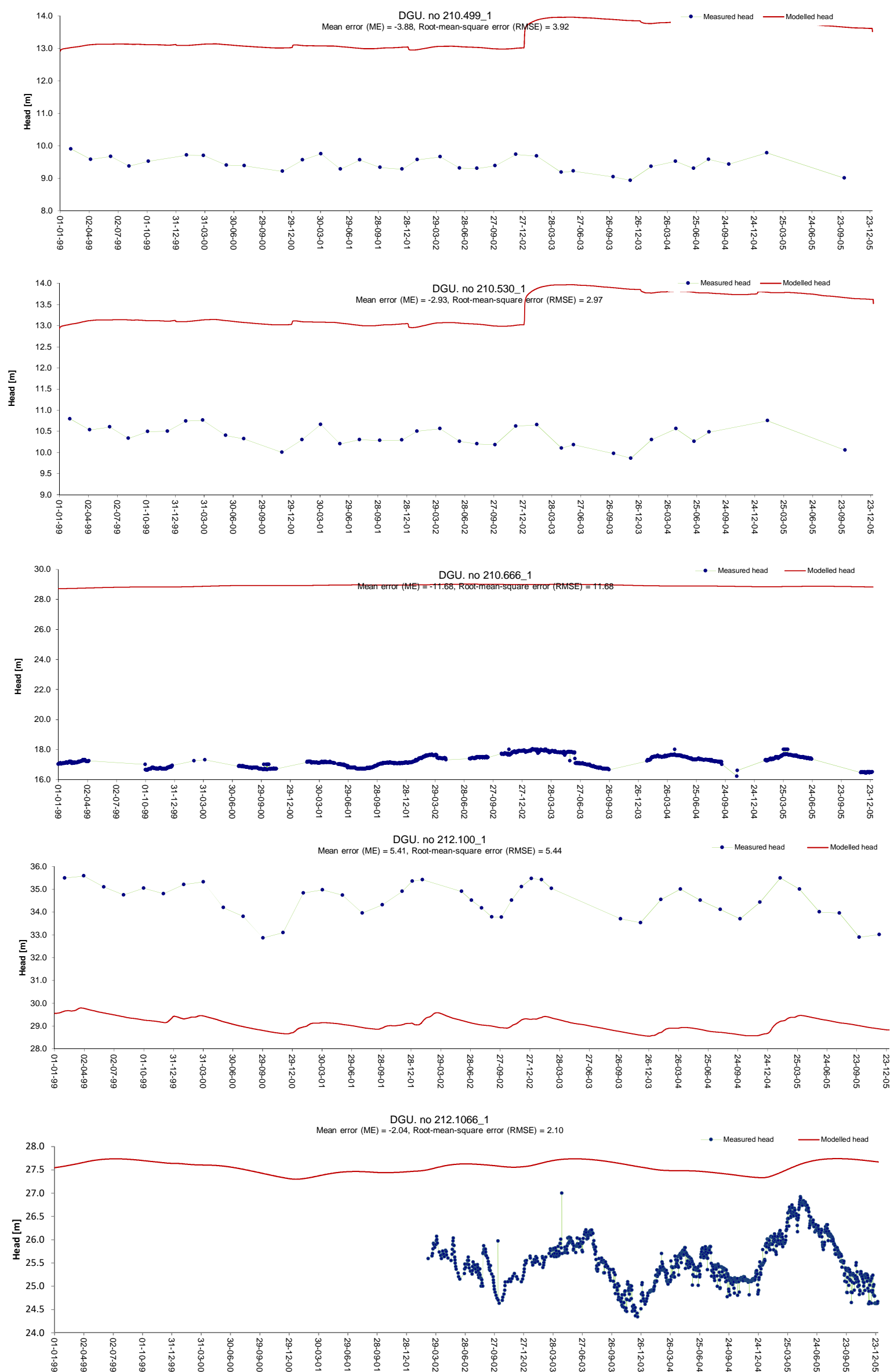

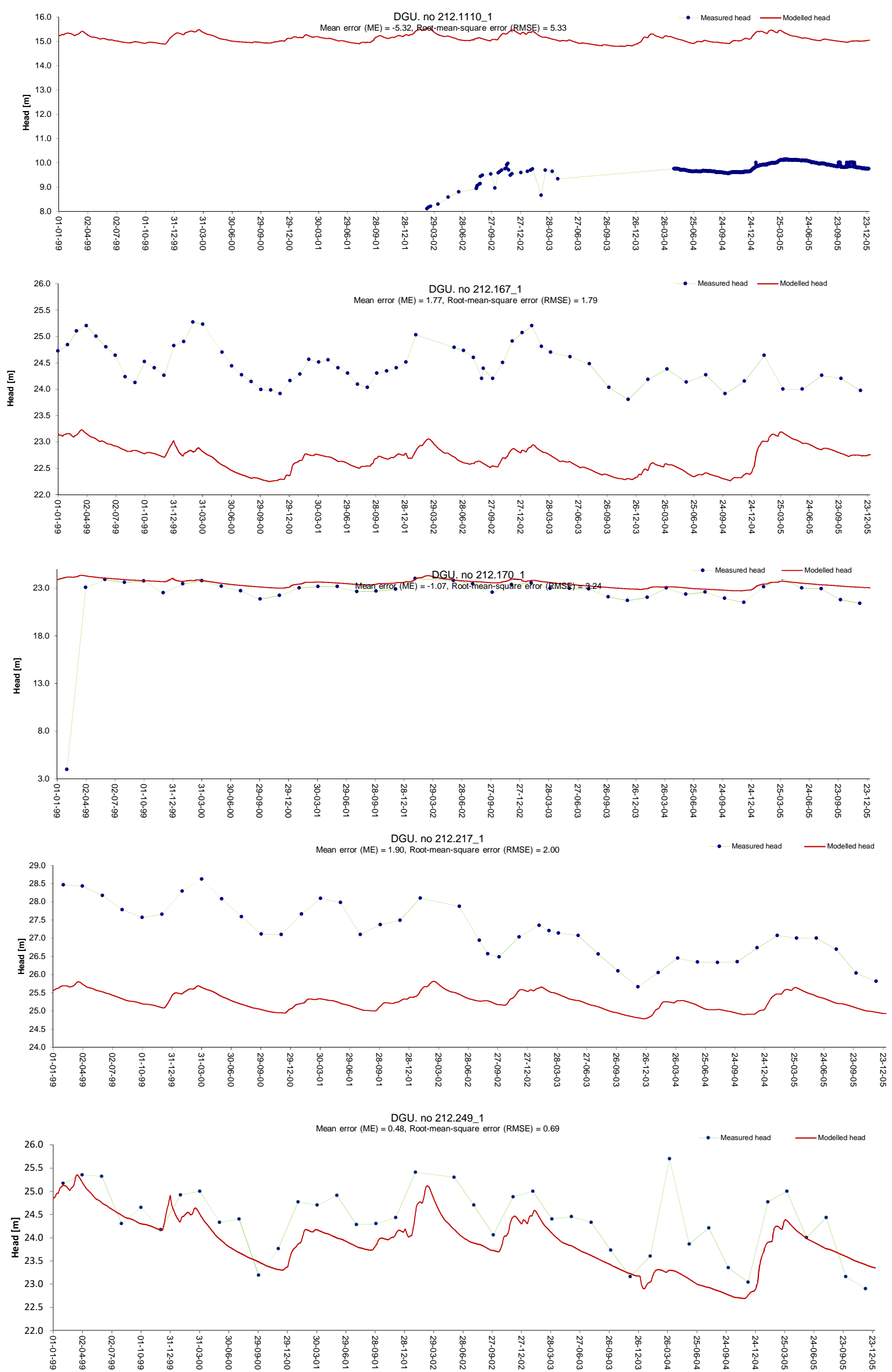

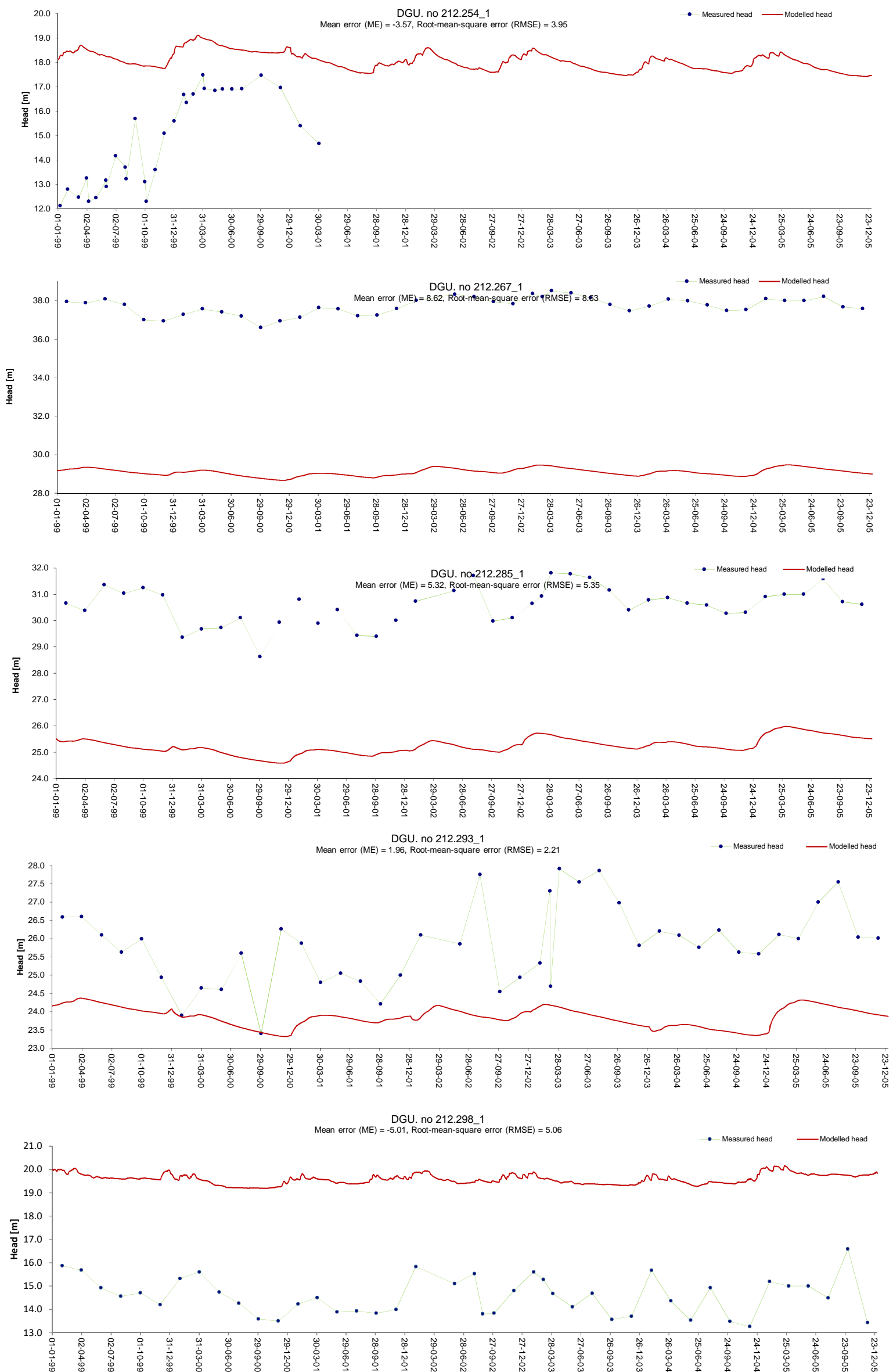

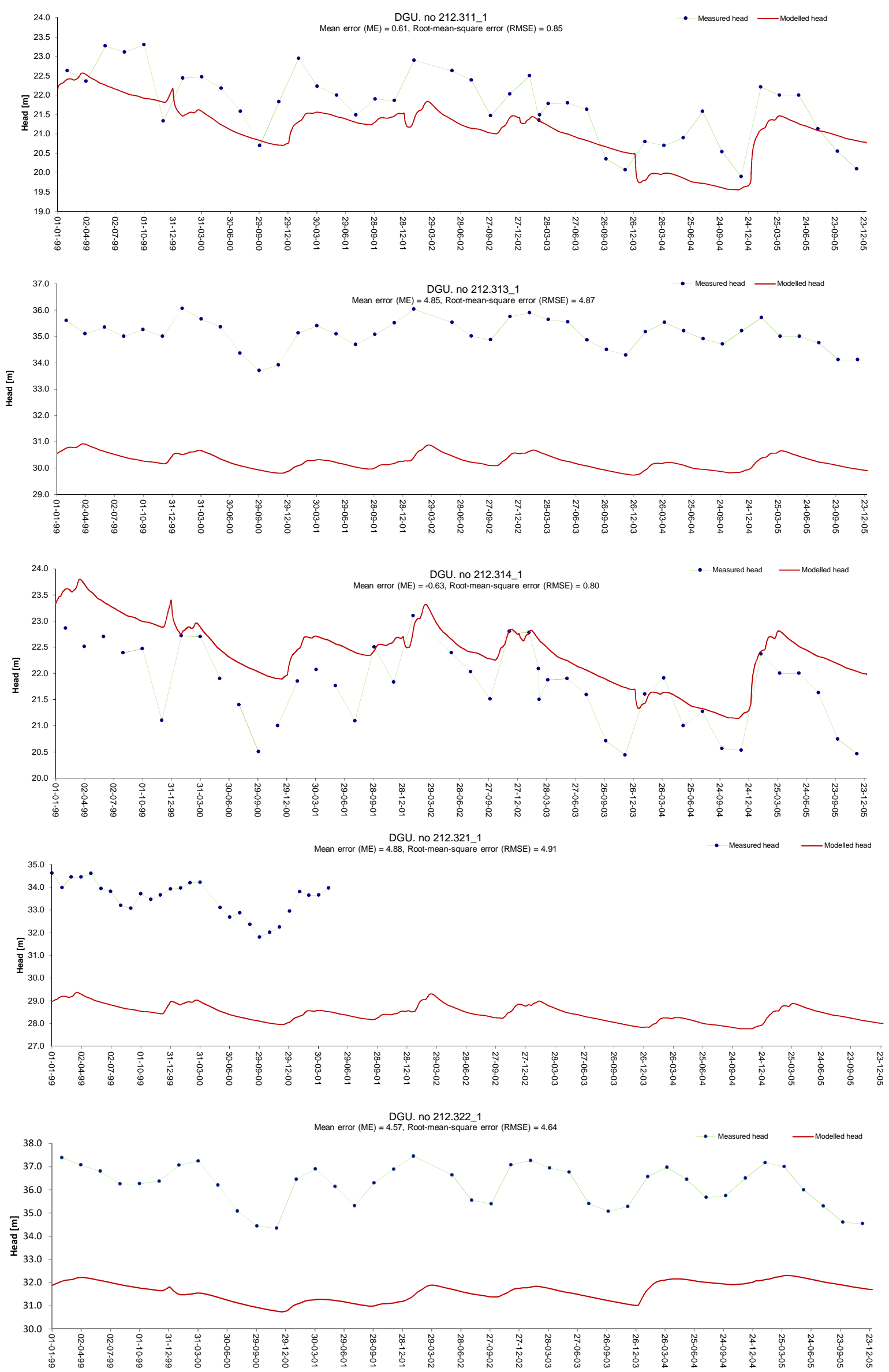

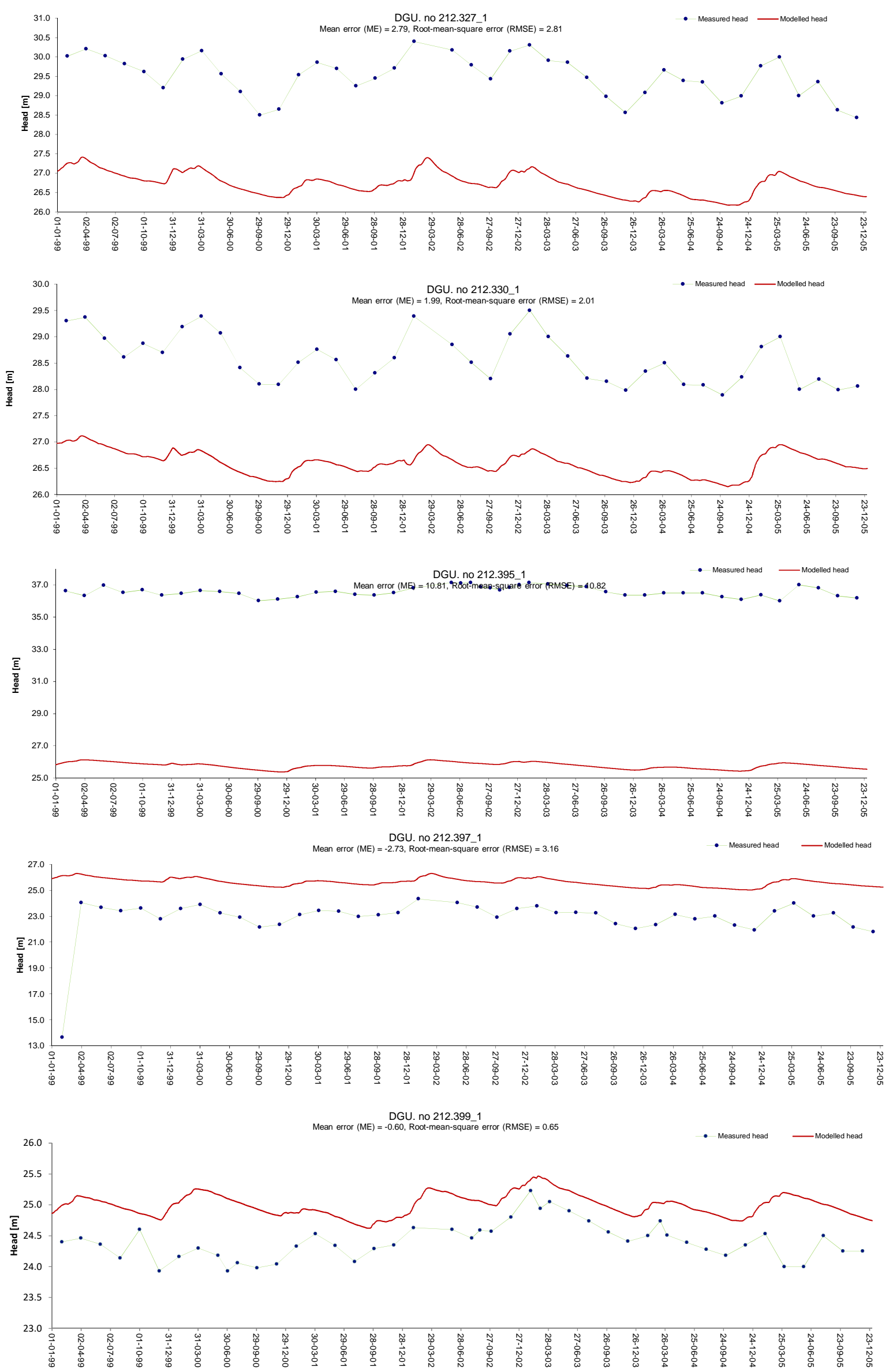

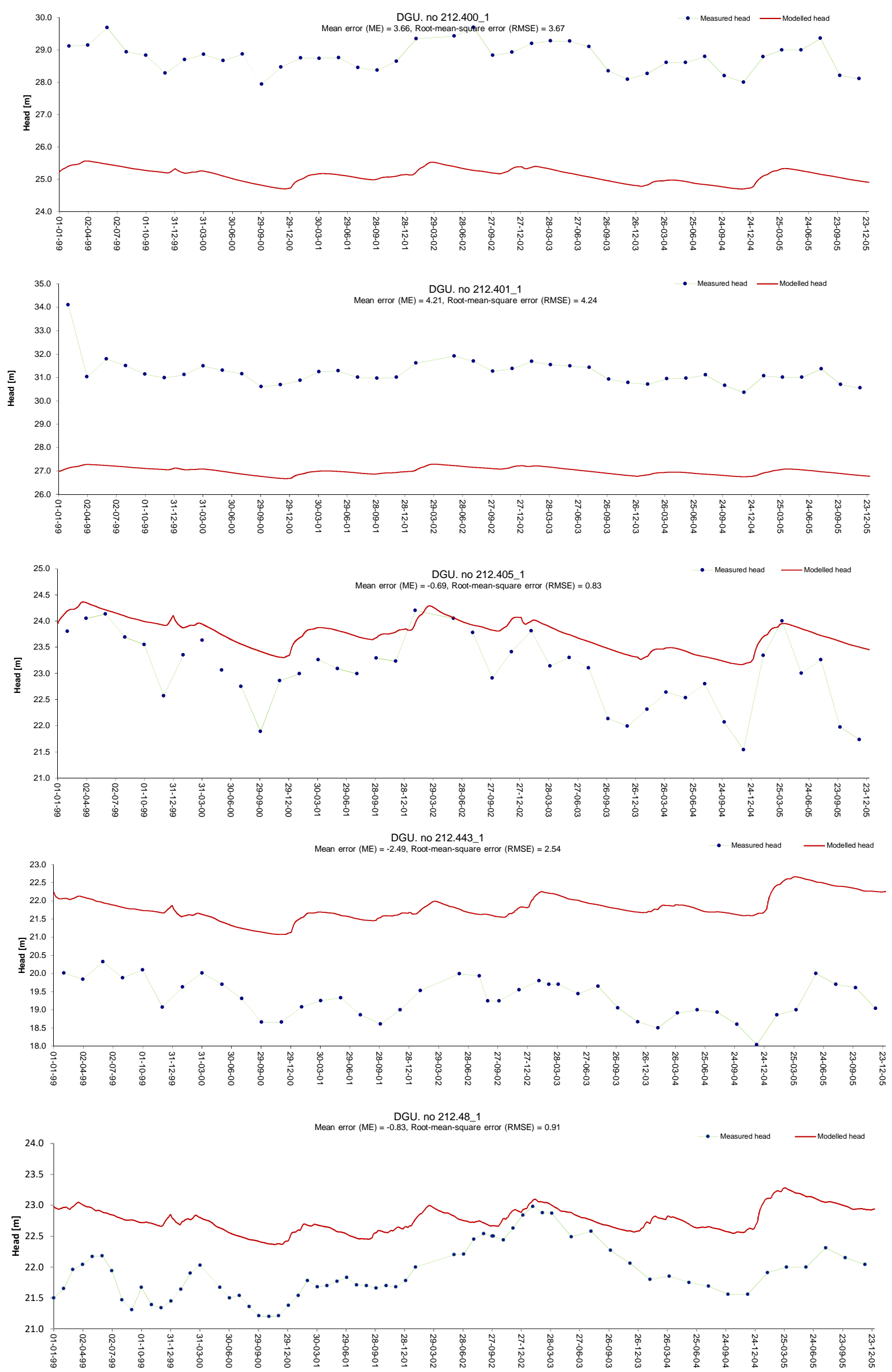

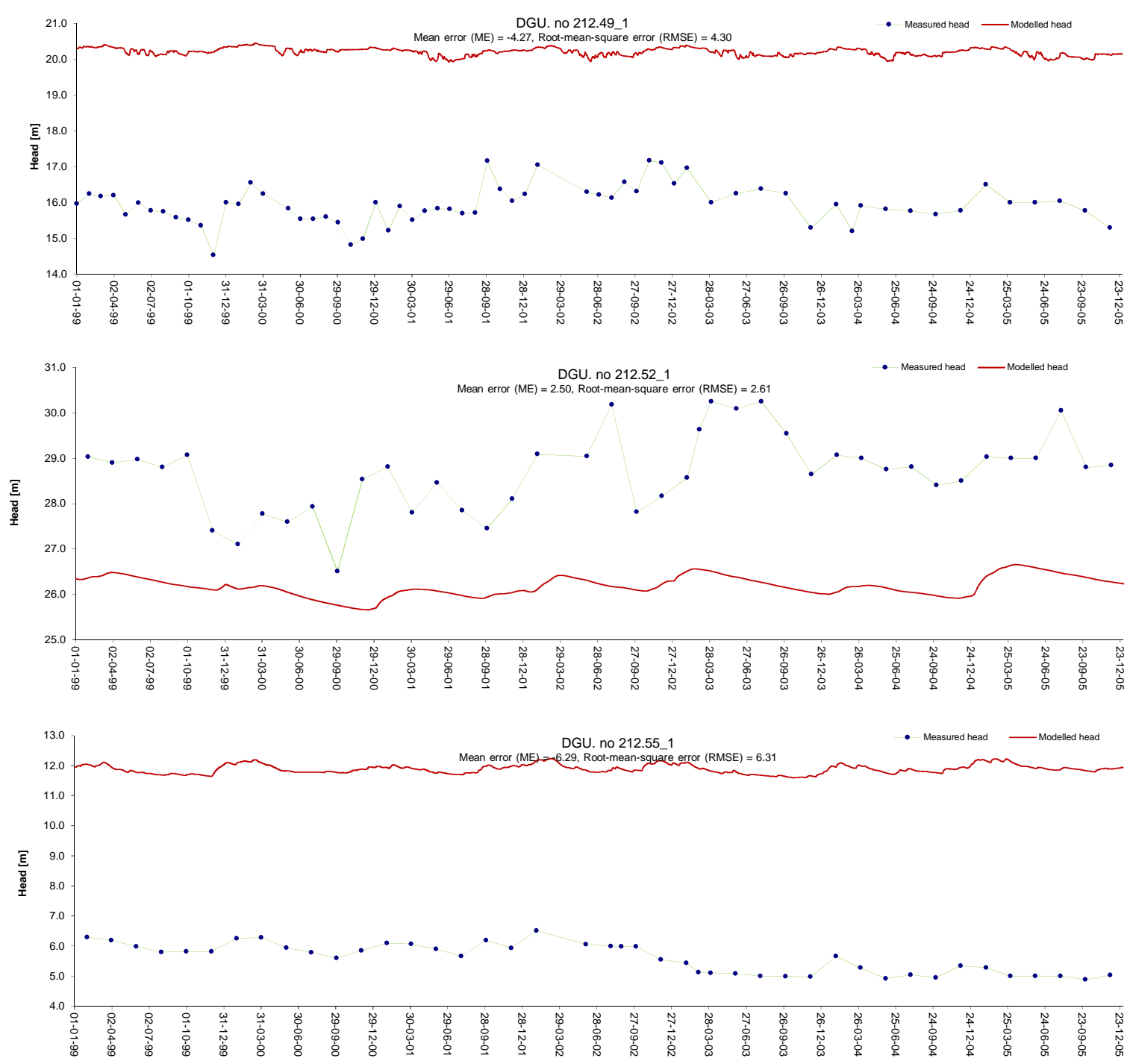
DGU. no 212.56_1
Mean error $(M E)=9.13$, Root-mean-square
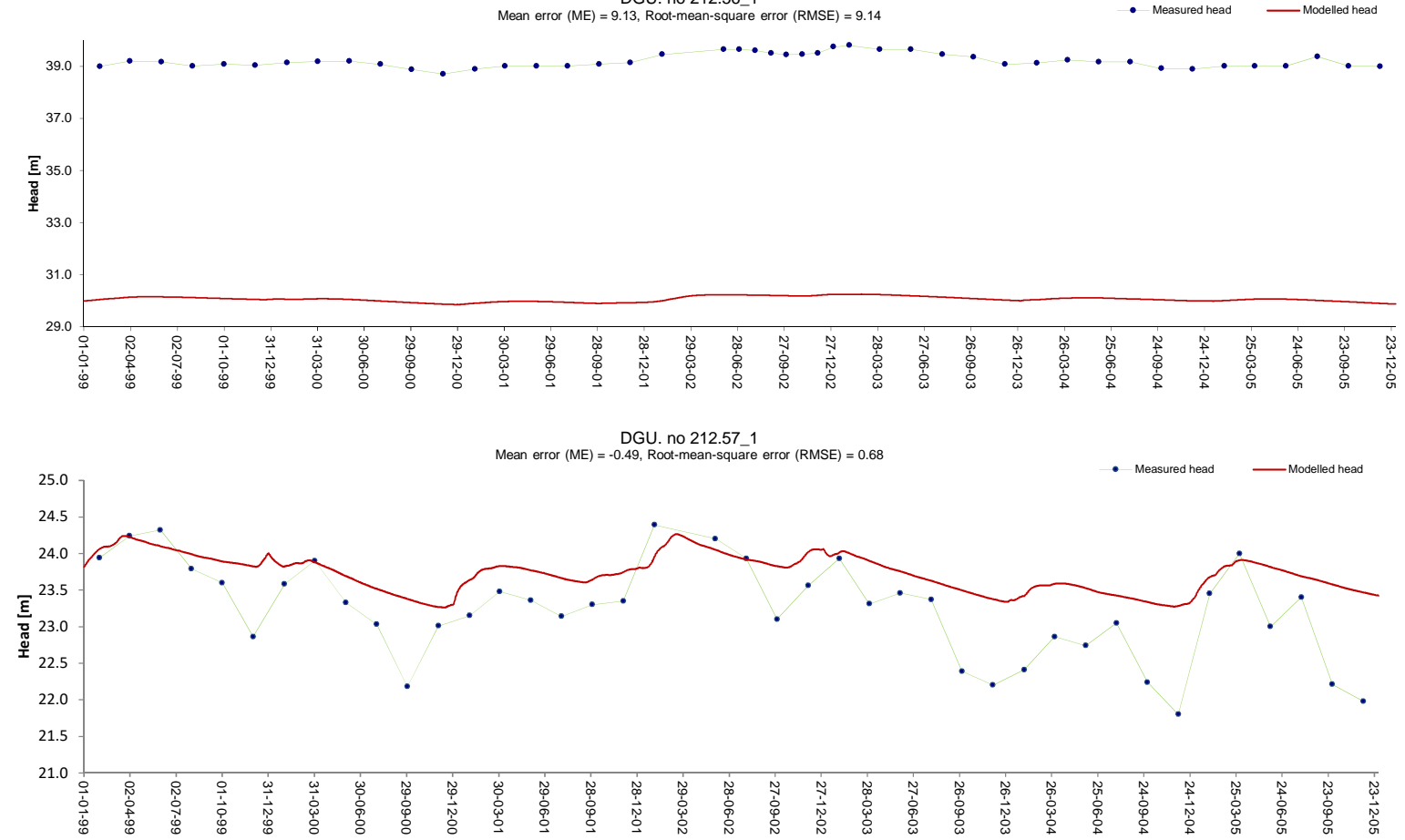

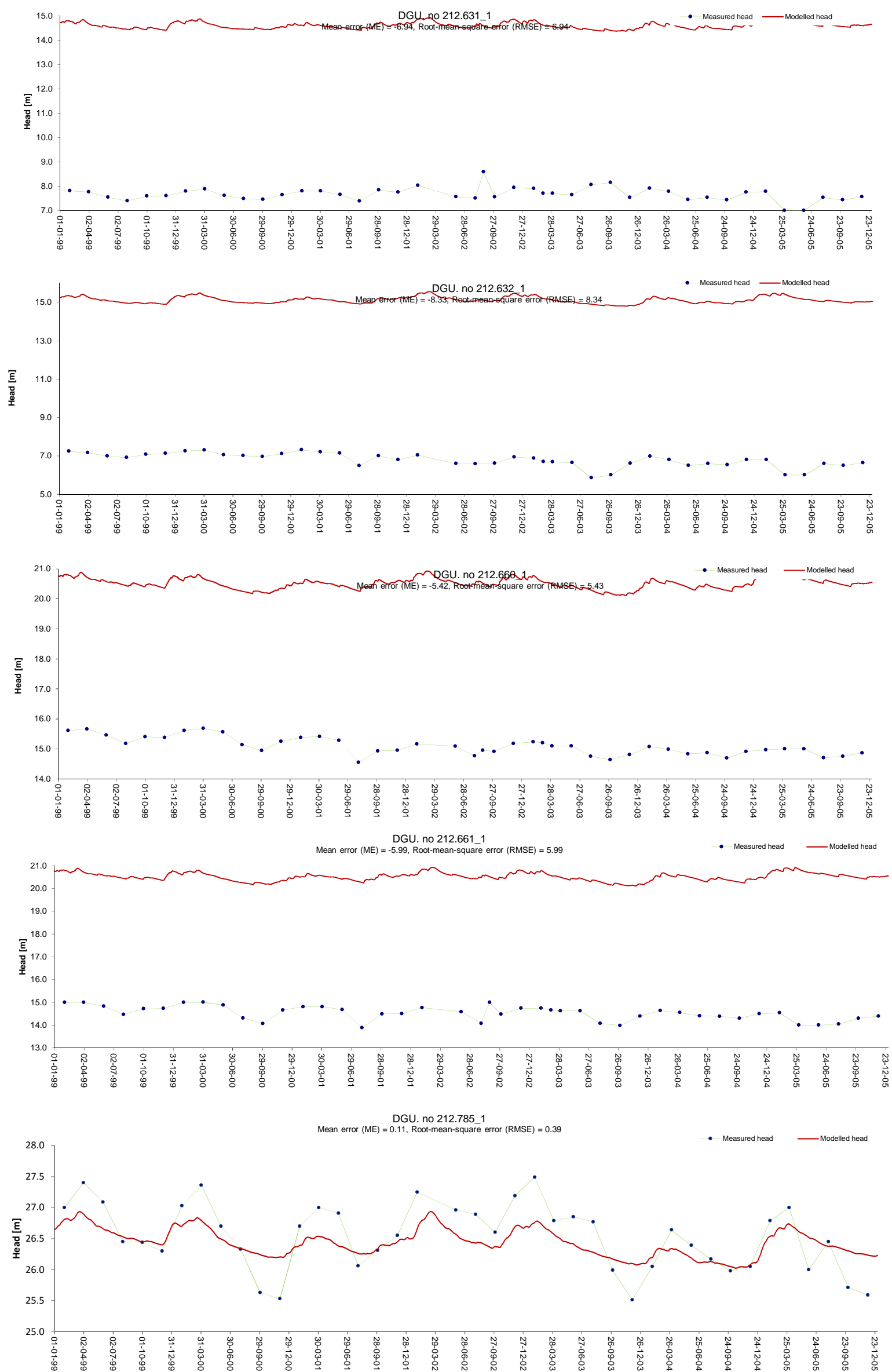

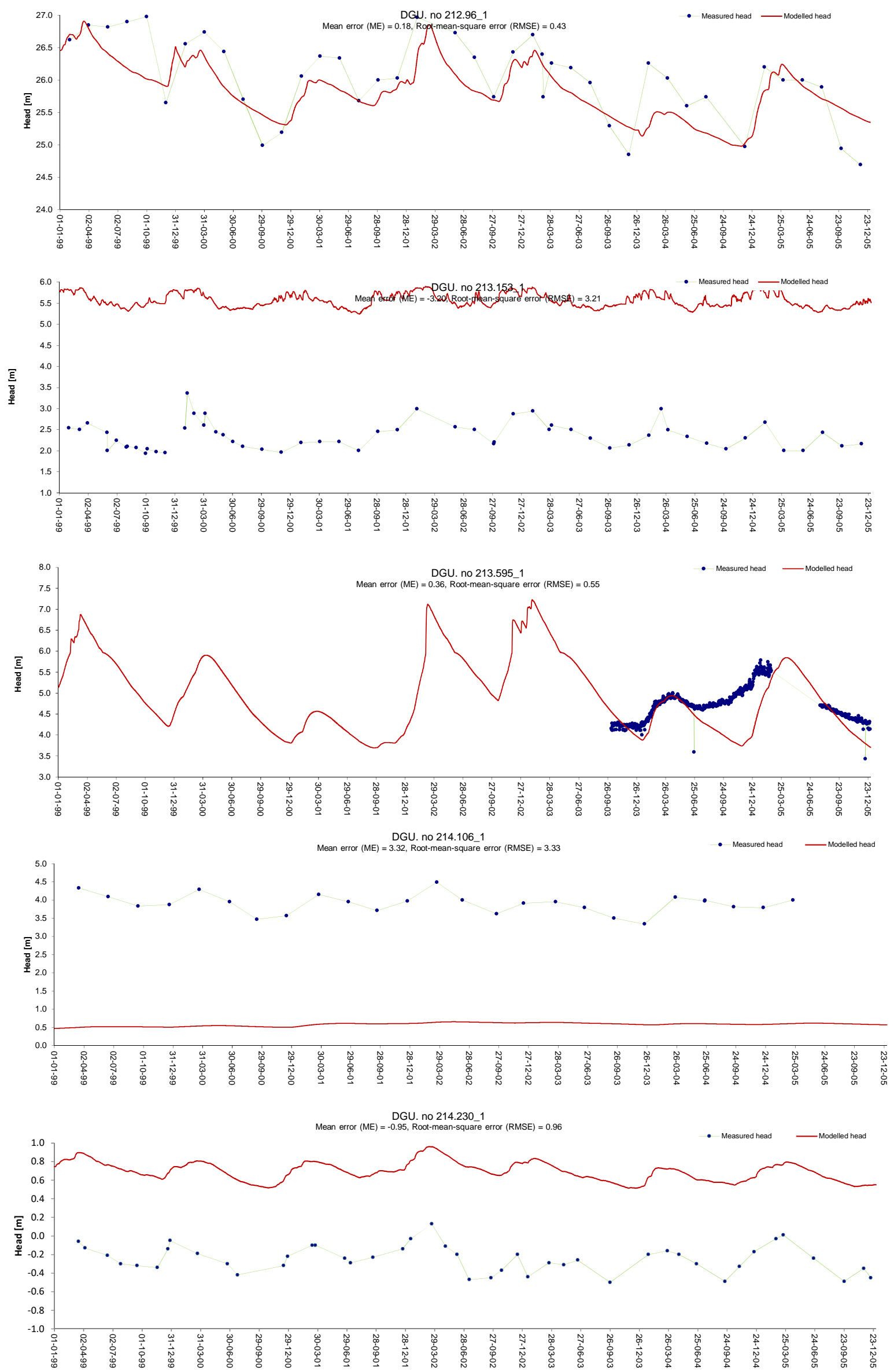

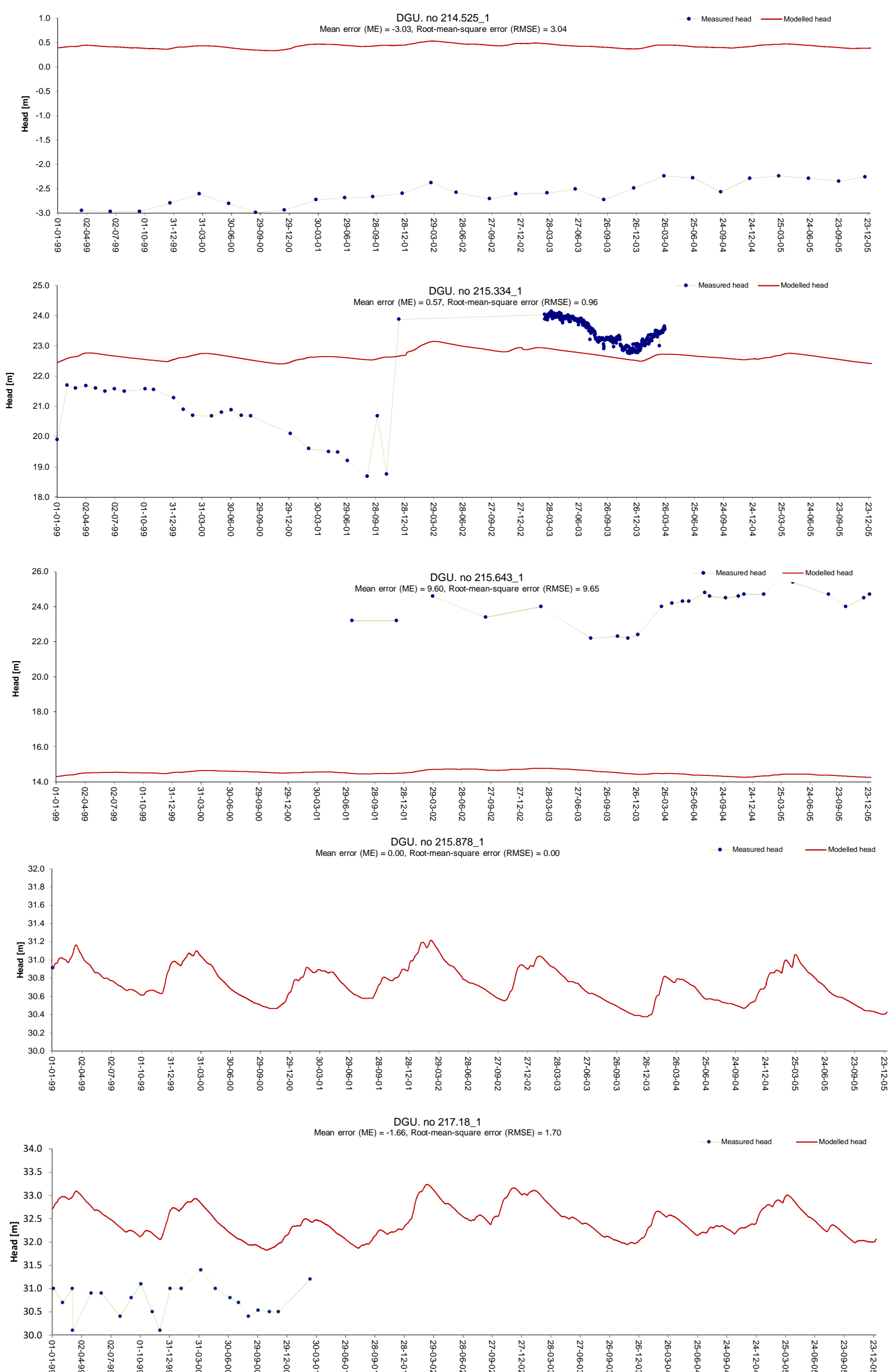

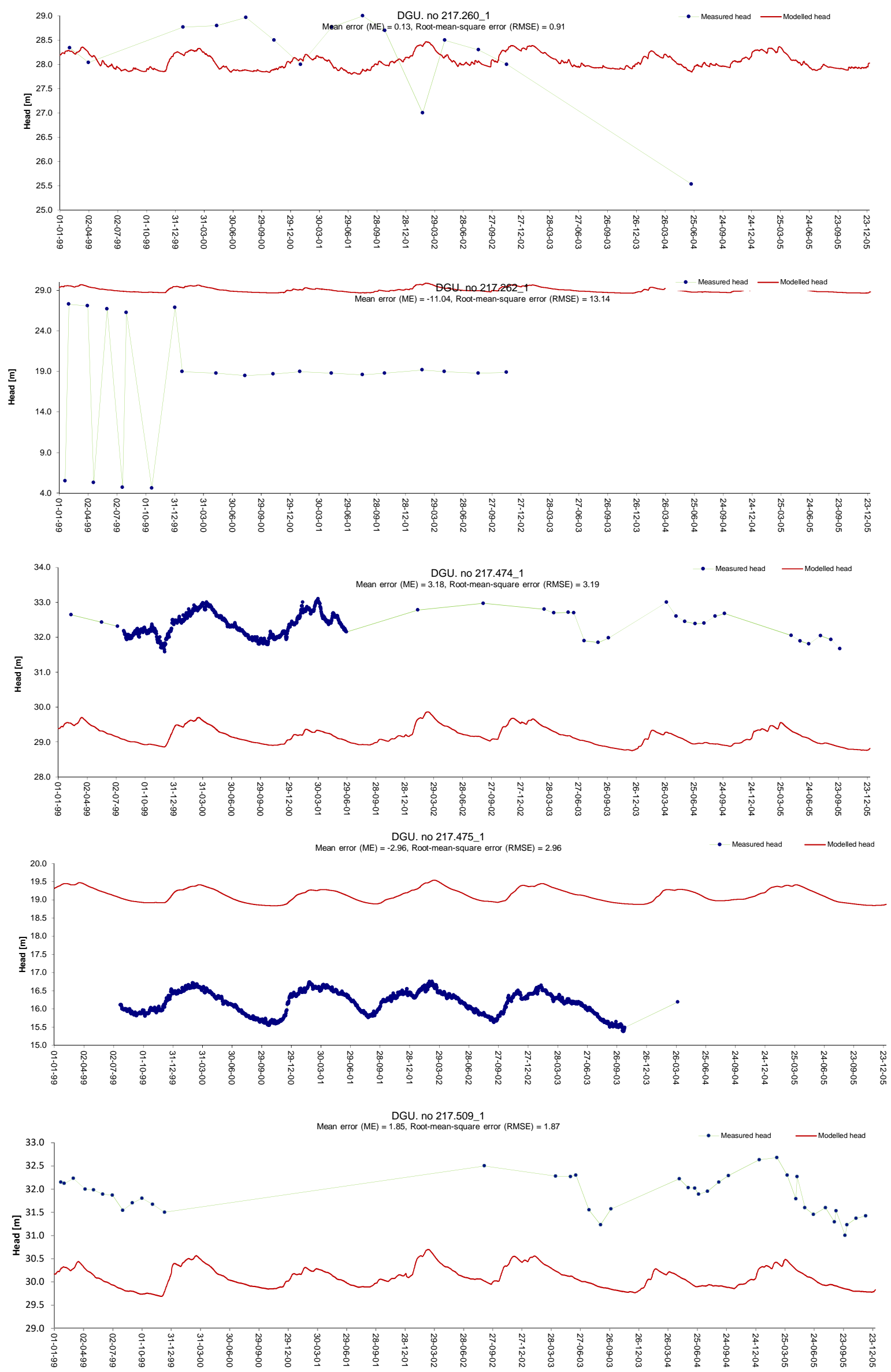

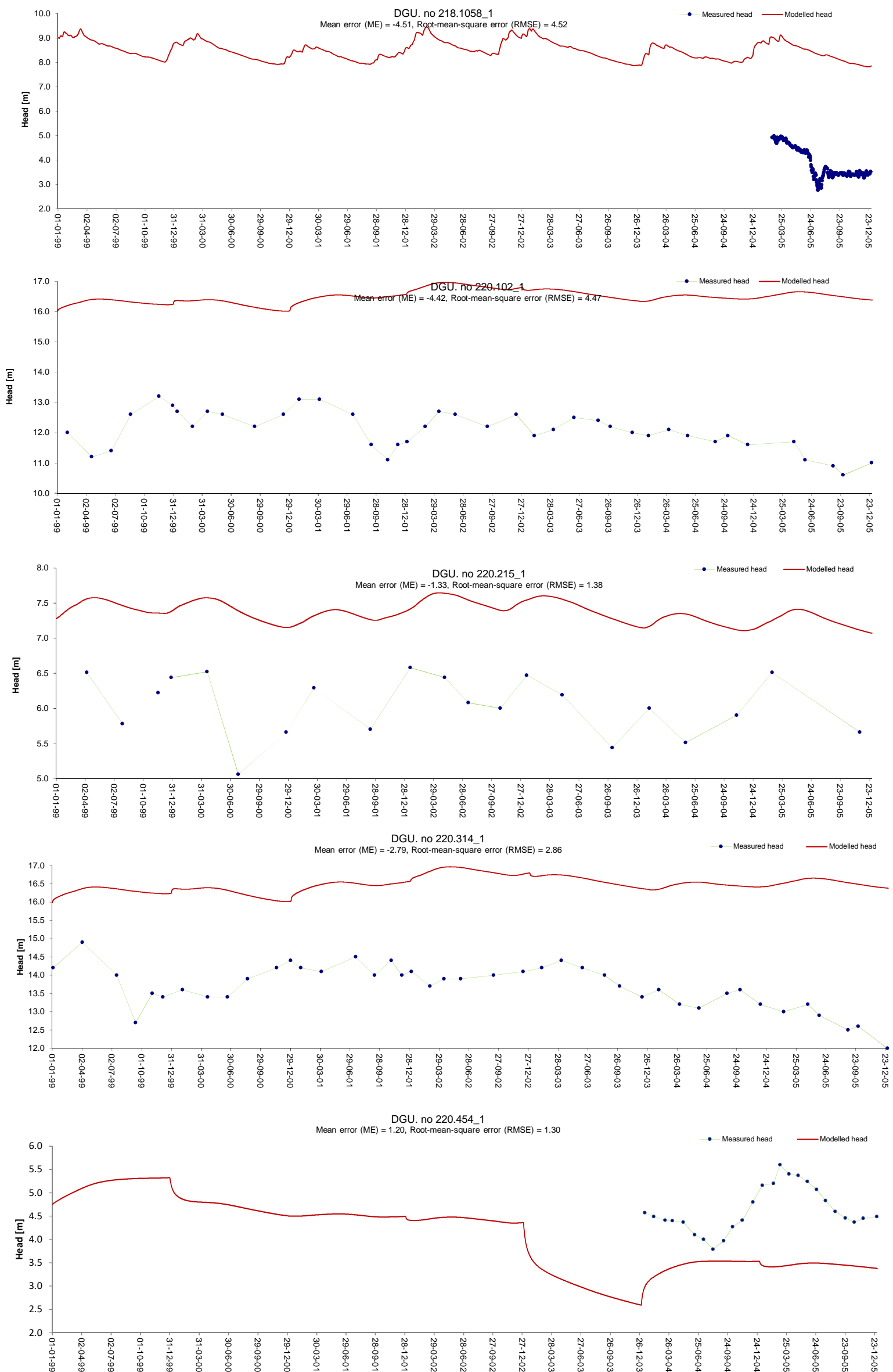

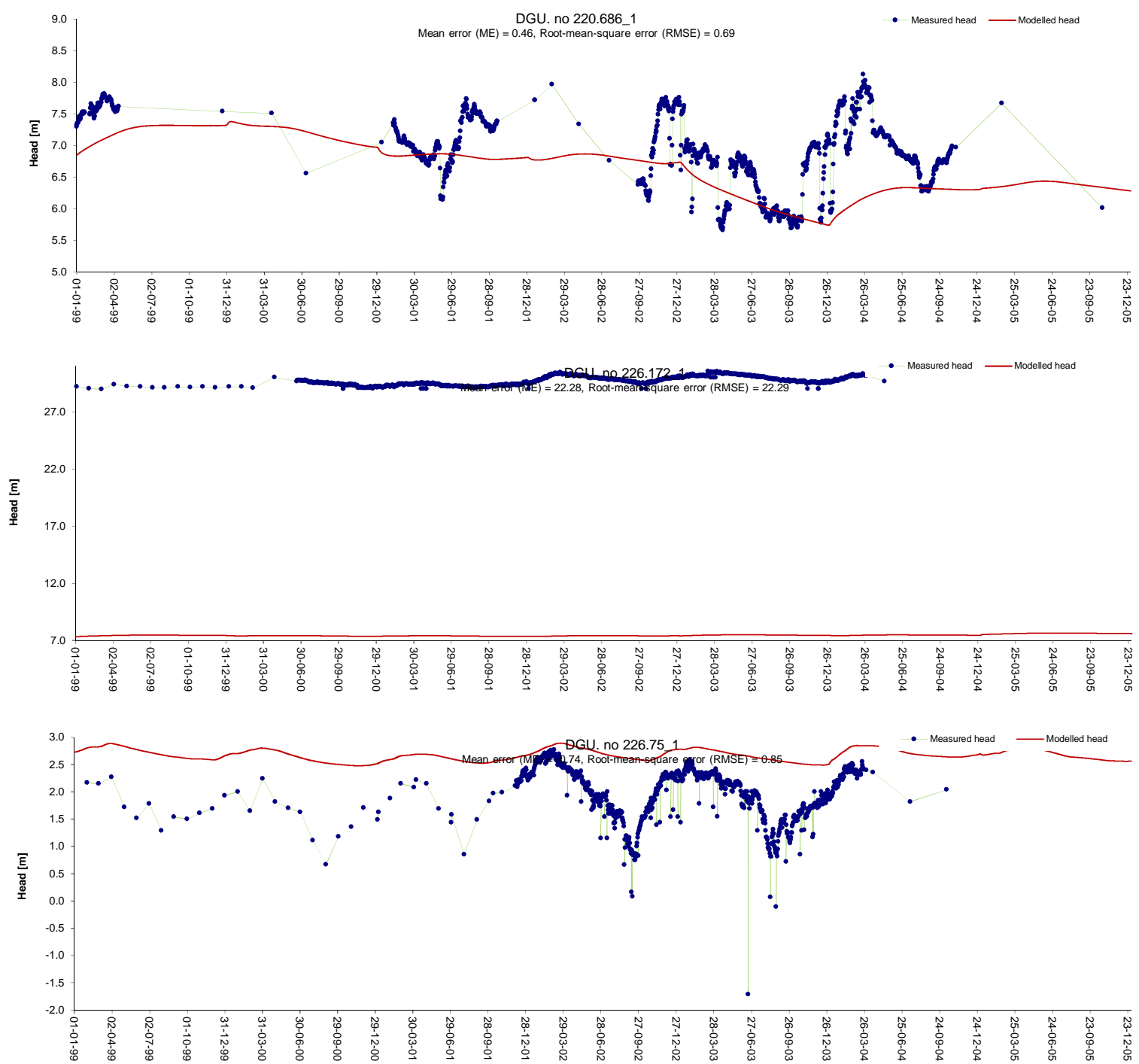

DGU. no 212.335
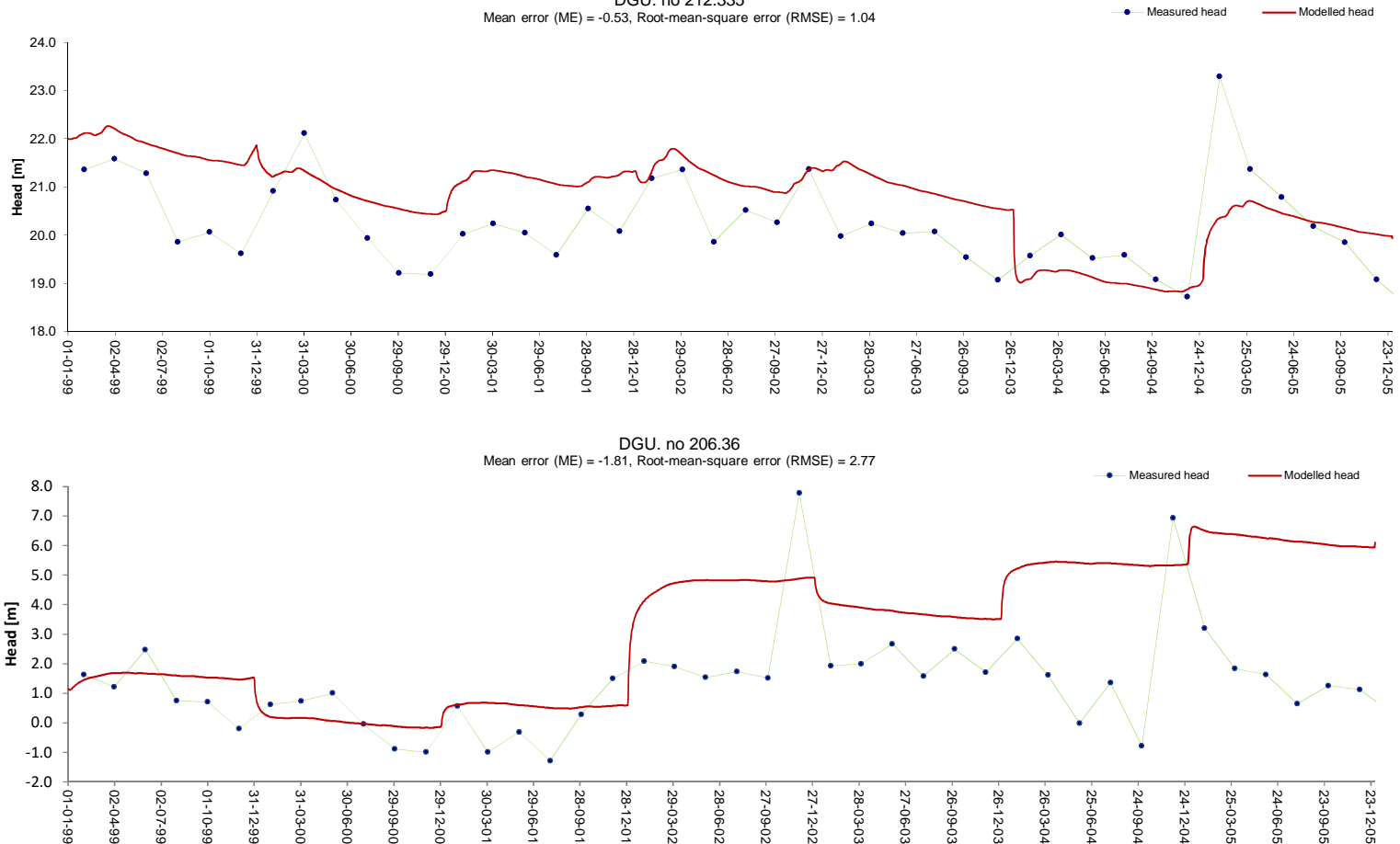

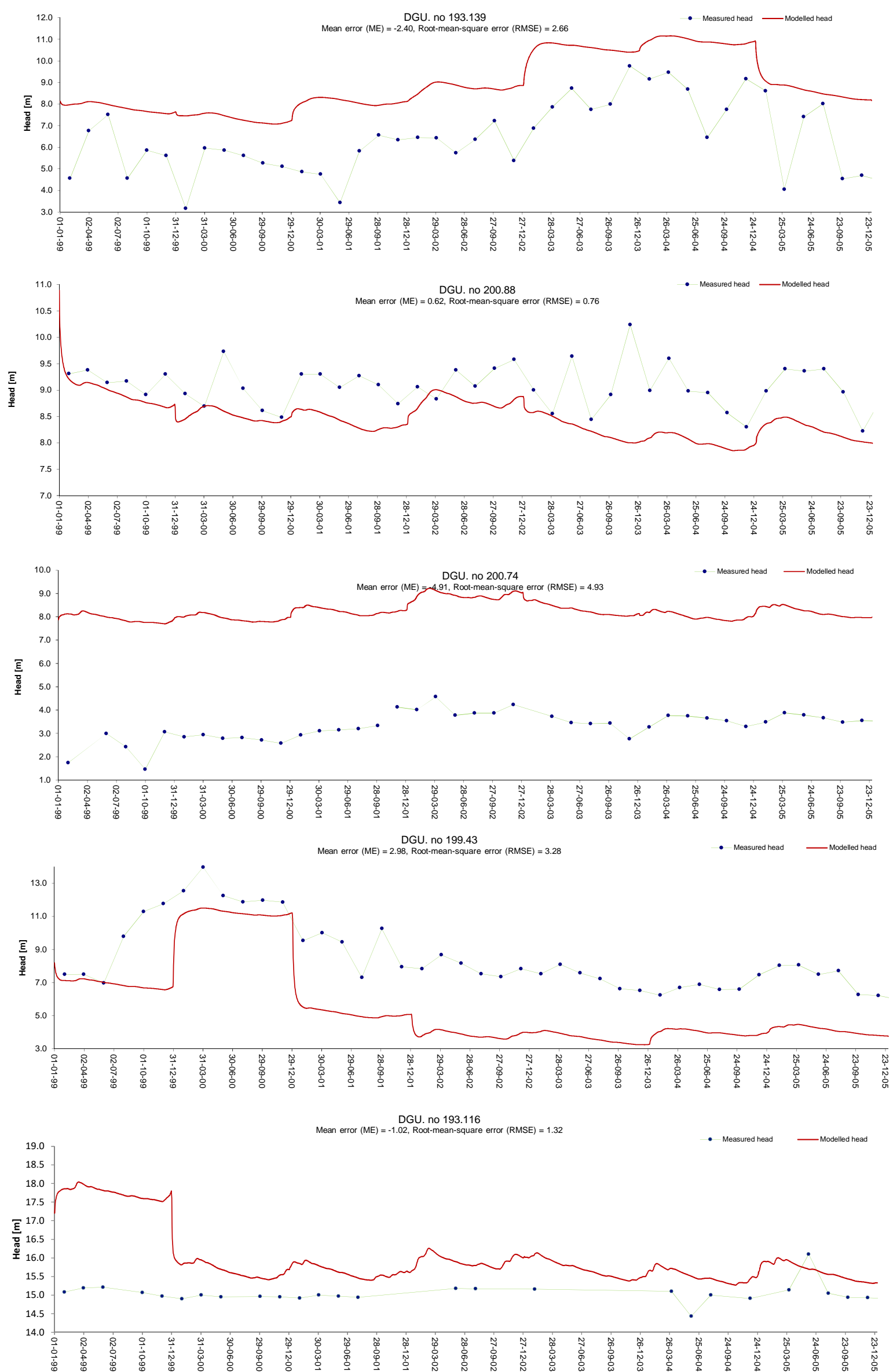

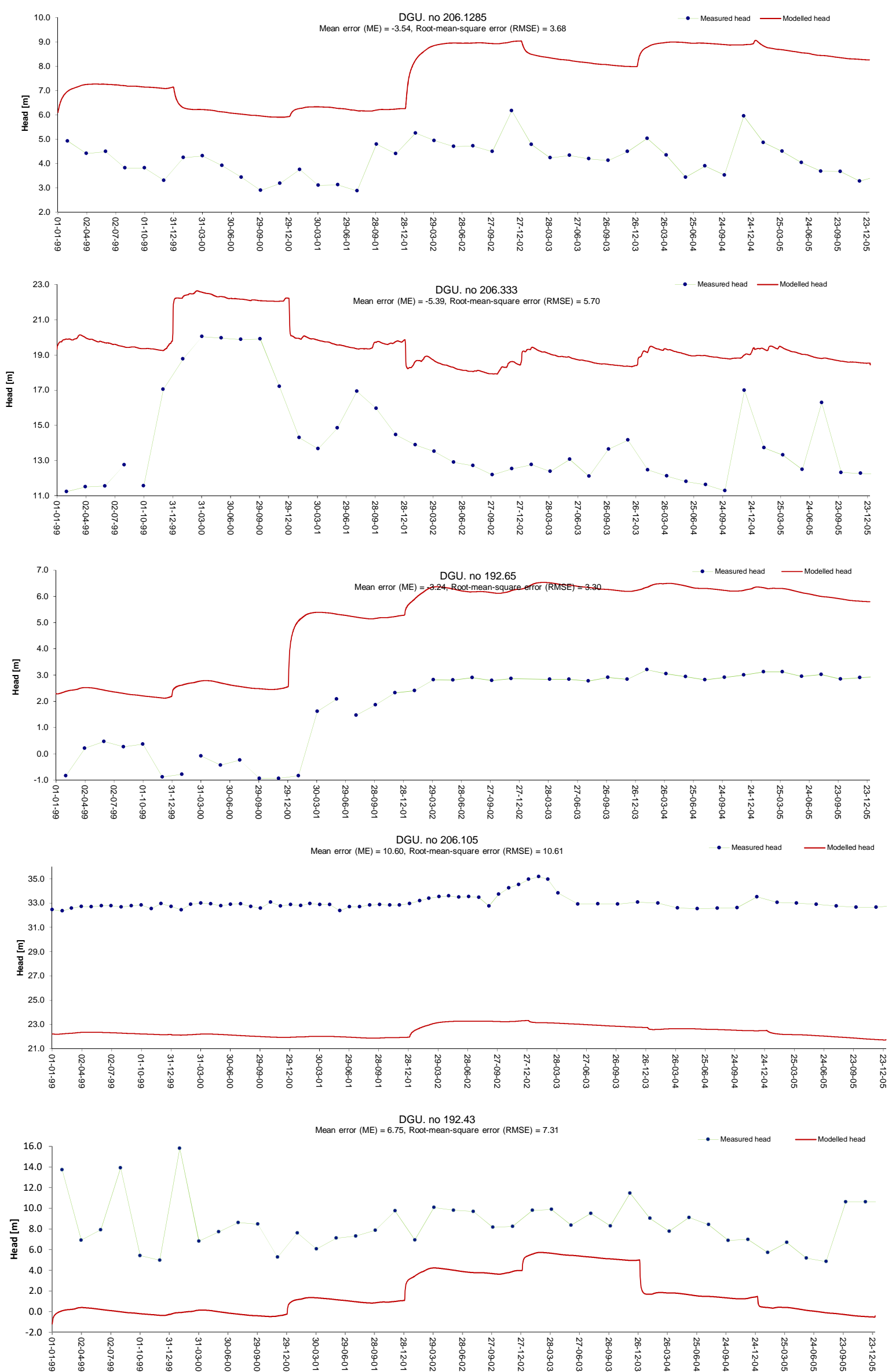

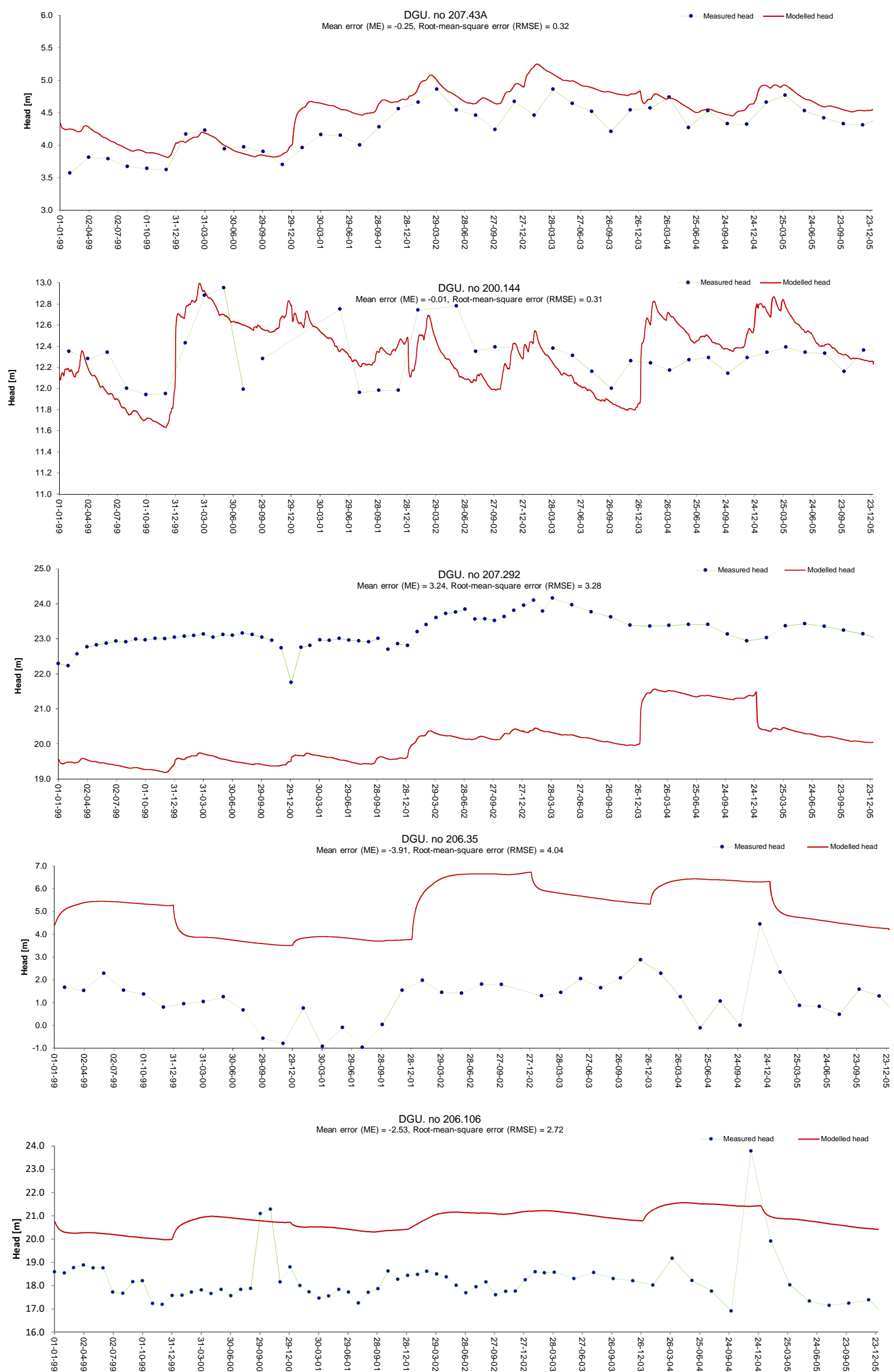

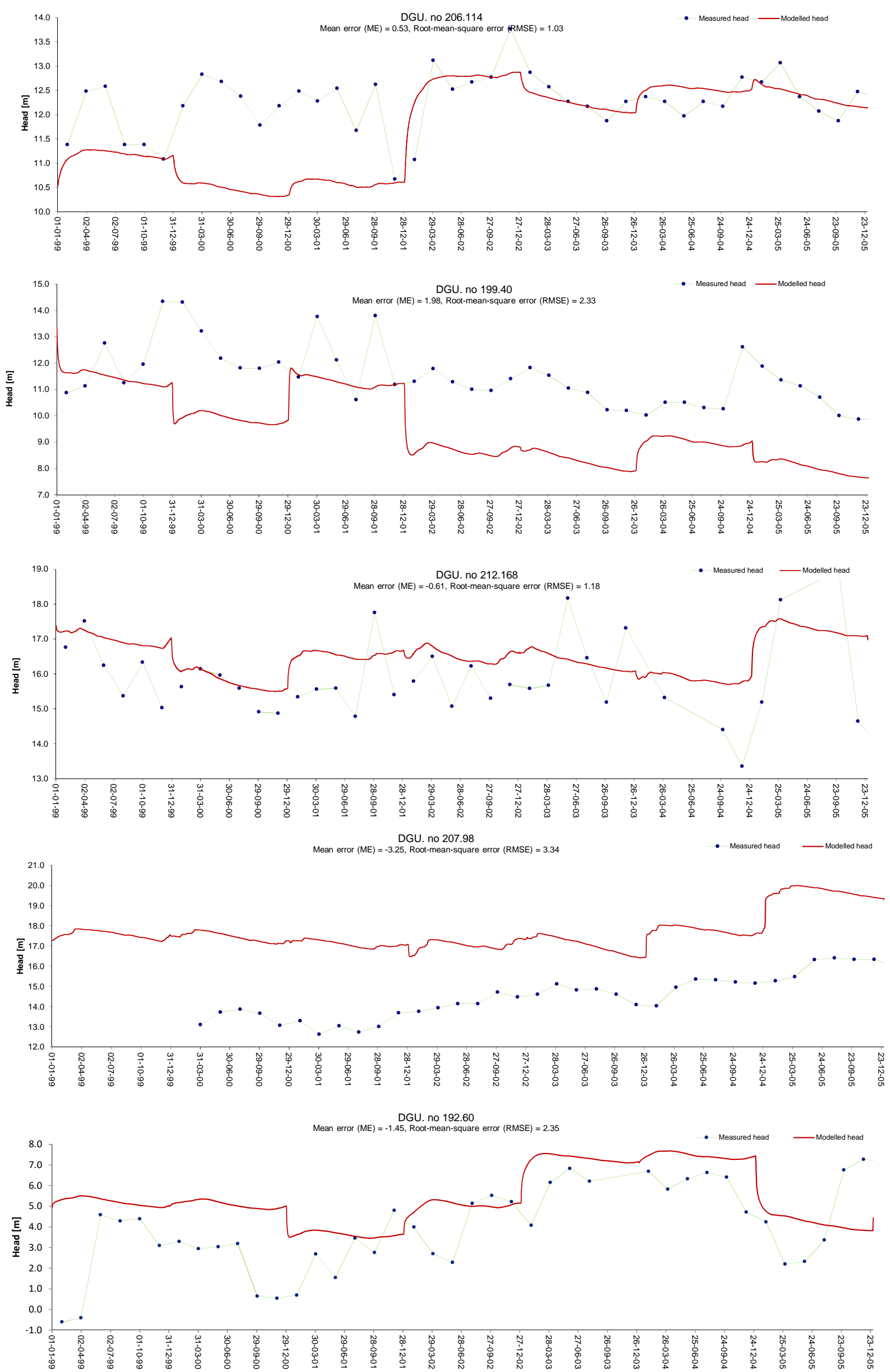

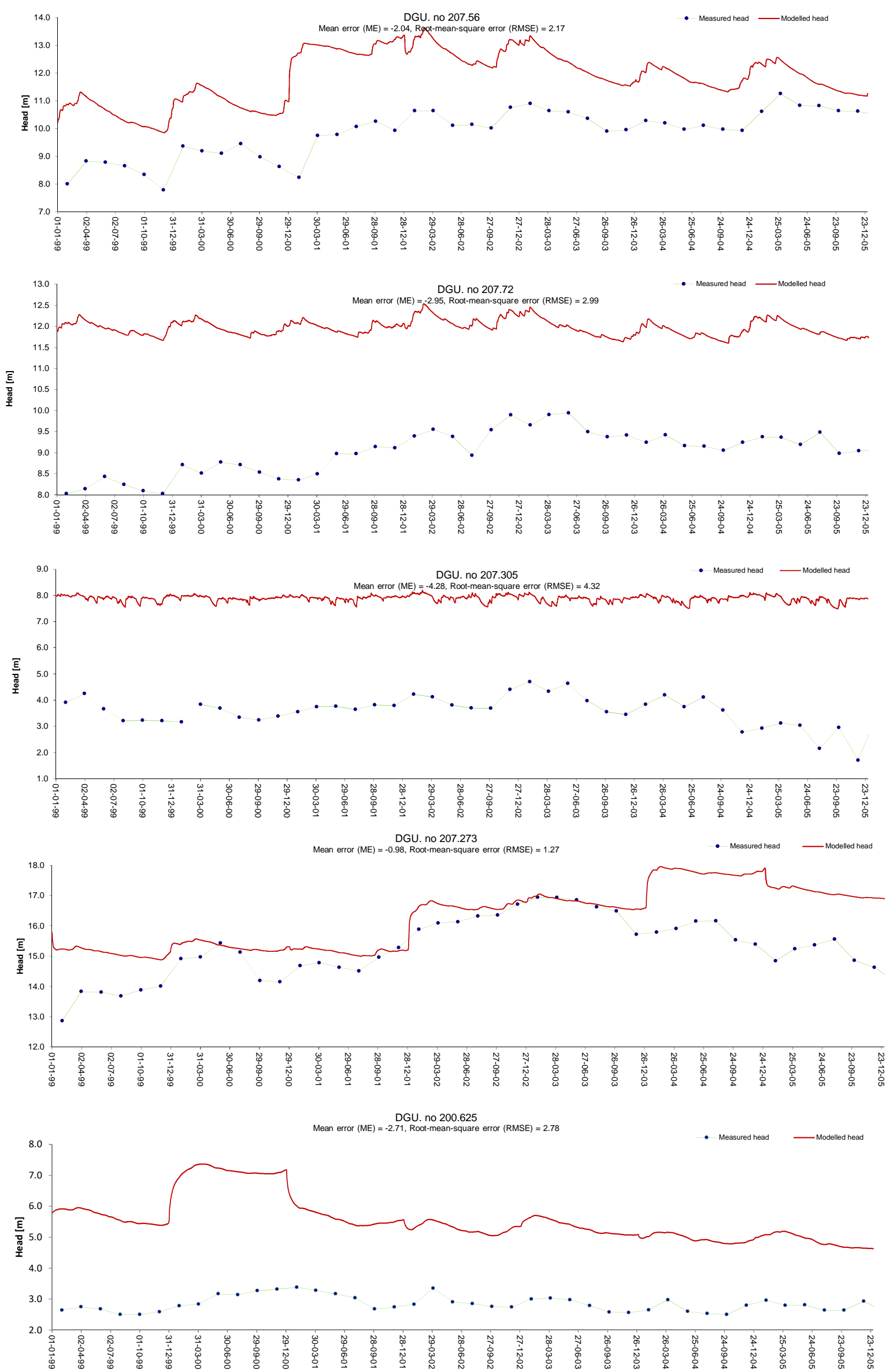


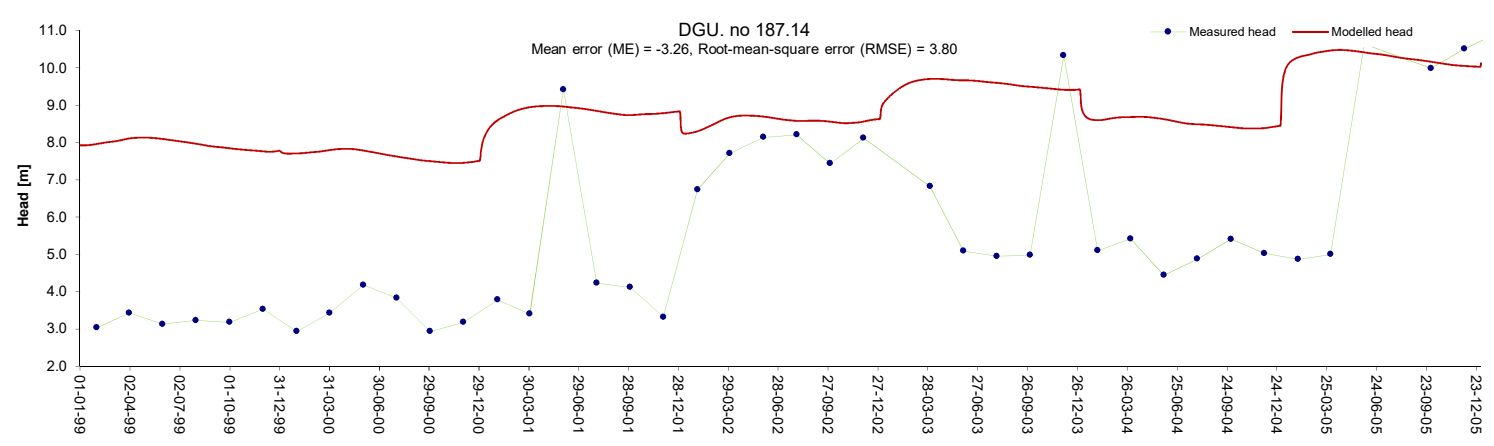


713 We compared the piezometric heads in 22 observation wells (Gejl et al., 2019) with the modelled

714 head in the grid cell for the observation wells in the period 1990-2017 (Figure SI. 3.1). The model is

715 designed to handle water balances on a catchment scale (Klint et al., 2013), therefore representing

716 overall piezometric heads for an area or relative changes in piezometric heads rather than in a point.

717 The piezometric head in a point is complex and can be influenced by local geological structures, and

718 hence we expect some discrepancies between the modelled and observed piezometric heads,

719 magnified further due to an observation well represents a point, where the model represents an

720 area. Another aspect that can lead to discrepancies is that the DK-model is based on average

721 abstractions per year, whereas in reality there can be large variations in actual abstractions at a well

722 field during this time. To improve accuracy, abstraction should be improved or the model further

723 calibrated. With the aim of understanding the broader picture, this model gives a good insight into

724 water balances.

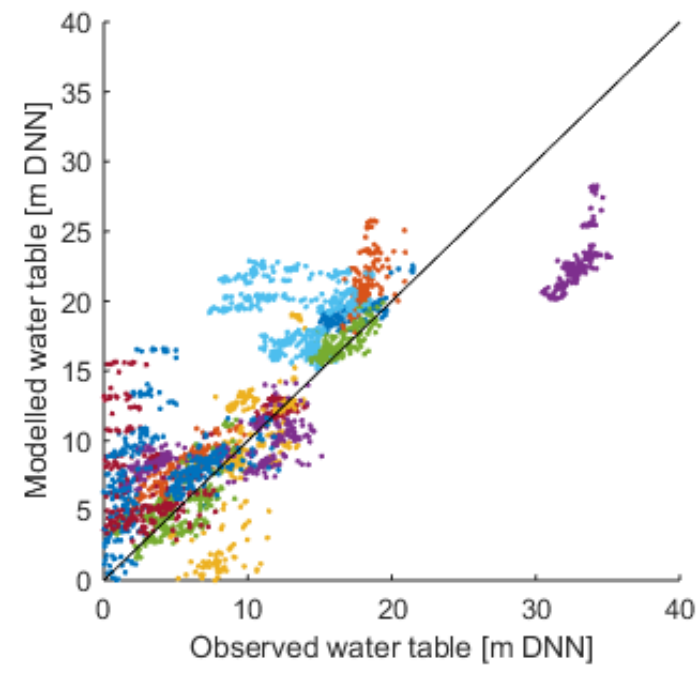

Figure SI. 3.1: Comparison of observed and modelled piezometric heads. The colours in the lower graph

727 represent different well fields. 
$730 A M D_{g w s}$ was evaluated for different scales (SI. Figure SI. 4.1). For the largest scale, namely Zealand as

731 a whole (not included in Figure SI. 4.1), there was still groundwater available that could be used

732 within the definition of sustainable groundwater abstraction. For example, if a drawdown of $3 \mathrm{~m}$

733 were allowed, there was $15.6 \mathrm{~mm} /$ year available on Zealand $\left(137 \mathrm{MmMm}^{3}\right)$. All river basins had

734 water available, ranging from 6 to $48 \mathrm{~mm} / \mathrm{y}$ (Figure SI. 4.1.a). Evaluating for river catchment, 35 out

735 of 204 had a negative $A M D_{\text {GWS }}$ (Figure SI. 4.1.b), which indicates that actual drawdowns pose a risk of

736 changing water quality over time in these river basins (Gejl et al, 2019). The scale of ID15 showed a

737 large variation in $A M D_{G W s}$ around Zealand, with 102 out of 610 ID15 catchment areas with a negative

$738 A M D_{G W s}$ (Figure SI. 4.1.c). Evaluating the smallest scale of $500 \times 500 \mathrm{~m}$, almost half of the grid cells

739 with abstraction had a negative $A M D_{G W s}$ (Figure SI. 4.1.d). 


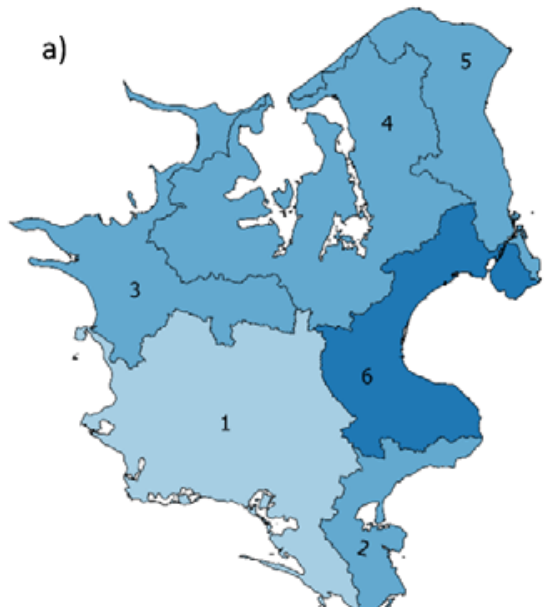

c)
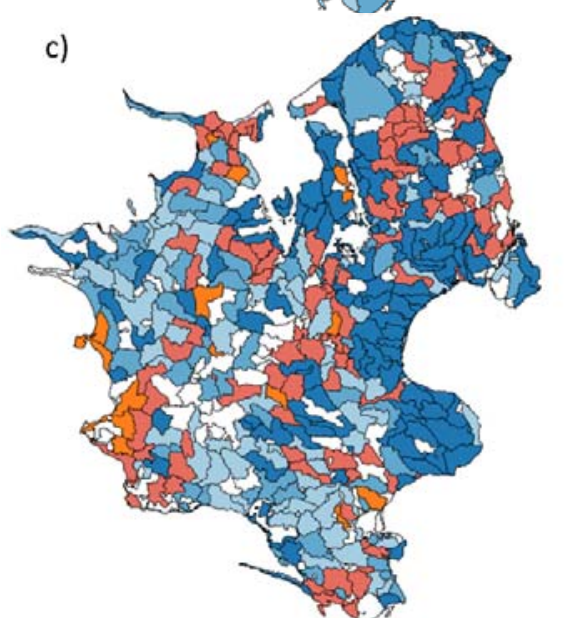
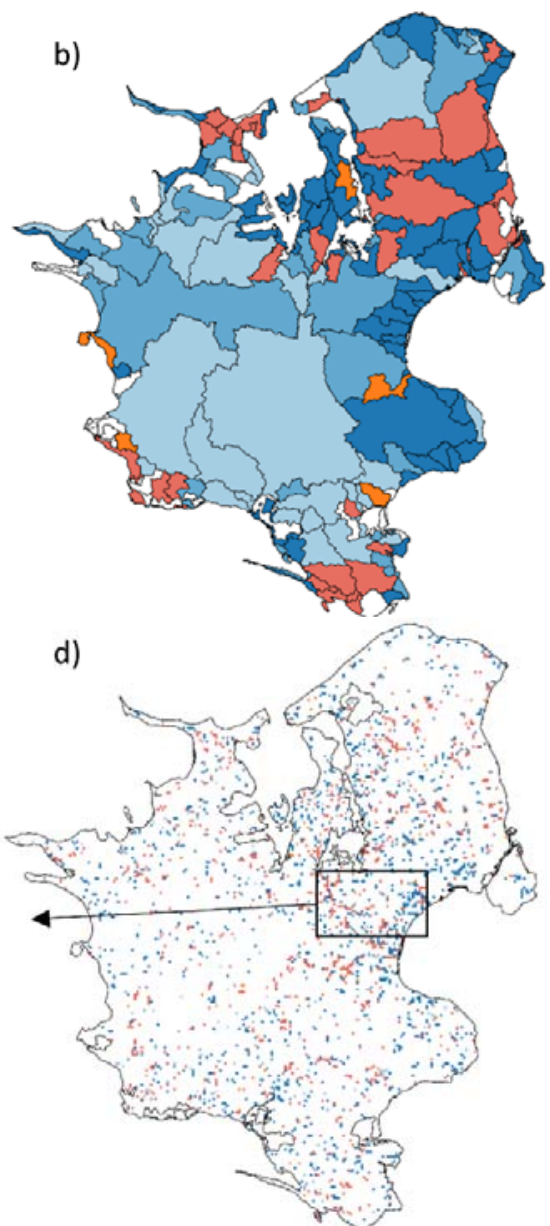

Figure SI. 4.1: $A M D_{G w s}$ for limestone aquifers on Zealand, for four scales: a) river basin, b) river catchments, c) ID15 and d) model grid. 
745 SI. 5: The difference in groundwater abstraction and groundwater recharge between

746 actual abstraction and the scenario of $3 \mathrm{~m}$ drawdown

747
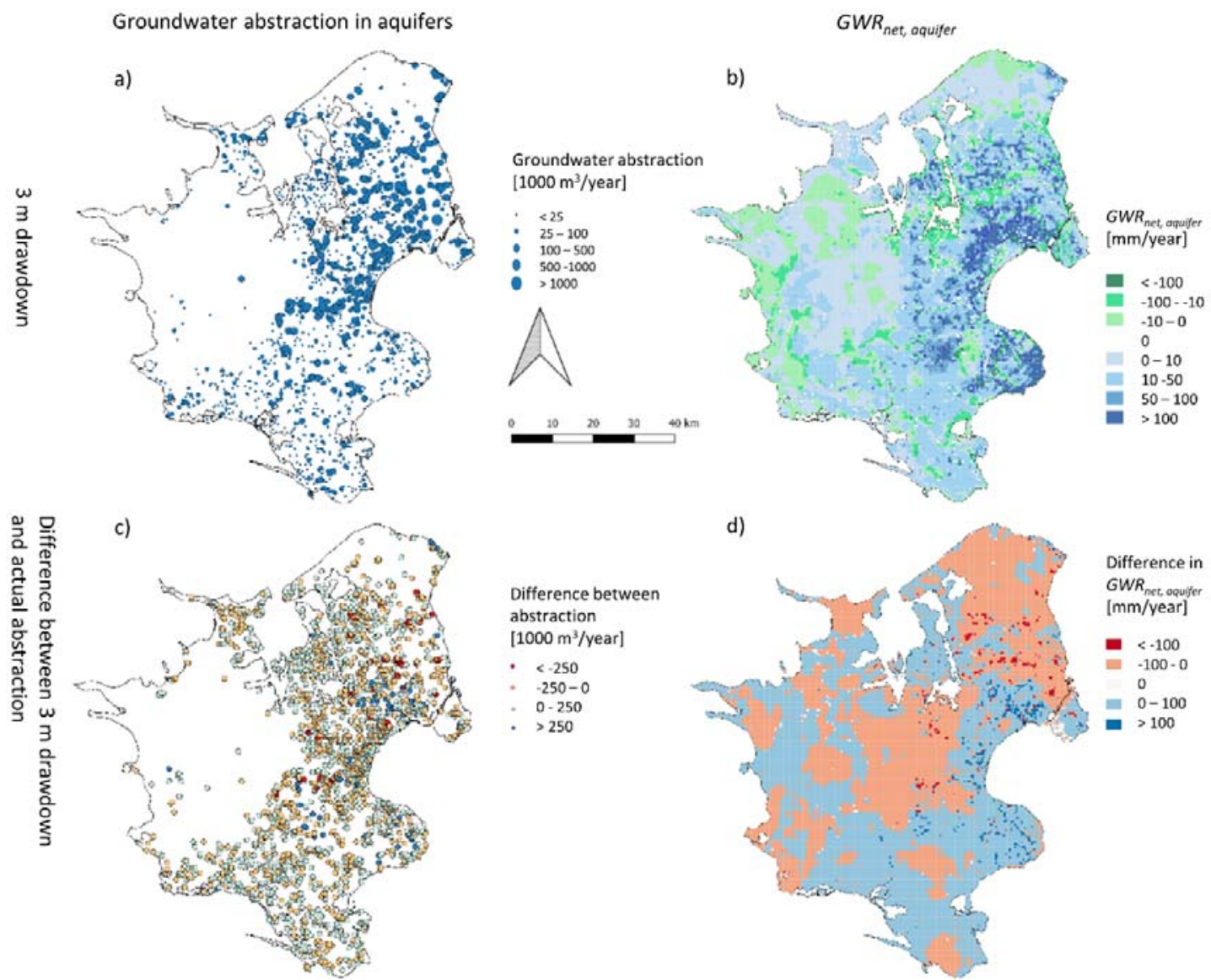

748

Figure SI. 5.1: a) Abstraction and b) GWR net, aquifer for c) Abstraction and d) the difference in GWR net, aquifer

750 between the two scenarios $3 \mathrm{~m}$ drawdown and actual abstraction.

751

752 
Table SI. 6.1: Yearly AGWaRe parameters evaluated for the aquifer with a condition of a maximum $6 \mathrm{~m}$

drawdown for the river basins on Zealand. Actual abstraction refers to average abstractions from 2003 - 2012.

\begin{tabular}{|c|c|c|c|c|c|c|c|}
\hline River Basin no. & $\begin{array}{l}G W R_{\text {aquifer, sus }} \\
\left(\mathrm{Mm}^{3}\right)\end{array}$ & $\begin{array}{l}\mathrm{WU}_{\text {actual }} \\
\left(\mathrm{Mm}^{3}\right)\end{array}$ & $\begin{array}{l}\mathrm{WU}_{\text {sus }} \\
\left(\mathrm{Mm}^{3}\right)\end{array}$ & $\begin{array}{l}E G W R_{w q} \\
\left(\mathrm{Mm}^{3}\right)\end{array}$ & $\begin{array}{l}A M D_{\text {aquifer }} \\
\left(\mathrm{Mm}^{3}\right)\end{array}$ & $\begin{array}{l}\text { AGWaRe } \\
(-)\end{array}$ & $\begin{array}{l}\text { DSC } \\
(-)\end{array}$ \\
\hline 1 & 40.1 & 16.3 & 41.1 & -1.0 & 24.8 & 0.8 & 1.7 \\
\hline 2 & 20.4 & 2.7 & 14.8 & 5.6 & 12.1 & 1.7 & 1.2 \\
\hline 3 & 3.6 & 1.0 & 3.3 & 0.3 & 2.3 & 8.8 & 1.4 \\
\hline 4 & 70.4 & 40.6 & 64.2 & 6.2 & 23.6 & 0.9 & 2.7 \\
\hline 5 & 24.5 & 19.5 & 24.0 & 0.5 & 4.4 & 4.5 & 5.4 \\
\hline 6 & 94.0 & 32.0 & 90.2 & 3.8 & 58.1 & 0.3 & 1.6 \\
\hline
\end{tabular}

757

Table SI. 6.2: Yearly AGWaRe parameters for the aquifer with a condition of a maximum $9 \mathrm{~m}$ drawdown for the river basins on Zealand. Actual abstraction refers to average abstractions from 2003 - 2012.

\begin{tabular}{|c|c|c|c|c|c|c|c|}
\hline River Basin no. & $\begin{array}{l}G W R_{\text {aquifer, sus }} \\
\left(\mathrm{Mm}^{3}\right)\end{array}$ & $\begin{array}{l}\mathbf{W U}_{\text {actual }} \\
\left(\mathrm{Mm}^{3}\right)\end{array}$ & $\begin{array}{l}\mathrm{WU}_{\text {sus }} \\
\left(\mathrm{Mm}^{3}\right)\end{array}$ & $\begin{array}{l}E G W R_{w q} \\
\left(\mathrm{Mm}^{3}\right)\end{array}$ & $\begin{array}{l}A M D_{\text {aquifer }} \\
\left(\mathrm{Mm}^{3}\right)\end{array}$ & $\begin{array}{l}\text { AGWaRe } \\
(-)\end{array}$ & DSC \\
\hline 1 & 54.8 & 16.3 & 57.2 & -2.5 & 41.0 & 0.8 & 1.4 \\
\hline 2 & 24.8 & 2.7 & 20.5 & 4.4 & 17.8 & 2.0 & 1.2 \\
\hline 3 & 4.7 & 1.0 & 4.9 & -0.2 & 3.9 & 9.0 & 1.3 \\
\hline 4 & 93.1 & 40.6 & 89.1 & 4.0 & 48.6 & 0.7 & 1.8 \\
\hline 5 & 33.0 & 19.5 & 35.4 & -2.4 & 15.8 & 2.2 & 2.2 \\
\hline 6 & 117.3 & 32.0 & 113.1 & 4.2 & 81.1 & 0.4 & 1.4 \\
\hline
\end{tabular}


762 DSC was evaluated for different scales (Figure SI. 7.1).
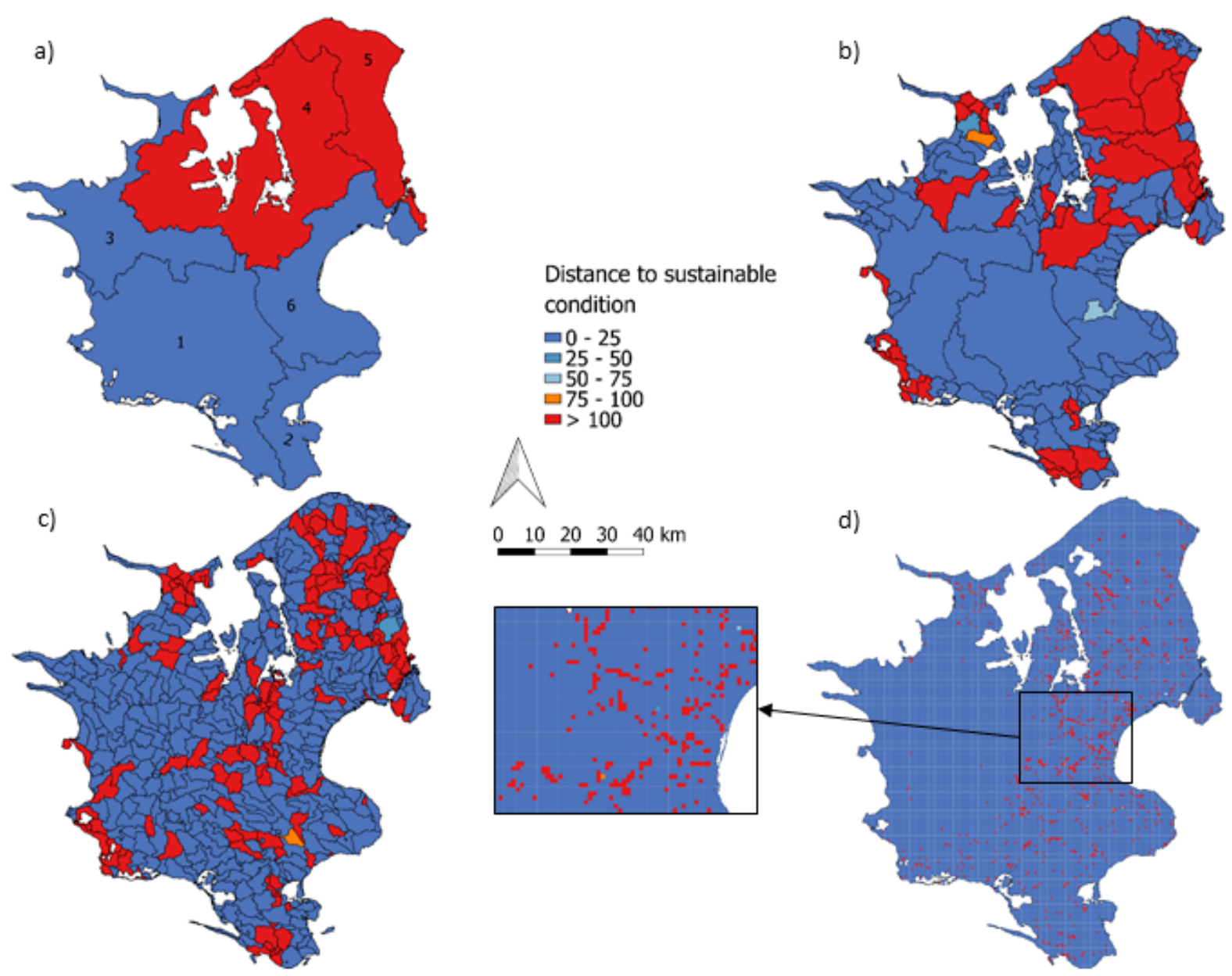

764 Figure SI. 7.1: DSC for limestone aquifers on Zealand, for four scales: a) river basin, b) river catchments, c) ID15 765 and d) model grid. 